UNIVERSIDADE DE SÃO PAULO

FACULDADE DE FILOSOFIA, LETRAS E CIÊNCIAS HUMANAS

DEPARTAMENTO DE LETRAS CLÁSSICAS E VERNÁCULAS

PROGRAMA DE PÓS-GRADUAÇÃO EM LITERATURA

PORTUGUESA

\title{
A Questão da Alienação em O Dia dos Prodígios, de Lídia Jorge
}

Elisangela Fátima Nogueira Godêncio

São Paulo

2007 
UNIVERSIDADE DE SÃO PAULO

FACULDADE DE FILOSOFIA, LETRAS E CIÊNCIAS HUMANAS

DEPARTAMENTO DE LETRAS CLÁSSICAS E VERNÁCULAS

PROGRAMA DE PÓS-GRADUAÇÃO EM LITERATURA

PORTUGUESA

\title{
A Questão da Alienação em O Dia dos Prodígios, de Lídia Jorge
}

\author{
Elisangela Fátima Nogueira Godêncio
}

Orientadora: Prof ${ }^{\mathrm{a}}$. Dr ${ }^{\mathrm{a}}$. Marlise Vaz Bridi.

Dissertação apresentada ao Programa de PósGraduação em Literatura Portuguesa, do Departamento de Letras Clássicas e Vernáculas da Faculdade de Filosofia, Letras e Ciências Humanas da Universidade de São Paulo para obtenção do título de Mestre.

São Paulo 
De tudo ficam três coisas:

A certeza de que estamos sempre começando...

A certeza de que precisamos continuar...

A certeza de que seremos interrompidos antes de terminar...

Portanto, devemos:

Fazer da interrupção um caminho novo...

Da queda, um passo de dança...

Do medo, uma escada...

Do sonho, uma ponte...

Da procura, um encontro... 
À minha querida mãe Luzia, sempre disposta em me ajudar e companheira de todas as horas; ao meu marido e ao meu filho Luís Fernando pela cooperação, paciência e compreensão; às minhas irmãs e irmão por acreditarem em mim. 


\section{Agradecimentos}

A Deus pela graça alcançada; por conduzir a minha vida me ajudando a vencer os obstáculos; e por plantar em meu coração a esperança de que tudo pode dar certo quando se tem garra, determinação e, acima de tudo, fé;

A Prof ${ }^{a}$. Dr ${ }^{\mathrm{a}}$. Marlise Vaz Bridi, minha orientadora, pela presença amiga e estimuladora;

A Prof ${ }^{a}$. Dra ${ }^{\mathrm{a}}$. Maria Helena Peixoto pelo carinho e dedicação prestados à revisão deste trabalho;

A todos os que, compreendendo a necessidade da ausência, permaneceram, fiéis, a espera do retorno. 
"Saber o que fazer é sabedoria; Saber como fazer é bravura; Fazê-lo é virtude."

\author{
Provérbio tibetano
}




\section{RESUMO}

Este estudo parte da idéia de que se pode encontrar, sob o processo de desenvolvimento da consciência, em $O$ Dia dos Prodígios, obra da autora portuguesa Lídia Jorge, referências que remetem à maneira pela qual esta consciência se constitui nos habitantes de Vilamaninhos, cidade fictícia em que se inscreve a ação no romance. O objetivo desta pesquisa consiste em verificar o estado de consciência dos habitantes dessa aldeia e a dinâmica da passagem desse nível precário para outro, mais elevado, nas personagens femininas Branca Volante e Carminha Parda e na personagem masculina Macário, uma espécie de trovador medieval da aldeia. $\mathrm{O}$ exame leva em conta o confronto da aldeia com os soldados que, na narrativa, são os que se inserem no mundo da cultura e que vão levar à aldeia a notícia da Revolução dos Cravos, fato histórico que serve de pano de fundo para o desenvolvimento da trama. Também são examinadas as relações entre as personagens de Vilamaninhos e, ainda, entre estas e os soldados, a linguagem que utilizam; e a atmosfera mítica que permeia o romance. Além disso, investiga-se o contexto histórico da Revolução dos Cravos, que possibilita compreender o rudimentar nível de consciência dos camponeses em relação ao real, sua desarticulação em relação ao universo cosmopolita e seu conseqüente desencontro consigo mesmo, transformado em um ser esvaziado de sentido. Sendo assim, o fato de se apresentarem com um grau de consciência muito precário mostra a alienação do povo de Vilamaninhos, com relação ao restante da sociedade e instiga reflexões sobre as relações humanas.

Palavras-chave: alienação, mito, sociedade, linguagem, interação. 


\begin{abstract}
The starting point for this study is the supposition that, under the process of consciousness development, in $O$ Dia dos Prodígios, narrative work written by the contemporary Portuguese writer Lídia Jorge, lies a series of references to how the character's state of consciousness is and develops along the story. Thus the purpose of this analysis is to verify the state of consciousness of the inhabitants of Vilamaninhos, a small Portuguese village, as well as the dynamics of the transition from such precarious level to a more developed one, the latter illustrated by the female characters of Branca Volante and Carminha Parda, and also by the male character of Macário, who represents a kind of medieval troubadour of the village. This analysis takes into account the confrontation between the inhabitants and the soldiers, who represent the cultured and civilized world (in opposition to the archaic community of Vilamaninhos), and who will tell the villagers the great news about The Oillet Revolution, historic event that fits as a background for the development of the plot. Personal contacts among the villagers and with the outsiders (like the soldiers, for example), their language, the myths supporting their conception of reality are also examined. The socio-historical context of the Oillet Revolution is also investigated, for it helps to understand the villager's rudimentary state of consciousness as to the apprehension of reality, their disconnection with the civilized world and their consequent inner disconnection, which makes them sense-emptied individuals. Thereby, such rudimentary level of consciousness shows the villager's alienation relatively to the rest of society, and the study of this social situation instigates reflections about human relations.
\end{abstract}

Keywords: alienation, myth, society, language, interaction. 


\section{SUMÁRIO}

CONSIDERAÇÕES PRELIMINARES .................................................................... 10

CAPÍTULO I: A Obra em seu Contexto......................................................................17

CAPÍTULO II: As Manifestações da Consciência..............................................................34

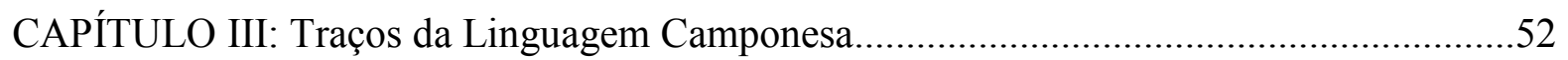

CAPÍTULO IV: O Círculo Mágico de Vilamaninhos....................................................64

CAPÍTULO V: Os Gestos Ritualísticos em O Dia dos Prodígios........................................83

CONCLUSÃO

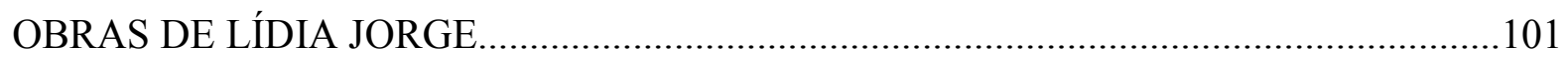

OBRAS SOBRE A LÍDIA JORGE......................................................................... 102

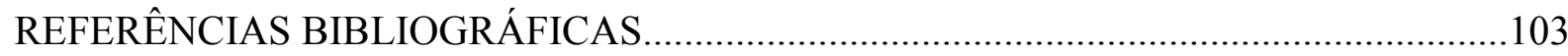

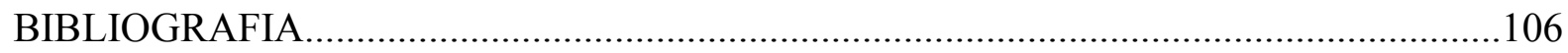




\section{CONSIDERAÇÕES PRELIMINARES}

Na produção literária do período posterior à Revolução dos Cravos, é possível reconhecer uma preocupação não só com a (re)descoberta da História de Portugal, mas também com a sua (re)escrita no domínio do ficcional, o que veio possibilitar a dinamização do diálogo entre os discursos histórico e ficcional. Romances de autores como José Saramago, José Cardoso Pires, Teolinda Gersão, Almeida Faria, Agustina Bessa-Luís, António Lobo Antunes, apenas para mencionar alguns nomes, comprovam as novas tendências que a Literatura Portuguesa Contemporânea passou a seguir após a revolução.

Neste panorama vasto de textos e de preocupações, Lídia Jorge publica, em 1982, a sua primeira obra, O Dia dos Prodígios. Desde então, ela é considerada pela crítica como uma das grandes personalidades da Literatura Portuguesa Contemporânea. Suas obras são, hoje, de destacável importância em todo o mundo, tanto que, por elas, à autora foram conferidas diversas premiações.

Em O Dia dos Prodígios, objeto deste estudo, o fato histórico da Revolução dos Cravos serve como pano de fundo para o desenvolvimento da ação. O confronto entre o espaço da civilização, o das grandes metrópoles - particularmente de Lisboa, onde foi deflagrada a Revolução - e o das pequenas províncias, particularmente das redondezas de Faro, no Algarve, cenário da ação narrada, confere destaque às seqüelas legadas a essas populações periféricas ao longo da história de Portugal e, mais especificamente, ao longo do século XX, período predominantemente tomado pela ditadura de Salazar. 
$\mathrm{Na}$ verdade, esse pode ser considerado como o tema predominante de O Dia dos Prodígios. A intriga transcorre no período de um dia - um dia de prodígios - em que, simultaneamente, ocorrem dois eventos, sendo um deles um evento sobrenatural: uma cobra que os habitantes encontram e que, ao tentarem matar, transforma-se numa cobra voadora e desaparece sem explicações. O segundo evento é a chegada dos soldados à aldeia para anunciarem a Revolução e, com ela, o fim da ditadura salazarista e das Guerras de Ultramar, que já vinham durando há muito tempo (historicamente, se estenderam de 1961 a 1974).

No entanto, para aquelas mentalidades provincianas era muito mais difícil, se não impossível, atribuir um sentido ao discurso dos oficiais do que crer na realidade da serpente voadora e explicar a razão do seu aparecimento ali. De fato, ao se depararem com os soldados que chegaram à vila para anunciar a revolução, os aldeões achavam que os soldados estavam ali por qualquer outro motivo, menos por causa da revolução. Nos fragmentos abaixo, é possível depreender a discrepância entre essas visões de mundo. No primeiro deles, a concepção de Jesuína e dos vizinhos

Quando Jesuína Palha disse. O que vejo, meu deus? Vem aí um carro. Um carro celestial. Celestial. Olhem todos. Traz os anjos e arcanjos. Oh gente. E São Vicente por piloto... Mas os homens, pondo a mão, e fazendo muito esforço para verem claro o que avançava com tanta majestade, disseram. Menos rápidos e mais lúcidos. Vamos. Vamos ser visitados por seres saídos do céu, e vindos de outras esferas. Onde os séculos têm outra idade. Afastem-se, vizinhos, que esta visão costuma fulminar (JORGE, 1982: 152).

A de Macário:

Mas Macário. Tendo sido último a enxergar, teve a visão exacta. No momento de surpresa ainda tinha os olhos fechados de repetir pela última vez. À espera de ocasião. À espera de ocasião. Isto é um carro de combate (Ibidem).

A dos soldados:

Oh amigos. O soldado falou de novo. Dizendo. Agora. Agora as in jus ti ças vão ser reparadas. O tesouro público distribuído igualmente por todos. Porque nos move um i de al. Perfilhado por muita gente (Ibidem: 154). 
Como os excertos mencionados já ilustraram, ao menos em parte, à obra em estudo atribui-se significativa relevância por sua riqueza lingüística e pela abordagem que se faz da história, da memória e da identidade de um grupo social ficcional que remete, por meio dos traços e semelhanças que apresenta, às aldeias portuguesas, no período histórico anterior à Revolução dos Cravos. A autora, por sua vez, como mulher também representa a nova possibilidade de ação em sociedade, considerando que a produção literária do século XX caracteriza-se também pela presença de escritoras, revelando uma voz feminina como presença ativa na sociedade portuguesa contemporânea.

É igualmente possível notar a nova postura da mulher frente à sociedade e frente à própria mulher, nas ações e trajetórias das personagens femininas, bem como no tratamento dado às personagens masculinas, vistas em interação com as mulheres no contexto social de Vilamaninhos, na década de 70.

O romance desenvolve-se em torno de Vilamaninhos, uma aldeia imaginária da região de Algarve. A comunidade apresenta-se como uma sociedade povoada de parentes, amigos, conhecidos, e isso produz uma proximidade entre os habitantes da vila, mas concomitantemente, um distanciamento em relação àqueles que estão fora daquele círculo mágico delimitado pela povoação. A forma como é descrito o vilarejo sugere não só um primitivismo que lhe é peculiar, mas também um como que enclausuramento, pois "Vista de cima alguém chamaria a Vilamaninhos uma estrela, Vista de baixo, no meio das encruzilhadas, apenas se diria. É uma desmoronação de casas" (JORGE, 1982: 72).

Essa espécie de confinamento em que vivem os habitantes, pelo que se nota, terá efeitos muito negativos, pois não estabelecem contato com o exterior e acabam se restringindo ao que têm ao alcance das mãos. Dominados pelo marasmo, eles inventam o prodígio (o incomum), ainda que inconscientemente, para espantar o tédio e alimentar-se de expectativas de natureza mítica. Trata-se de uma serpente comum que, de repente, alcança a condição de réptil voador e, por extensão, a condição de dragão, desaparecendo no ar. O sumiço da serpente gera no vilarejo uma espera e, concomitantemente, uma esperança de que o réptil voltará para tirá-los da mesmice em que se encontram.

Assim, para aqueles homens sem instrução e com um grau bastante precário de consciência, o fantástico e o inusitado rompem o marasmo cotidiano de Vilamaninhos. De fato, o analfabetismo e o semi-analfabetismo são marcantes na comunidade. Nela, tanto a concepção de 
mundo quanto a linguagem que a enforma são arcaicas, em razão do seu alheamento em relação ao avanço tecnológico, científico ou humano. Em conseqüência disso, parece que os vilamaninhenses encontram-se tolhidos em suas possibilidades de desenvolvimento intelectual e crítico e não possuem nenhuma consciência de si; em alguns casos, embora vivam como pares como Pássaro e Branca Volante, José Jorge Júnior e Esperança Teresa - não se comunicam, não interagem, não estabelecem nem uma relação com o outro, nem consigo mesmos.

Essa condição de confinamento, pelos danos que causa ao desenvolvimento humano das personagens da aldeia, ganha uma dimensão quase que trágica quando ocorre o confronto com a realidade da civilização, que surge na forma de soldados comprometidos com os ideais da revolução e empenhados em iniciar, ali, o processo de transformação daquelas consciências.

No entanto, esses indivíduos vivem sem conhecer ou compreender os fatores sociais, políticos e culturais que os condicionam e os impulsos íntimos que os levam a agir da maneira como agem. Mantêm-se distantes da realidade que os cerca e, conseqüentemente, alheios ao mundo, o que desencadeia uma perda do sentido das coisas. Na verdade, nesta obra de Lídia Jorge, é o mito que lhes possibilita atribuir sentido às coisas, tal como ocorre entre as sociedades primitivas.

O impasse entre o mundo da cultura - com suas esperanças e expectativas quanto ao bom futuro de Portugal - e o rudimentar nível de consciência dos vilamaninhenses em relação ao real é, ao que parece, o conflito maior da obra, e acompanhar os meandros desse impasse, verificar como ele se evidencia ao longo da narrativa é o que se pretende neste trabalho.

Para isso, alguns aspectos serão analisados. Inicia-se por aquele que se refere à reação que os vilamaninhenses expressam diante de alguns fatos ocorridos durante a narrativa: a chegada dos soldados ao vilarejo quando foram anunciar a revolução; a reação que tiveram diante do episódio da cobra. Centra-se, também, no aspecto que se refere ao comportamento das personagens, para observar como elas se relacionam entre si e como se relacionam com o mundo exterior à vila.

Ainda para verificar como se realiza esse processo do desenvolvimento das consciências no vilarejo, espera-se examinar de que forma o tempo, ali, se constitui, tendo em vista a relevância que a comunidade confere ao passado e ao tempo vivido. Pretende-se, também, observar esse mesmo processo, por meio da linguagem que os aldeões utilizam para estabelecerem a comunicação, pois, observa-se, há uma mutilação da linguagem. Isto se expressa 
na forma como as relações conversacionais são estabelecidas, de maneira truncada dificultando assim a clareza na comunicação.

Sendo de grande relevância o tema do processo de constituição da consciência, tanto individual quanto coletiva, envolvendo, entre outras coisas, a ligação recíproca entre sujeito e objeto, é de interesse destacar, neste romance de Lídia Jorge, os elementos que apontam para essa questão, verificando ainda os seus desdobramentos no texto.

A pertinência de um estudo como este se justifica por possibilitar que se identifique, em um texto literário de ficção, a história oficial, os conceitos e as verdades de um povo. Pode-se chegar ainda aos implícitos do texto, a ponto de notar que não há, entre as personagens da aldeia, liberdade em relação à construção de seu próprio destino, o qual lhe aparece imposto de fora para dentro, à exceção, por exemplo, do que ocorre com a personagem emblemática de Carminha Rosa, que, ao final, assume-se como sujeito do seu próprio futuro.

A fundamentação teórica, nesta pesquisa, está calcada em estudos sobre o conceito de alienação e consciência infeliz, em Hegel, além de outros ligados a essa dialética que promove a inserção do homem no âmbito da cultura e, por extensão, o desenvolvimento do espírito.

Além dos estudos de Hegel, são axiais os trabalhos de Mikhail Bakhtin (2004); e ainda as pesquisas de Cassirer sobre a linguagem e o mito (1972) auxiliam na compreensão das operações do pensamento mítico. Utiliza-se, ainda, para expor os conceitos acerca da composição do tempo na narrativa, Jean Pouillon (1974) e, dentre os brasileiros, Nunes (1995).

Esta pesquisa busca verificar se, de fato, Lídia Jorge incorporou em seu texto o registro desse ensimesmamento das personagens: como o fez e quais mecanismos foram empregados para conseguir esse efeito? Em que momentos do texto isso fica mais evidente? A forma como se comportam os habitantes do vilarejo diante do fato histórico da Revolução de 25 de abril de 1974, e diante dos acontecimentos que se desenvolvem no interior do vilarejo, justifica ou explica o nível precário de consciência daquele grupo? E, finalmente, qual a postura de Lídia Jorge, enquanto autora e mulher, diante dessa realidade de Portugal?

Esta dissertação está dividida em cinco capítulos. No primeiro, A Obra em seu Contexto, focaliza-se o contexto histórico-cultural da época em que a obra está inserida, bem como se apresentam alguns dos seus elementos constitutivos. De fato, a riqueza da obra de Lídia permite estudá-la atentando-se para aspectos históricos: a pós-modernidade, contexto em que o romance foi publicado, a Revolução dos Cravos, fato que permeia a narrativa. Tendo em vista estes 
aspectos, será feita, neste capítulo, uma explanação acerca do romance português contemporâneo, destacando os elementos contidos deste novo figurino estético na obra de Lídia Jorge. E, acerca da Revolução, também será feita uma verificação teórica atrelada ao comportamento dos vilamaninhenses diante da notícia desse movimento revolucionário, pois, sendo a aldeia de Vilamaninhos o espaço retratado, é possível refletir sobre os impactos da Revolução no cotidiano dos aldeões, em sua vida, em seus pensamentos, ações e sentimentos e, ainda, sobre a sua capacidade de intelecção e de reação aos acontecimentos.

Discorre-se, no segundo capítulo, intitulado As Manifestações da Consciência, sobre o conceito de alienação, sob a perspectiva de Hegel, e sobre o desenvolvimento da consciência, a importância da interação social para tal desenvolvimento e, em decorrência, para o desenvolvimento da coletividade. Pretende-se, aqui, fazer um exame dos conceitos que podem auxiliar na compreensão da sociedade de Vilamaninhos e das relações que seus membros estabelecem entre si.

Atrelado a esse conceito e, ainda para uma compreensão mais abrangente do contexto da ação narrada, faz-se, também, uma breve explanação sobre o conceito de educação em Hegel, relacionando-o ao conceito de educação no regime salazarista, uma vez que os seus efeitos podem ser vistos na sociedade de Vilamaninhos.

O terceiro capítulo, Traços da Linguagem Camponesa, concentra-se na compreensão da natureza do vínculo entre a linguagem e o homem, enquanto indivíduo e enquanto coletividade; com a utilização desse suporte teórico, examina-se a linguagem dos habitantes da comunidade, o papel desempenhado pelo mito na leitura que eles fazem do real. Discorre-se ainda sobre a oralidade, que é a forma preponderante de comunicação entre os habitantes do vilarejo.

No capítulo seguinte, O Círculo Mágico de Vilamaninhos, identifica-se, por meio da análise das relações entre espaço, tempo e personagens, a constituição do processo de enclausuramento e de manutenção do pensamento mítico no meio social de Vilamaninhos.

Em Os Gestos Ritualísticos em $\boldsymbol{O}$ Dia dos Prodígios, quinto capítulo, examinam-se os rituais que revelam a concepção de mundo da aldeia. De um lado, é exemplar o episódio da cobra, protagonizado por Jesuína Palha, e que contribui para ilustrar a mentalidade arcaica da comunidade; nesse mesmo episódio estão presentes alguns símbolos que integram o ritual celebrado por sociedades arcaicas no sentido de atualizar o momento de inauguração do mundo. De outro, são examinados os gestos ritualísticos praticados por duas mulheres, Branca Volante e 
Carminha Parda, figuras emblemáticas da promessa de emancipação feminina no período posterior à derrubada do regime salazarista. Os gestos de bordar e limpar, assim, representam, simbolicamente, um movimento de passagem, de ascensão espiritual, a evolução do nível de consciência dessas personagens, evolução que será viabilizada pela inter-relação consciente em relação ao outro (no caso de Branca, com o marido opressor; no caso de Carminha, com a comunidade e, mais especificamente, com o Sargento, cuja crueldade desencadeia sua libertação). Outro gesto ritualístico examinado é a "música" de Macário, que o torna diferenciado e mais evoluído que outros membros da aldeia, acompanhando, em certa medida, o modelo de Orfeu, do mesmo modo que o drama de Carminha liga-se à tragédia de Édipo e a de Branca à de Penélope (todos esses mitos, no entanto, são retomados no sentido inverso: na obra, são parodiados).

Esta leitura analítico-interpretativa de O Dia dos Prodígios pretende contribuir para a compreensão das diferenças socioculturais evidentes em Portugal e das esperanças e expectativas da inteligência portuguesa em relação aos projetos inaugurados com a Revolução dos Cravos. 


\section{CAPÍTULO I}

\section{A OBRA EM SEU CONTEXTO}

Nos anos posteriores ao 25 de abril de 1974, nota-se um grande florescimento do gênero romanesco em Portugal. Há naquele momento algo diferente que paira no ar, no que se refere ao contexto histórico, pois um "fantasma circula entre nós nestes anos 80: o pós-modernismo" (SANTOS, 1988: 7). Nota-se, não só pela data de seu surgimento como escritora, que a escritura de Lídia Jorge está inserida nesta conjuntura sócio-cultural e estética, apresentando, conseqüentemente, elementos que apontam para a pós-modernidade: a "desconstrução" dos níveis microestruturais do romance; a revolução de sua própria estrutura espaço-temporal e do modo como se processa a organização das personagens e do enredo. Em O Dia dos Prodígios, por exemplo, o leitor, já ao folhear as primeiras páginas, tem o seu primeiro momento de estranhamento ao deparar-se com um texto disposto ora em colunas, ora em formatos irregulares. Não param aí as surpresas: a obra é ainda percorrida por vozes simultâneas situadas em espaços diferentes (as duas Carminhas em sua casa; Jesuína Palha e outros habitantes da aldeia em espaço aberto, acabando de enfrentar a cobra voadora etc).

O pós-moderno pode ser considerado como algo fundamentalmente contraditório, pois apresenta traços a apontar não só para o que Hutcheon (1991) chamou de "presença do passado" 
(continuidade), como também para a ruptura de um padrão já estabelecido e definido, pois a conjunção de tradição e ruptura acaba por instigar transformações futuras. A esse respeito, é importante ressaltar que "a presença do passado" na pós-modernidade não representa um retorno nostálgico, mas sim uma reavaliação crítica, uma espécie de diálogo irônico com o passado da arte e da sociedade. No entanto, a ruptura, talvez a principal característica da modernidade, volta a apontar o aspecto moderno da pós-modernidade.

Por se mostrar contraditório e atuar dentro dos próprios sistemas que tenta subverter, o pós-modernismo não pode ser considerado como um novo paradigma, mas serve como marco para o surgimento de algo novo. Mostra-se como um processo ou atividade cultural em andamento e uma estrutura teórica aberta, em constante mutação, com o qual é possível organizar conhecimentos culturais e procedimentos críticos. O debate acerca do próprio termo pósmodernismo começa pelo significado do prefixo "pós”. Essa “posição 'pós' assinala sua dependência e sua independência contraditórias em relação àquilo que a precedeu no tempo e que possibilitou sua existência" (HUTCHEON, 1991: 36).

Assim, parece evidente a relação que se estabelece entre pós-modernidade e modernidade, pois a primeira não caracteriza um rompimento radical nem uma ligação direta com relação à segunda. A pós-modernidade apresenta esses dois aspectos e, concomitantemente, não apresenta nenhum. Isso sugere, inevitavelmente, uma inserção da modernidade na pós-modernidade, mas o relacionamento complexo entre ambas é de conseqüência, diferença e dependência. A pósmodernidade confronta e contesta qualquer rejeição ou recuperação modernista do passado em nome do futuro. Esta sugere "uma reavaliação e um diálogo em relação ao passado à luz do presente" (Ibidem: 39). Desse modo, o passado como referente não é enquadrado nem apagado, mas sim incorporado e modificado, recebendo uma vida e um sentido novo e diferente.

$\mathrm{Na}$ literatura, especificamente no romance, nota-se um contraste. Enquanto os modernos defendem ao máximo a forma e a originalidade, os pós-modernistas lutam pela extinção da forma romance, como no nouveau roman francês, ou então clamam pela paródia, o pastiche e pelo uso de outras formas romanescas: romance histórico, policial, ficção científica, etc. Desse modo, na pós-modernidade, o romance perde aquela característica linear (em que todos os elementos da narrativa, enredo, espaço, tempo, personagem, se encadeiam de forma clara, precisa e seqüencial), tão acentuada pelos modernos, para incorporar uma forma narrativa que bane o enredo, o assunto e a personagem, em uma tentativa de matar o romance enquanto gênero. 
Nesse sentido, a ficção da pós-modernidade "recusa o realismo (o parecer verdadeiro), recusa o enredo com começo, meio e fim, o herói metido em aventuras, o retrato psicológico e social, a mensagem política ou moral" (SANTOS, 1988: 62). Mas, por outro lado, ela procura valorizar os objetos, analisados sob a perspectiva do olhar de alguém que utiliza uma câmera cinematográfica. A narrativa pós-moderna se vale, simultaneamente, de vários narradores; mistura realidade, sonho, delírio, para criar um clima de incerteza; sugere um embaralhamento na ordem espacial e temporal dos acontecimentos, numa extrema fragmentação, privilegiando o texto, o ato de escrever.

A escritura pós-moderna em Portugal contempla uma gama variada de temas: a opressão ditatorial; o peso da tradição; a descaracterização de um povo; a condição feminina; Revolução dos Cravos. Estes estão relacionados ao contexto sócio-cultural português, no período anterior à Revolução dos Cravos (mais precisamente o período em que Oliveira Salazar governava o país) e também ao período posterior à revolução (período de muitas transformações em Portugal). Com efeito, nela é perceptível a marca registrada da ficção portuguesa contemporânea, com sua tendência inata para contemplar os problemas político-sociais do país. Desse modo, o romance português contemporâneo não só fará um inventário crítico da situação sociopolítico-econômica portuguesa, como também dos elementos que compõem a estrutura desse romance e do compromisso do escritor com a realidade.

Neste romance de Lídia Jorge é possível notar a presença destes temas pela forma como a autora constrói a narrativa, se valendo de elementos que apontam para o culto ao passado (tomando a personagem Jose Jorge Júnior como exemplo); para a submissão da mulher perante o homem (é o caso de personagens como Branca Volante e Esperança Tereza); para uma opressão (mostrada por todas as personagens, reflexo do regime de Salazar). A tendência à revisão da História de Portugal acompanha toda a narrativa: a já tradicional menção à epicidade do povo lusitano, tal como foi construída por Camões n'Os Lusíadas, também comparece em $O$ Dia dos Prodígios, porém de forma rebaixada, na figura das personagens humildes e solitárias de Vilamaninhos. Outro aspecto que se pode ver na obra é a alusão à Guerra, com um tom que é ora de crítica, ora de esperança num futuro sem contornos definidos ou de nostalgia de um passado absolutamente perfeito (no sentido de completamente acabado e irreversível). Por exemplo, quando José Jorge Júnior está relembrando os seus antepassados; há também, praticamente durante toda a narrativa, traços que apontam para o regime salazarista (pela opressão que se 
insere na comunidade de Vilamaninhos); e, ainda, há a presença da Revolução dos Cravos, fato histórico que dá sustentação à narrativa.

No âmbito da linguagem, um recurso significativo de que a autora se vale é a paródia, que se mostra por meio das ações de algumas personagens e pelo efeito parodístico que se forma em torno destas ações.

A paródia aponta para duas posições principais: tanto para a riqueza simbólica de que se reveste um discurso, por um lado, quanto para conduzir a decodificações que levam ao que se pode chamar de "avesso do texto", por outro. Há, portanto, "uma nova e diferente maneira de ler o convencional; um processo de liberação do discurso e uma tomada de consciência crítica" (SANT'ANNA, 2000: 31). Considera-se a paródia, então, um ato crítico de reavaliação e acomodação, pois recusa e esvazia um modelo original para recriar e preencher um modelo preexistente.

Como postulou Sant'anna (Ibidem), a paródia apresenta-se como canto paralelo, como diálogo intertextual ou como simples retomada de um texto preexistente que se afirma ao se negar. Considerada como a linguagem da inversão, a paródia inscreve o "mesmo", mas obliquamente, ao revés, revirado, e o reconduz ao novo texto como crítica. Como linguagem de ruptura, este recurso procura um corte com o convencional realizando uma inversão e um deslocamento. Em outras palavras, a paródia apresenta-se como uma escrita autocrítica, a voz social ou individual reprimida, que é preciso desentranhar para que se conheça o outro lado da "verdade".

Isso posto, pode-se afirmar que Bakhtin, a partir do formalismo russo, é o primeiro teórico a apresentar o conceito de dialogismo a partir da redefinição de outros conceitos anteriores a este, a paródia e a estilização. O conceito de paródia torna-se mais sofisticado a partir de Tynianov, quando é feito um estudo lado a lado com o conceito de estilização. Verifica-se, porém, que há uma coincidência com relação aos pensamentos destes teóricos. Tynianov, citado por Sant'anna (Ibidem: 13) defendeu que

a estilização está próxima da paródia. Uma e outra vivem de uma vida dupla; além da obra há um segundo plano estilizado ou parodiado. Mas na paródia, os dois planos devem ser necessariamente discordantes, deslocados. 
Já na estilização não há discordância e sim concordância nos dois planos. Portanto, da estilização à paródia não há mais que um passo, pois quando a estilização se mostra como uma motivação cômica acaba se convertendo em paródia.

Sob a ótica de Bakhtin, apesar das diferenças substanciais, a paródia pode ser colocada ao lado da estilização, pois, de acordo com Fávero (1999: 53) ambas apresentam traços em comum, que "permitem reconhecer explicitamente uma semelhança com aquilo que negam". Desse modo, a palavra apresenta-se com um duplo sentido, voltando-se para o discurso de um outro e para o objeto do discurso como palavra. Por outras palavras, é possível notar que, em um único discurso, podem-se encontrar duas orientações interpretativas, ou seja, duas vozes. Sendo assim, na paródia a linguagem torna-se dupla, pois se mostra como uma escrita transgressora, que engole e transforma o texto primeiro, reestruturando-se sobre ele, mas, ao mesmo tempo, negando-o.

O princípio dialógico permeia a concepção de Bakhtin de linguagem, e, quem sabe, de mundo e de vida. Dialogismo é o princípio constitutivo da linguagem, e esta, em qualquer campo e em qualquer circunstância, está impregnada de relações dialógicas. A concepção dialógica contém a idéia de relatividade da autoria individual e, conseqüentemente, o destaque do seu caráter coletivo. Nesta concepção, o homem não se constitui isoladamente e a experiência de vida deste indivíduo se tece na relação com o outro.

Pensar em relação dialógica é remeter a um outro princípio - a não autonomia do discurso. Para tanto, na linguagem bakhtiniana, a noção do eu nunca é individual, mas social. Os processos de formação do eu, para Bakhtin, se desenvolvem por meio de três categorias: o eupara-mim, o eu-para-os-outros, o outro-para-mim. Sendo assim, a concepção de diálogo somente se concretiza na relação subjetiva "eu-tu". Para o autor, o dialogismo interacional só pode ser entendido pelo deslocamento do conceito de sujeito. O sujeito perde o papel de centro para ser substituído por diferentes, ainda que duas, vozes sociais. Deste modo,

concebe-se o dialogismo como espaço interacional entre o eu e o tu ou entre o eu e o outro, no texto. Explicam-se as freqüentes referências que faz Bakhtin ao papel do 'outro' na constituição do sentido ou sua insistência em afirmar que nenhuma palavra é nossa, mas traz em si a perspectiva de outra voz (BARROS, 1999: 3). 
No dialogismo há, ainda, outro aspecto a ser observado: aquele que se refere ao diálogo entre os muitos textos da cultura, a intertextualidade. Deve-se notar que a intertextualidade, segundo Bakhtin, se processa, primeiramente, no interior do texto, mostrando-se como uma intertextualidade interna, que se apropria de vozes que falam e polemizam no texto. Deste modo é a partir deste vozear que se produz o diálogo com outros textos.

Em O Dia dos Prodígios, a autora constrói o texto de modo a estabelecer um diálogo também com outros textos. Dessa maneira, nota-se o efeito paródico quando faz referência aos ilustres heróis portugueses - Viriato, Egas Moniz, Vasco da Gama, Luso, dentre outros - que, nos feitos portugueses, revelam-se

Bravos em vista e feros nos aspeitos, / Mais bravos e mais feros se conhecem, / Pela fama, nas obras e nos feitos; / Antigos são, mas inda resplandecem / Co’o nome entre os engenhos mais perfeitos (CAMÕES, s/d: 283).

Todas essas figuras que comparecem na obra de Camões estão representadas na obra de Lídia Jorge por Manuel Gertrudes, Macário, Pássaro Volante, José Jorge Júnior, mas estes não são garbosos e dotados de coragem como os primeiros; são frágeis. Por meio desta intertextualidade é possível notar a construção de um mundo ao contrário, não somente pela caracterização dos heróis, mas também pelo comportamento dos habitantes do vilarejo. E este mundo ao contrário remete à paródia.

Um momento que pode ilustrar esse efeito é quando a personagem Carminha Rosa, ao ir até o banheiro para fazer suas necessidades, encontra uma foto minúscula estampada em um pequeno recorte de jornal. Neste "rectangulozinho junto a margem onde começavam os discursos" (JORGE, 1982: 98) estava anunciada a morte do noivo de Carminha Parda, sua filha. Carminha, a Rosa, não acredita no que lê, então "pôs-se a ler alto para ter a certeza de que era mentira o que acabava de compreender. Mas quanto mais e mais alto lia, mais lia a mesma coisa" (Ibidem: 98). Nota-se que há, neste fragmento, um confronto entre dois mundos: o da cultura e o da natureza (entendendo-se por mundo da natureza aquele em que os indivíduos não ascenderam a um grau mais elevado de consciência, não tiveram acesso à educação).

Esse episódio permite constatar, por meio do recurso ao grotesco carnavalizador, a precariedade das condições intelectuais daqueles moradores e o pouco acesso deles à educação e aos meios de instrução. A voz narrativa capta, solidariamente, a dificuldade da personagem para 
capar o sentido daquelas palavras, dificuldade a que se somam o desespero e a ansiedade, conforme fica implícito no enunciado a seguir:

E Carminha Rosa, com o dedo indicador apontado, e os olhos convergindo nas letras, pôde exercitar a vista. Leu palavras e palavras. Depois palavras com palavras. E depois pensou nos pensamentos das palavras dos quadradinhos (JORGE, 1982: 98).

Este episódio em que a mãe toma conhecimento da morte do noivo da filha é muito significativo. Ele ganha dramaticidade pelo modo como ocorre a situação e como a cena é narrada: a personagem Carminha Rosa está em um momento que poderia ser considerado de total privacidade, mas não o é, pois a latrina está construída a céu aberto, tendo ao alcance das mãos um pedaço de papel jornal que, além do rádio, ou 'telefonia' de Pássaro Volante (uma das personagens mais idosas da narrativa) era o único meio de comunicação que se tinha entre a vila e o mundo.

A esse respeito, nota-se que há um rebaixamento da privacidade, pois aquele era um momento muito particular e impróprio para a descoberta da morte de alguém de seu convívio e, particularmente, de um soldado que ela considerava como um herói da pátria. Mas não somente a perda da privacidade é evidenciada neste episódio. Além disso, existe a presença do escatológico, pois, pelo que parece, nada mais importa, já que qualquer ação que se desenvolva na Vilamaninhos está caminhando para o fim do homem e do mundo. Desse modo, as ações se desenrolam sem que se discrimine o público do privado e pouca importância se dá as coisas e as pessoas.

Observa-se a demonstração da importância que se dava a um "herói da pátria", pois aquele morreu num ato de bravura, defendendo sua pátria, e sua morte foi descoberta por acaso. A notícia veio em meio à propaganda de produtos, como se o herói fosse mais um produto descartável. Isto ressalta a condição rebaixada e marginalizada a que a autora nivela o reconhecimento que os veículos institucionais conferem aos defensores da pátria. Este é um modo de representação do herói de maneira paródica, pois, como mostra a obra de Lídia, ele não recebe o devido glamour que um herói merece, não sendo exaltado e enaltecido a ponto de ter sua morte anunciada em um jornal em meio a outras notícias sem a menor importância. Desse modo, o herói, na obra em questão, apresenta-se de maneira contrária à convencional, pois se insere em 
um "mundo às avessas", como descreveu Bakhtin (2002) em seu estudo sobre Rabelais. Enfim, a defesa da pátria acaba sendo reduzida a uma "caganificância".

Há também, na obra em estudo, um episódio que contém um efeito paródico, aquele que se refere aos cães copulando em praça pública. Apresenta-se, então, a descrição desse ato sexual entre os animais no seguinte trecho:

O cão amarelo-trigo tinha possuído a cadela no meio do largo, e sendo a cadela um palmo de mão mais baixa do que o seu macho, ficava ela com as patas traseiras penduradas, Virando a cabeça para um e outro lado. Os olhos líquidos pranteados. E os outros, amansados, observavam deitados e em pé, de orelha em riste, complacentes e espectadores (JORGE, 1982: 120).

Interessante observar que os vilamaninhenses param para ver o espetáculo que acontece na praça. Para eles aquilo era algo extraordinário e, por isso, tamanha importância era dada ao episódio. Isto ocorre pelo fato de não acontecer nada de diferente no vilarejo e evidencia quão rudimentar é o nível de consciência daquela gente. Sendo assim, usando a fundamentação de Bakhtin (2002), o espaço de Vilamaninhos é o do segundo mundo, da segunda vida, que existe paralelamente ao mundo oficial, o da realidade lisboeta.

Esta maneira de ver o mundo está vinculada ao que o pensador russo chamou de "paródia carnavalesca". Ela se caracteriza pela lógica original das coisas "ao avesso" e pelas permutações constantes do alto e do baixo, dando uma idéia de degradação do alto "sublime" para se aproximar do baixo "grotesco". Um traço marcante do "realismo grotesco" é o "rebaixamento", isto é, a transferência ao plano material e corporal, de tudo aquilo que é elevado. De acordo com Bakhtin (Ibidem: 18), a degradação do sublime parece não apresentar um caráter formal, pois "o 'alto' e o ‘baixo' possuem um sentido absoluto e rigorosamente topográfico. O 'alto' é o céu, o 'baixo' é a terra".

Na obra em estudo, nota-se o 'baixo' quando se toma como exemplo o episódio dos cães. Trata-se de uma cena que começa em uma taberna, no momento em que o Sargento Marinho, o segundo noivo de Carminha Parda, narra suas aventuras em África. Era tarde de domingo e todos estavam ali em volta da praça: uns assistindo à missa que acontecia; outros na taberna ouvindo as histórias do Sargento; enquanto outros passeavam pela praça. Em meio a estes acontecimentos surgem na praça alguns cães, cheirando-se e revolvendo-se as caudas umas atrás das outras. 
Diante desta situação, surge um constrangimento e isto causa certo incomodo naqueles que presenciam o fato. Por isso, o Sargento, o segundo noivo de Carminha Parda, "brandiu o cajado entre os dois corpos" (Ibidem: 122) e decepou o órgão genital do cão.

Por meio do comportamento desumano do Sargento Marinho em relação aos cães é possível observar que há algo diferente no que se refere aos papéis sociais, pois o homem (aquele que se pretende racional e dotado de consciência) age claramente como um animal, pela ação que se desencadeia no episódio dos cães. O Sargento, aquele que se posiciona como dominador, heróico, pelos atos de bravura que coloca em evidência quando relata suas aventuras em África, rebaixa-se ao nível dos animais quando castra o cão. Ao rebaixar-se, o sargento também rebaixa os heróis portugueses, pois, pelo que se nota, ele representa aqueles que lutaram bravamente pela pátria. Este rebaixamento do Sargento sugere um nivelamento, pois o oficial, por meio de suas atitudes, deixa vir à tona, o seu instinto animal e este se sobrepõe à racionalidade que caracterizaria os humanos.

Vale a pena ressaltar que o rebaixamento não carrega em si somente o aspecto negativo, pois a degradação cava o túmulo corporal para dar lugar a um novo nascimento. Desse modo, a atitude do Sargento, na realidade, serviu para tirar Carminha Parda da condição de sonhadora, pois, ao presenciar aquela cena de castração literal, ela adverte: "quando chegar em casa, vou poder dizer. À minha mãe desconsertada. Solte as galinhas, embrulhe os lençóis, ponha uma guita, faça um laço, guarde as louças. Que eu vou dizer que não” (Ibidem: 124). A partir do momento em que Carminha decide não se casar, ela renasce, e abre-se, diante dela, uma janela para o mundo, para a vida. Por esse motivo, atribuí-se ao rebaixamento, não somente um valor destrutivo, mas, também, um valor regenerador. Segundo Bakhtin, o realismo grotesco não conhece outro baixo (o baixo é a terra que dá vida, é sempre o começo).

O mesmo episódio dos cães permite ao leitor observar a relação entre o raciocínio político (quando o Sargento enaltece o heroísmo português) e o mítico (no que se refere a Carminha). Logo depois da castração, quando Carminha opta por não casar, parece que ela está sendo chamada para a realidade. Ela deixa de olhar para um passado remoto, para um tempo mítico, resolve assumir o presente e se coloca à disposição para o que está por vir. Neste momento, Carminha não está mais preocupada se vai ou não encontrar um noivo; o importante é que ela abandonou aquela condição de mulher isolada e passou a esperar por algo, independentemente do que pudesse acontecer. Neste caso, parece que, involuntariamente, o Sargento, com seu ato 
grotesco, propiciou, para Carminha, o despertar de uma visão de mundo que se amplia e se estende para além do microcosmo de Vilamaninhos.

As imagens grotescas conservam uma natureza original e estas são diferentes das imagens da vida cotidiana, preestabelecidas e, aparentemente, perfeitas. São imagens que parecem disformes, monstruosas e horrendas, mas se inserem na vida real e se opõem às imagens clássicas do corpo humano acabado e perfeito. Como se criassem, em praça pública, com este episódio, um tipo particular de comunicação, inconcebível em situações normais. Desse modo, formas especiais de vocabulário são elaboradas: francas, sem restrições e liberadas das normas correntes de etiqueta e de decência.

Exemplifica-se este fato por meio de um relato feito pela personagem Manuel Gertrudes, que conta ao Sargento um caso de uma moça que foi estuprada pelo avô: "O filho da puta do velho. Tão velho que parecia um insecto [...] Serviu-se da moça sua neta que apenas tinha treze anos..." (JORGE, 1982: 120). Observa-se, neste discurso, a falta de polidez e o uso de expressões inconvenientes. Este tipo de linguagem aproxima as pessoas do vilarejo dando um tom de linguagem familiar, pois se caracteriza pelo uso freqüente de grosserias, ou seja, de expressões e palavras injuriosas. Este modo discursivo evidencia-se não somente neste episódio, mas ao longo de todo o romance, principalmente quando a personagem Jesuína Palha se manifesta.

Há também, na narrativa, momentos em que se faz referência a insetos convivendo com as personagens, formigas, por exemplo. Este inseto era uma praga que havia se instalado na casa das personagens José Jorge Junior e Esperancinha Tereza (casal de idosos que habitam a vila) e "quando marido e mulher se sentaram à mesa. Já as encontraram no pão e nos copos, banqueteando-se muito antes dos donos da casa" (Ibidem: 132). Trata-se de pequenos insetos que tomam toda a atenção de José Jorge, pois estendia "toda a palma da mão, a direita, muito mais hábil em tais circunstâncias, e curvado para os ladrilhos da casa, procurava durante horas carrilhos de formigas" (Ibidem: 132). O comportamento de José Jorge pode ser um exemplo de ensimesmamento, pois, enquanto se preocupa com as formigas, soldados e grandes chefes fazem uma revolução. Isto mostra que não somente José Jorge, mas toda a comunidade de Vilamaninhos parece não ter consciência do que estava acontecendo ao redor. Eles se igualam a insetos (quando José Junior, ao curvar-se para procurar as formigas, rebaixa-se para ficar no mesmo nível que elas) e a animais (no que se refere aos cães). Esta condição inferiorizada e 
rebaixada na qual se colocam não permite que grande parte dos vilamaninhenses evoluam intelectualmente.

Pelo que se pode notar, o recurso à paródia carnavalesca está presente em quase toda a narrativa, assinalando a distância irremediável entre os dois universos: o da civilização e o da sociedade periférica da aldeia.

Há, também, na obra de Lídia Jorge, um fato histórico, a Revolução dos Cravos, que, além de permear a narrativa, serve como ilustração para o processo de alienação. Esta Revolução é um dos temas que contempla a escritura pós-moderna e que se apresenta como foco principal no romance de Lídia Jorge.

A Revolução dos Cravos, ocorrida em 25 de Abril de 1974, é, sem dúvida, um marco na história de Portugal, pois esse levantamento militar derrubou, num só dia, o regime político que vigorava em Portugal desde1926. O 25 de Abril foi conduzido pelos oficiais intermédios da hierarquia militar (o MFA, Movimento das Forças Armadas), na sua maior parte capitães que tinham participado da Guerra Colonial (período de confrontos entre as Forças Armadas Portuguesas e as forças organizadas pelos movimentos de libertação das antigas províncias ultramarinas de Angola, Guiné e Moçambique, entre 1961 e 1974). Considera-se, em termos gerais, que esta revolução devolveu a liberdade ao povo português.

O movimento revolucionário de 25 Abril de 74 foi ocasionado pelo apogeu de um descontentamento apresentado pelo povo português pela implementação de um regime autoritário de inspiração fascista. Esse regime é denominado por Estado Novo ou II República. Este é um regime político autoritário, conservador, tradicionalista, anti-democrático e repressivo (apoiado na PIDE, Polícia Internacional e de Defesa do Estado), instituído sob a direção de Antônio de Oliveira Salazar, um conservador e tradicionalista católico que governou Portugal durante 41 anos, desde 1933 (com a aprovação de uma nova Constituição por plebiscito nacional) a 1968 (quando foi acometido por uma queda em que sofreu lesões cerebrais). Após o seu afastamento, Salazar foi substituído por Marcello Caetano que governou até 1974.

A ditadura salazarista baseava seu aparato repressivo nas forças armadas, na qual destacase a PIDE. No salazarismo, semeava-se o terror, o medo e o silêncio na sociedade, pois os opositores eram torturados, interrogados e mantidos, se necessário, em prisões e campos de concentração. A Igreja Católica, como afirma Secco (2004: 56) "difundia a ideologia da ordem, da noção de dilatação da fé e do império como fatos coligados e indissociáveis". Por outras 
palavras, Salazar, que se pretende um homem religioso, católico, associa o seu regime militar à Igreja Católica. Isto garante à Igreja Católica, dentre outros privilégios, o livre exercício da sua autoridade sobre a sociedade portuguesa.

O povo português vivia, então, sob pressão, pois estavam sob os demandos da ditadura salazarista e também sob as ordens da Igreja Católica. Por conta disso, havia um desgaste e uma insatisfação muito grande na sociedade, mas também estavam descontentes com o advento da Guerrra Colonial (período de confrontos entre as Forças Armadas Portuguesas e as forças organizadas pelos movimentos de libertação das antigas províncias ultramarinas). Em consequência disto, os oficiais de média patente se rebelam e acontece a Revolução dos Cravos.

Sob o ponto de vista histórico, a Revolução causou em Portugal uma grande transformação nos diversos setores políticos, econômicos e sociais. No âmbito literário não foi diferente, pois, com o florescer da Revolução, a narrativa portuguesa passa a ser produzida pelos escritores com um novo olhar, aquele que não mais se baseia em um contexto social dominado pela opressão ditatorial, mas um olhar que tem uma perspectiva de progresso, de inovação.

No período imediatamente posterior ao 25 de Abril há indícios de que houve um decréscimo da produção romanesca em Portugal. De acordo com Lídia Jorge, citada por Gomes (1993: 146) “o que aconteceu foi que o país ficou em estado de sítio, no bom sentido”. Em outras palavras, as pessoas que estavam escrevendo naquele momento pararam de produzir,

porque houve um momento cívico com uma força tão grande, com uma turbulência tão grande, que os escritores sentiram que não queriam escrever como estavam a escrever até ai, pois não tinham feito a síntese necessária, para perseguir um novo caminho (Ibidem).

Com o advento do 25 de Abril surgiu, no povo português, a necessidade de reformulação de suas referências em relação ao mundo, bem como a necessidade de refazer a própria mitologia subjacente. A revolução deveria ser vista, por toda a sociedade portuguesa, como uma forma de esperança, de progresso, de inovação, como uma nova maneira de encarar o mundo, afinal livrou Portugal de uma ditadura muito intensa. Mas, para uma parcela da população, principalmente aqueles que habitavam nos campos, ela não teve grandes repercussões. Mesmo após a revolução, aqueles que estavam distante do grande centro, Lisboa, continuavam realizando serviços braçais e completamente sem recursos para levar uma vida confortável. 
No que concerne a Vilamaninhos, microcosmos de $O$ Dia dos Prodígios, observa-se que a revolução não teve um efeito muito positivo, pois se trata de uma vila do interior do Algarve que não evoluiu junto com as transformações que ocorreram em Portugal, ao contrário, permaneceu estagnada e sem intenção de progresso. Desse modo, a maneira pela qual o povo de Vilamaninhos percebeu a revolução mostra que estão alheios ao mundo em que vivem.

A notícia acerca da revolução chega à vila através do único meio de comunicação que se tem, o rádio de Pássaro Volante e, também, através de Maria Rebola, dona do bar, que também contribui dizendo: "em Lisboa os soldados fizeram uma revolução para melhorarem a vida de toda aquela gente? Uma re vo lu ção?”(JORGE, 1982: 133).

Jesuína Palha, a porta-voz da comunidade, também se encarrega de avisar aos habitantes sobre a revolução, mas não deixou de expor as suas críticas sobre o assunto:

Gente que já tem luzes [...] Gente que basta fazer assim com o dedo mindinho, para que todos os instrumentos comecem a fazer o serviço por eles mesmos como se tivessem braços. [...] Gente que come carne todos os dias da semana [...] Gente que já tem tudo o que nem é possível a gente imaginar [...] E essa gente ainda não estava conformada com o destino (Ibidem: 141-143).

A porta-voz da comunidade procura enfatizar o distanciamento que há entre os habitantes do vilarejo e aqueles que vivem em Lisboa, dizendo:

E essa gente se quisesse nem precisava calçar sapatos para andar. Lá todos os dias as ruas são limpas de madrugada [...] E as luzes. Dizem. Ficam acesas toda a noite, para aluminar as casas. [...] Aqui é uma tristeza. Vejam. Mesmo as ruas que as donas queriam ter limpas, cedo ou tarde parecem um mar de porqueira em campo de besaranha (Ibidem: 143).

Neste romance a autora revisita sob uma perspectiva irônica, esse "dia maravilhoso" do 25 de Abril de 1974. Neste caso, a ironia se processa pela reação que os vilamaninhenses tiveram ao se depararem com os soldados. No final do romance, os soldados anunciam aos habitantes da aldeia que havia acontecido uma revolução. Os camponeses, incapazes de compreender o quanto aquele fato contribuía para o progresso de toda a sociedade, acreditavam que os soldados estavam ali por qualquer razão menos para anunciar uma revolução. Desse modo, enquanto toda a nação 
portuguesa lutava pelos seus ideais, os vilamaninhenses "dormiam e faziam baracinha como se nada fosse" (Ibidem: 141).

O impacto causado pela revolução deveria transformar toda a sociedade portuguesa. Contudo, ao que parece, tais mudanças operam-se somente na superfície, pois as estruturas menos esclarecidas, representadas no romance pelos vilamaninhenses, continuam intactas. Para a comunidade de Vilamaninhos, a Revolução era um misto de fantasia e realidade, pois acreditavam que os soldados estavam visitando todos os vilarejos de Portugal para "ouvir todas as queixas" (Ibidem: 134) e, conseqüentemente, tirá-los da miséria. Ficavam eufóricos quando pensavam na visita dos soldados, mas logo percebiam "Que se tinham alvoroçado por nada" (Ibidem: 157) porque "Esses que aí vieram mostrar-se nem chegaram a ouvir a voz da gente" (Ibidem).

O fato é que os soldados não estavam ali para ouvir as histórias e lamentações daquele povo, mas sim para preenchê-los com um discurso cheio de idéias e significado. Embora falassem sobre liberdade de expressão e união entre todos os povos, "ninguém compreendeu as palavras" (Ibidem: 161). Essa forma de comunicação deficiente que se estabelece entre vilamaninhenses e soldados é mostrada quando um dos soldados direciona-se a toda a comunidade, dizendo acreditar que "aquela era a hora dos humilhados e dos oprimidos" (Ibidem, 154). Manuel Gertrudes mostrando sua falta de consciência política responde: "E quem são esses?" (Ibidem: 161).

Nota-se que as personagens, representando a sociedade portuguesa que habita fora dos grandes centros não vivencia a revolução, pois não dá conta da importância desse acontecimento e das transformações que o país sofre com ela. A maneira como perceberam a revolução, mostra o quanto os aldeões estavam fechados em si mesmos, impossibilitados de enxergar o que quer que estivesse fora do âmbito da visão de mundo limitada que tinham. Isso pode ser ilustrado pelo fato de os habitantes do vilarejo serem incapazes de avaliar as conseqüências do movimento revolucionário de 74, que se oferece a eles como notícia com a chegada de "soldados garbosos e épicos, penetrando já pelo centro de Vilamaninhos com bandeiras e flores” (JORGE, 1982: 152).

Para os habitantes do vilarejo, os soldados ali presentes são seres de outro planeta, enviados do céu. Tanto que Jesuína diz: "Vem ai um carro. Um carro celestial. Celestial. Olhem todos. Traz os anjos e os arcanjos [...] Vamos ser visitados por seres saídos do céu, e vindos de outras esferas. Onde os séculos têm outra idade" (Ibidem: 152). Na realidade os vilamaninhenses 
acreditam que os soldados estão ali para explicar o desaparecimento da cobra-dragão e para colocar fim em todas as aflições pelas quais haviam passado por conta do desaparecimento do réptil. Este modo de agir, como seres que vivem sem conhecer ou compreender os fatores políticos que os condicionam e os impulsos que os levam a agir desta maneira, comprova a alienação do povo da vila, pois, voluntariamente ou não, os vilamaninhenses mantinham-se distantes da realidade que os cercava. Depois deste episódio a vida dos camponeses se resume em esperar por algo ou alguém que venha para explicar o acontecido. "Vão tão lentos os dias nesta espera" (Ibidem: 150) que aquela expectativa presente no início do texto vai se transformando, ao longo da narrativa, em desilusão e frustração.

Quando Jesuína, a porta-voz da sociedade, relata para os soldados a história de uma cobra executada por ela e que, de repente, esta cobra alça vôo e desaparece no ar, eles dizem: "Estamos todos contentes, porque registramos que nesta terra ainda se gosta de milagres. Já começa a ser raro" (Ibidem, 157). Depois disso os soldados desaparecem do vilarejo. Após a partida dos soldados, a vida perde o sentido para os camponeses, pois, como disse a personagem Macário, um cantador lunático, "sempre que damos ouvidos a outros [...] levam a esperança que a gente tem" (Ibidem: 158). Diante do relato de Jesuína os soldados tiveram a confirmação de que o povo daquele vilarejo encontrava-se num estado de alienação profunda e, por conta disso, não tinham conhecimento dos benefícios que essa revolução poderia trazer para toda a sociedade portuguesa.

Desse modo, as personagens situavam-se ilhadas entre um passado esgotado e um futuro sem perspectivas, que nem mesmo o fenômeno da Revolução pôde salvar. O comportamento dos vilamaninhenses diante da notícia da revolução era uma amostra de que estavam completamente afastados de sua real natureza. Em outras palavras, não eram capazes de perceber a importância desse acontecimento porque estavam alienados e, para eles, o mundo se restringia àquele vilarejo e as pessoas que ali habitavam.

Ao que parece, a idéia de Revolução para os habitantes daquela vila era apenas "assombração" ou "ilusão de sentidos" (JORGE, 1982: 162). O fato de as pessoas do vilarejo serem mencionadas pelo soldado como "alavanca dos prodígios" (Ibidem, 154), na realidade, os torna ainda mais impotentes, pois continuam vivendo na mesmice de antes. O título da obra $O$ Dia dos Prodígios simplesmente reforça, ironicamente, essa visão equivocada que os vilamaninhenses tinham sobre a revolução, pois o prodígio que deveria ser algo extraordinário, maravilhoso, sinônimo de mudança, acaba se transformando em um pesadelo. Os camponeses 
logo percebem que essa transformação que esperavam acontecer, pelo ressurgimento da cobradragão ou pelo aparecimento dos soldados na vila, não se concretizaria, pois a transformação não era algo que viria de fora, algo que se continha num espaço comum, visível, mas sim, de acordo com Gomes (1993), algo que estava no interior de cada habitante do vilarejo e caberia a cada um deles transformar-se ou não.

A autora coloca o leitor diante de uma história, aparentemente, comum, mas que se origina por meio de uma cultura mítica. Nesta história há um momento de ruptura, que chama as personagens desta narrativa para a realidade, a Revolução dos Cravos.

Mas, frente à revolução, Lídia Jorge promove a mitologização da história, ou seja, cria, a partir de um fato histórico, sua própria mitologia e isto provoca o exagero da experiência cotidiana alicerçada na imaginação mítica. Por conta disso, o povo de Vilamaninhos, parcela significativa do povo português, não chegou a reconhecer o momento histórico que vivia.

É possível notar que $O$ Dia dos Prodígios pode ser traduzido como metáfora dos acontecimentos anteriores e posteriores à Revolução de Abril. A obra identifica-se no período anterior por caracterizar-se pela anestesia do povo de Vilamaninhos e pelo atraso econômico e cultural. Pode-se enquadrar, também, a narrativa de Lídia Jorge, no posterior à Revolução em razão da euforia e da ansiedade que se instala por conta deste acontecimento.

No que se refere a Portugal, observa-se que, após a Revolução, os portugueses tentam viver as décadas de história européia de que se viram privados pelo regime ditatorial. Em meio a esta euforia inicial aparecem as dificuldades do período crítico da construção da democracia. Além disso, a entrada de Portugal na Comunidade Européia (algo que deveria ser bom, pois isto ofereceria a Portugal a possibilidade de deixar de estar só e de permanecer num ostracismo) não atendeu as expectativas. Isso ocorre pelo fato desta modernização social chocar-se com crescentes dificuldades financeiras, o que faz continuar a desigualdade, o arcaísmo e a desorganização social. Com isso a busca da integridade na Comunidade Européia termina por desmascarar as fragilidades de uma nação que não se enquadra nem no primeiro e nem no terceiro mundo. Deste modo, como postulou Lourenço (1994: 181), Portugal permanece "parado num pós-25 de Abril que não acaba de acabar”.

No que concerne à obra de Lídia Jorge é possível notar que a euforia dura até o instante em que os soldados chegam ao vilarejo e deixam transparecer, por meio de seu discurso, que não estão ali para explicar a história da cobra, mas sim para falar de uma Revolução. Naquele 
momento, tudo parou na Vilamaninhos e nada mais se ouvia a respeito da cobra. Sendo assim, a presença deste tema, Revolução dos Cravos, na narrativa de Lídia Jorge, pela maneira como foi visto pelo povo do vilarejo, serve para mostrar o quanto estavam fechados em si mesmos, sem consciência da realidade que os circundava e sem capacidade de refletir. 


\section{CAPÍTULO II}

\section{AS MANIFESTAÇÕES DA CONSCIÊNCIA}

A tessitura narrativa de O Dia dos Prodígios delineia os contornos do próprio enclausuramento da aldeia, desde o seu formato de estrela até a linguagem arcaica e o discurso atomizado dos seus habitantes, entre outros elementos que igualmente contribuem para fazer da obra uma alegoria de um país fechado e estagnado, maneira pela qual Portugal se apresentou quando esteve sob os efeitos do regime militar que vigorou no período anterior à revolução de Abril de 74.

De fato, os vilamaninhenses estão permanentemente à espera de uma força exterior que os transforme. Assim são apresentados como uma sociedade isolada e intolerante no seu próprio seio. Pelo que se pode notar pelo comportamento das personagens, há um distanciamento, não somente em relação àquilo que é externo ao vilarejo, mas, principalmente, em relação àquilo que se refere a eles mesmos. A personagem Jesuína Palha, por exemplo, protagonista no episódio da cobra, se incompatibiliza com as duas Carmens, não porque haja alguma rixa entre elas, mas porque as expectativas em relação ao porvir são diferentes (o que revela uma diferença no nível de consciência dos dois grupos que elas formam); há os casais - Pássaro e Branca Volante; José Jorge Júnior e Esperancinha - cujos diálogos são, na verdade, monólogos, porque não se ouvem 
um ao outro, estão confinados em seu ensimesmamento. Enfim, essa condição de marginalidade os impede de desenvolver a consciência e de, conseqüentemente, enquadrar-se num contexto social mais amplo.

Conforme já se disse no capítulo anterior, a linguagem humana ganha seu ser, sua essência, no seio do coletivo, na interação com o grupo; em outras palavras, o eu se constitui na relação com o outro, e o discurso sempre se constitui por possuir, em seu bojo, no mínimo, duas vozes. O grande drama das personagens que moram em Vilamaninhos está, então, nessa solidão e nesse isolamento que lhes trava o acesso ao real histórico e os condena a viver nesse universo mítico das sociedades arcaicas. A falta de contato com o mundo (ao que parece, o contato com o mundo exterior se limita, no máximo, a Faro, também no Algarve, bem no sul de Portugal, e, portanto, distante de Lisboa e de outros grandes centros onde estava ocorrendo o movimento revolucionário), numa época de progresso e de desenvolvimento tecnológico, é inconcebível; chega a ser um crime que a obra pretende revelar, o abandono de populações à margem da História - será Vilamaninhos o único exemplo? Vê-se essa condição no fragmento abaixo:

Era o novo século que estava a começar. Diziam. Muito atrasado nas nossas bandas. Uma era de coisas rápidas, toda feita de rodas e alavancas,roncos de pressa e velocidade. Mas muita gente enjoou. E muita gente quando voltava de Faro vinha amarela e tonta como se tivesse ido fazer compras e trazer mezinhas, e acabasse por dar uma volta ao mundo inteiro (JORGE, 1982: 52).

A afirmação, no capítulo anterior, de que Lídia Jorge promove, em O Dia dos Prodígios, à mitologização da História já aponta para os pólos, até agora desunidos, que compõem o retrato da patologia de Portugal, patologia que só poderá ser sanada se houver um compromisso sóciocultural voltado para a junção dos dois pólos ou para a minimização da distância entre eles.

Que pólos são esses? Um deles, onde estão concentrados, ficcionalmente, os habitantes de Vilamaninhos, evoca as regiões rurais de Portugal, protagonistas (em alguns momentos, especialmente as mulheres) de grandes problemas sócio-econômicos desde o século XIX; é o pólo regido pelo mito, pelas explicações sobrenaturais (ou pelas impossibilidades de explicação), o pólo onde o futuro, para quem ainda crê nele, está previsto de antemão e dele é impossível fugir. A atmosfera é, então, de aridez, tristeza e marasmo, e, às vezes, até de medo: 
O futuro é o presente a andar lentamente para trás. Na verdade abafava-se dentro de casa ou à janela, e mesmo sobre a calçada se ouvia o sussurro dos gafanhotos pedalando de pasto em pasto. Os telhados ondulavam sobre as paredes como se fossem cair e as paredes das casas abriam bocas como se fossem romper-se (JORGE, 1982: 159).

Neste pólo estão localizadas todas aquelas camadas não ilustradas da população, que tiveram pouco ou nenhum acesso à educação e ao convívio social. Essa carência determina uma limitação da capacidade de apreensão do real, apreensão que se reduz à imagem e não alcança o patamar do conceitual, tal como ocorre com as crianças em sua fase inicial de compreensão do mundo. Por exemplo, num momento muito poético em que os amigos e vizinhos estão reunidos para conversar (e esperar...):

Eh meninos, Algum de vocês já viu um barco? Eu não vi. Disse Francisco Volante. Mas é como uma cama com velas. E alguém já viu uma vela? Voltou a perguntar o cantoneiro. Eu. Disse Manuel Volante. Mas ela é um lenço de assoar dobrado por duas pontas. Muito. Muito bem. Disse o cantoneiro levantando o malho. E o mar. O mar já alguém viu? O mar, o mar. Disse Eusébio Volante. O mar é como um trigal cor do céu, azul (Ibidem: 94).

No outro pólo, o mundo civilizado, onde o homem é sujeito da sua própria história e colabora para construir a história da sua comunidade. Neste, o tempo é dinâmico, o discurso é apaixonado e, no caso de Portugal, impregnado do idealismo utópico advindo da fé no processo pós-revolucionário:

....aquela era a hora dos humilhados e dos oprimidos. E quem são esses? Perguntou Manuel Gertrudes. Quem são esses? E o soldado encheu o peito. Vocês. Vocês. São vocês. Repetia. Sem o saberem. Mas o futuro agora chama-se pre sen te. Basta apostarmos todos nos valores exactos. Vocês. Nossos parceiros. Alavanca dos prodígios. Dizia o soldado que por falar e mexer as mãos parecia mais garboso (Ibidem: 154).

Este excerto é igualmente exemplar para traduzir a dialética que promoveria a evolução do indivíduo e do seu grupo e possibilitaria a dinamização temporal (em oposição à estagnação 
dominante na aldeia): o eu e o tu (o "nós"), a soma de consciências, de ideais ("basta postarmos todos nos valores exactos").

Esse convite - na verdade o soldado pode ser visto como um porta-voz da ideologia revolucionária, na qual se engajaram os escritores da geração posterior à Revolução dos Cravos, inclusive a autora - seria o móvel da transformação dos vilamaninhenses em indivíduos capazes de atuar no seu meio, de se constituírem como sujeitos de seu próprio destino e do seu povo.

$\mathrm{Na}$ concepção hegeliana utilizada aqui como base teórica para o desenvolvimento da argumentação, a esse primeiro momento de interação entre um "eu" e um "tu" dá-se o nome de alienação. Assim, em Hegel esse conceito possui uma conotação positiva, na medida em que representa o primeiro passo para o desenvolvimento da consciência do indivíduo. Na verdade, o homem é o lugar por excelência da consciência; por isso o que Hegel focaliza não é o surgimento, mas o desenvolvimento da consciência, o qual se processa no seio do contexto histórico.

Para assimilar melhor a dinâmica implícita na Fenomenologia do Espírito, é relevante compreender, primeiro, como o autor concebe a Realidade. Trata-se do processo do vir a ser: a realidade não nos é dada, mas é continuamente alcançada pela alienação, pela mediação e pelo trabalho.

Outro conceito importante, mais do que o anterior até, na medida em que a Realidade é resultado do que este faz, é o conceito de Homem. Nas palavras do próprio Hegel:

El hombre aparece después de la creación de la naturaleza y constituye lo opuesto al mundo natural. Es el ser que se eleva al segundo mundo. Tenemos en nuestra conciencia universal dos reinos, el de la naturaleza y el del espíritu. El reino del espíritu es el creado por el hombre. Podemos forjarmos toda clase de representaciones sobre lo que sea el reino de dios; siempre há deser un reino del espíritu, que debe ser realizado en el hombre y establecido en la existência (HEGEL, 1982: 59).

E ainda:

El hombre, como espíritu, no es algo inmediato, sino esencialmente un ser que há vuelto sobre sí mismo. Este movimiento de mediación es un rasgo esencial del espíritu. Su actividad consiste em superar la inmediatez, en negar esta y, por 
consiguiente, en volver sobre sí mismo. Es, por tanto, el hombre aquello que él se hace, mediante su actividad. Solo lo que vuelve sobre sí mismo es sujeto, efectividad real (Ibidem: 64).

Em síntese, segundo o pensador romântico, desenvolver-se corresponde ao processo pelo qual o indivíduo (que ele concebe como espírito) se projeta para fora de si para, em seguida, por etapas sucessivas, retomar, no absoluto, a identidade consigo mesmo. Esta identidade consigo mesmo, ou seja, esta consciência de si, só se estabelece na relação com o outro. Por outras palavras, há um "eu", espírito, que entra em contato com um "outro"; este "outro" em contato com aquele "eu" expõe o seu ponto de vista, para que se possa criar um confronto de consciências; neste confronto de consciências uma nova consciência se forma, agora transformada, fazendo um retorno sobre si mesma e voltando para o "eu".

É por meio desta tríade dialética, que se constitui como um movimento cíclico, que Hegel, na Fenomenologia do Espírito, oferece a escada necessária para que o indivíduo chegue à compreensão de si mesmo enquanto espírito, atingindo o saber absoluto, pois só esta consciência plena, pode garantir ao homem seu desejo último, o de ser livre.

A liberdade, por sua vez, é atingida por um processo que exige o desensimesmamento do sujeito, para encontrar, reconhecer o outro, para além de si, mas que possibilita o próprio si e sua assunção. Pelo objeto, pelo outro, é que ocorre a tomada de consciência do eu. Trata-se de uma perda para que aconteça o ganho, um desencontro que resulta no encontro. Hegel condiciona a liberdade à centralidade do em si, ou seja, do sujeito, porém faz-se necessário o processo da passagem pelo para-si, no objeto, de modo que o centro seja alcançado. Contudo, o momento da centralidade, embora seja o da perfeição, não se caracteriza pela inabilidade, mas, ao contrário, pela contínua atividade. Essa é a marca do espírito que existe por si porque passa pelo outro de si mesmo

Desse modo, pelo que se pode notar, a consciência é a grande protagonista da aventura e da façanha de arrancar-se do mundo natural e se dar uma história. De acordo com as palavras de Labarrière citado por Hegel (1993: 22),

ela sai de si, retorna a si, se precipita, é travada, some, emerge, luta, se exprime, progride, afirma, nega, sofre, morre, crê, sabe, ignora, se divide, se reconhece, nos arrasta numa sarabanda desenfreada, freqüentemente inquieta e de repente 
apaziguada, se erguendo contra a evidência e cedendo à força das coisas, conhecendo a boa e a má fé, a prisão e o despertar da liberdade, se elevando enfim à sua verdadeira estatura, à atitude forte e modesta deste "saber absoluto" que conhece conceitualmente o mundo sem nada acrescentar-lhe e estabelece uma exigente identidade entre o que é dado e o que é compreendido.

Para Hyppolite (1991: 172), mais do que a simples consciência, é a consciência infeliz o tema fundamental da Fenomenologia do Espírito de Hegel. A dialética do Senhor e do Escravo vai conduzir à consciência infeliz que, ao projetar fora de si parte de seu eu, surge como consciência alienada. Vale a pena, antes de ater-se a consciência alienada, fazer uma breve explanação acerca da dialética do senhor e do escravo, pois esta descreve o processo pelo qual a luta das consciências, por meio do reconhecimento mútuo, conduz à dominação de uma por outra.

Trata-se de um episódio dialético, que consta na Fenomenologia do Espírito, em que as figuras especulativas do Senhor e do Escravo representam um drama, pois, ao estabelecerem um duelo, a consciência primitiva dela se diferencia para se reconhecer como singularidade frente a outra singularidade. Verifica-se, neste drama, que o lugar do Senhor está sendo superado, e caberá ao Escravo atualizar a cena, introduzindo a si mesmo e ao antigo Senhor como cidadãos.

O Senhor se constitui como tal ao se defrontar, enquanto consciência-de-si, com outra consciência-de-si que não ele mesmo, o Escravo. A subsistência "natural” de um outro que, não sendo coisa, se interpõe com desejo próprio ao seu desejo, é uma ameaça para o Senhor. Por esse motivo, se põe a exigência de uma luta de morte, e esta é enfrentada diferentemente por cada um: aquele que será o Senhor a aceita como necessária e a quer levar até o fim, nem tanto por coragem, mas por uma "indiferença" que tem à sua vida e pelo fato de aspirar e desejar o reconhecimento do outro. O Escravo teme diante da possibilidade de morte e seu profundo temor a este "Senhor absoluto" (a morte), o faz render-se como vencido. Quem manteve a "indiferença", a coragem e a vontade de lutar mesmo com o risco de morte, até o fim, é o vencedor, o Senhor. Quem, derrotado, prefere submeter-se ao outro a morrer, é o Escravo. O Senhor é a consciência autônoma, tornada para-si pela vitória e pela liberdade. Ao passo que o Escravo é a consciência que se submeteu para não arriscar a sua vida, prefere conformar-se com sua natureza animal, preservando a sua condição de servo, e reforçar, com sua submissão, sua participação no mundo natural das coisas. É agora um animal, assim se considera e assim é visto pelo Senhor. 
Hegel (2000: 128) postula, quando se refere a esse episódio, que esta luta não poderia ser evitada, pois, ao combaterem, ambos se elevam ao nível da verdade, atingindo a sua certeza de si, sua certeza de existir para si, e cada um deve experimentar essa certeza em si mesmo e no outro (por outras palavras, na luta entre estas duas consciências, Senhor x Escravo, Hegel examina simultaneamente a relação de dois "eu" e a relação de cada "eu" com sua própria vida). Desse modo, a liberdade do indivíduo só é conquistada quando ele arrisca a própria vida. Só assim é que alguém se assegura de que a natureza da consciência de si não é o ser puro, não é a forma imediata de sua manifestação. O indivíduo que não arriscou sua vida pode certamente ser reconhecido como pessoa, mas não atingiu a verdade desse reconhecimento como consciência de si independente.

Diante de sua vitória, o Senhor exerce o seu poder sobre o Escravo, incumbindo-o de diversos afazeres em prol de seu conforto, enquanto goza os prazeres da vida. $\mathrm{O}$ mundo do Escravo é o mundo da existência natural que ele transforma com o seu trabalho para atender às demandas do Senhor, pois o Escravo depende da satisfação deste Senhor para continuar vivendo. Esta transformação ocasionada pelo trabalho do Escravo garante ao Senhor certa comodidade, já que o Escravo se dispõe a servi-lo no que ele precisar, e isso faz com que o Senhor desconheça os rigores do mundo material. Desse modo, o Escravo acaba realizando uma mediação entre o Senhor e o mundo, e, também, uma mediação do Senhor consigo mesmo. Isto promove uma relação que induz o Escravo a transformar os objetos materiais em objetos de consumo e de fruição para o Senhor. Desse modo, o Senhor não é Senhor "em-si" só se reconhece como tal pela consciência do Escravo. Neste sentido, como afirma Hegel (ibidem), o Senhor é a consciência que é por si mesma, mas essa consciência, aqui, está além de seu puro conceito: ela é consciência para-si que é mediada consigo mesma por outra consciência.

Entretanto, dentro de uma linguagem não-hegeliana, o Escravo sente a possibilidade especificamente humana de transcendência, deixando a situação de dominado para ocupar a posição de dominador. Quando se trata do Escravo, é possível verificar que algo foi conquistado. A superioridade do Escravo diante do senhor reside, em primeiro lugar, na experimentação do medo. Este temor absoluto que o levou à submissão pode ser considerado como um começo de sabedoria, pois, desta maneira, o escravo aprendeu que não é possível, na sua singularidade, afrontar a morte. Em segundo lugar, o escravo trabalha para o senhor, e, pelo trabalho, adquire a cultura que só pertence ao Senhor de forma mediatizada, mas pertence ao Escravo de forma 
imediata e definitiva. Vale a pena esclarecer que o trabalho que forma e liberta o Escravo não é o do artesão solitário aristotélico, mas trabalho que o eleva acima de sua "singularidade egoísta", um serviço para outrem, um trabalho que visa uma alteridade. Por meio deste trabalho, o Escravo constrói a efetiva independência e autonomia, que lhe apontam a possibilidade concreta de ser livre, de atingir a liberdade que reside no domínio de si mesmo.

No que se refere aos habitantes de Vilamaninhos, é possível verificar, tomando como base a dialética do Senhor e do Escravo de Hegel, que os aldeões estão numa condição de inferioridade em relação aos soldados que adentraram o vilarejo para anunciarem a Revolução dos Cravos. Ao exporem seu discurso imponente e orgulhoso, relatando os benefícios que a vitória da Revolução proporcionou a nação Portuguesa, os soldados mostram-se superiores àqueles que habitam à vila, no que tange ao nível de consciência, pois é provável que os soldados, tendo em vista a dialética do reconhecimento de Hegel, estejam a caminho de reconhecerem a si mesmos enquanto espírito.

Ao passo que os camponeses ainda não atingiram a consciência-de-si, pois esse movimento da consciência-de-si em relação a uma outra consciência-de-si, para grande parte das personagens, não se concretiza. Mas, com relação a uma minoria, Branca Volante e Carminha Parda (personagens femininas oprimidas e alienadas), parece que esta consciência-de-si, de alguma forma, está sendo despertada. Por meio dessas duas personagens, nota-se que há esperança de que algo novo possa surgir e isto, talvez, signifique uma melhora. Isso ocorre pelo fato de terem saído daquele estado de consciência inicial, estagnado e parado no tempo, para atingir um outro estágio que remete a uma perspectiva de progresso.

A primeira consciência-de-si (a dos camponeses) parece não ter diante de si o objeto (a realidade de Portugal), pois, apesar de terem tomado ciência da Revolução, não sabiam exatamente o que era e o porquê de sua ocorrência. A consciência-de-si dos camponeses possui um objeto independente e peculiar ao povo de Vilamaninhos, objeto este que se remete aos problemas corriqueiros e as miudezas do cotidiano daquela vila.

Ao transpor a realidade de Vilamaninhos para a realidade portuguesa observa-se que as massas rurais, na maioria das vezes, encontram-se à margem do restante da sociedade e, quase sempre, numa condição de submissão em relação aos que vivem fora dos campos. Por esse motivo, a incultura e o analfabetismo eram quase gerais. Esta é uma situação que se instala em Portugal desde a época Medieval, ou até mesmo antes, e que perdura até a atualidade, pois o 
campesinato continua em desvantagem, no que se refere ao desenvolvimento social e econômico. Ao que parece, Lídia Jorge, em O Dia dos Prodígios, pretende retratar este Portugal rural que se arrastou durante décadas num imobilismo e isolamento, e isto se desenvolveu principalmente nas áreas agrícolas, num extenso e populoso "mundo rural", a ponto de se considerar, ele mesmo, um país rural.

Desse modo, os centros urbanos eram áreas minúsculas num espaço tomado e gerido pela população agrícola. Este espaço era movido pelos trabalhadores rurais, caseiros e pequenos agricultores, que viviam num estado de miséria, evidenciando uma grande desigualdade social. Por conta desta má distribuição de rendas e da pobreza que se instala em Portugal, principalmente, nas aldeias rurais, o povo, em princípio, permanece estagnado, até que ocorra a Revolução de 74. Mas, pelo que se nota, esta revolução mudou a vida de alguns poucos, pois, a grande maioria continuou na mesmice de antes.

Esta questão fica clara na obra que se serve como objeto de estudo, pois o movimento de ação no vilarejo é unilateral e desigual, ou seja, agem por si e para si e tudo que acontece naquela comunidade gira em torno dela mesma. Na concepção de Hegel (2000: 127), "o agir tem duplo sentido, não só enquanto é agir quer sobre si mesmo, quer sobre o Outro, mas também enquanto indivisamente é o agir tanto de um quanto de Outro", mas a ação não se processa dessa maneira no vilarejo. Os aldeões não agem sobre si mesmos, pois continuam confinados em uma espécie de "casulo" construído por eles mesmos, sem buscar, por meio de seu trabalho" a possibilidade de serem livres; não conseguem, por conseqüência, agir sobre o outro, uma vez que o confinamento causa uma certa estagnação no seu tempo e em si mesmo.

Ainda na Vilamaninhos é possível verificar essa mesma dialética do Senhor e do Escravo entre as personagens. Referindo-se aos casais que compõem a narrativa, observa-se que há uma relação de superioridade e de inferioridade, por exemplo, entre Pássaro e Branca Volante. Isso se processa, talvez, por estarem inseridos em uma sociedade tipicamente patriarcal, em que o homem detém o poder, ditando as regras, e a mulher simplesmente obedece. Pássaro Volante exerce seu poder sobre Branca Volante, e ela, nesta condição, apresenta-se como escrava do lar,

\footnotetext{
1 Este não faz referência ao regime de trabalho assalariado revelado por Marx nos "Manuscritos EconômicoFilosóficos" de 1844, em que o trabalho contribui para a escravização e alienação profunda do homem moderno. Mas, sim, remete ao conceito de trabalho citado por Hegel, que se apresenta de maneira diferente daquele que se constitui na teoria de Marx. Aqui o trabalho forma e liberta, elevando o ser dominado acima de sua "singularidade egoísta", um serviço para outrem, um trabalho que visa a uma alteridade.
} 
vivendo para atender aos desejos de seu senhor, no caso o marido, em prol do conforto dele próprio.

Assim como na dialética de Hegel, Branca, quando obedece aos demandos de seu marido, acaba se transformando, deixando vir à tona um dom (o de adivinhar e o de prever o futuro) que estava adormecido. Em Hegel, o mundo do Escravo é o mundo da existência natural que ele transforma com o seu trabalho para atender aos demandos do senhor, pois o escravo depende da satisfação deste Senhor para continuar vivendo. Esta transformação ocasionada pelo trabalho do escravo garante ao Senhor certa comodidade, já que o Escravo se dispõe a servi-lo no que precisar e isso faz com que o Senhor desconheça os rigores do mundo material. Desse modo, Pássaro Volante não se pretende na condição de senhor "em-si", uma vez que na realidade não é ele quem dita as regras. Ele só se reconhece como tal pela consciência de Branca, que, primeiramente, encontra-se na condição de ser para o outro, seu marido. Mas ela, com seu dom de prever o futuro, metaforicamente, tem tudo ao alcance das mãos, até mesmo o futuro do próprio marido.

Entretanto, observa-se que Branca, na condição de dominada, sente a necessidade especificamente humana de transcendência. Sendo assim, acaba deixando a situação que remete a uma inferioridade em relação a Pássaro para ocupar a posição de dominadora. Isso mostra que algo foi conquistado por ela, a sua liberdade. Esta liberdade reside, em primeiro lugar, na experimentação do medo e foi este temor absoluto que levou Branca à submissão. Mas a submissão de Branca pode ser considerada como um começo de sabedoria, pois, por meio desta, aprendeu que não é possível, na sua singularidade, afrontar ao senhor. Desse modo, aliada a esses poderes, Branca consegue se impor diante do marido.

Este espaço conquistado por Branca diante do marido pode estar atrelado ao que Hegel chama de trabalho. Por meio deste trabalho, Branca constrói a efetiva independência e autonomia, que lhe apontam a possibilidade concreta de ser livre, de atingir a liberdade que reside no domínio de si mesma.

Esta dialética também pode ser observada na relação entre as duas Carmens (a Rosa e a Parda, mãe e filha, respectivamente) e a comunidade de Vilamaninhos. O comportamento delas, evidencia uma superioridade, pois não se envolvem nos problemas corriqueiros que as circundam, isolando-se em suas casas. Por exemplo, no momento em que ocorreu o episódio da cobra voadora, elas estavam confinadas em casa e só tomaram conhecimento do acontecido 
quando Jesuína Palha (a porta-voz da comunidade) foi até a casa delas para saber o motivo pelo qual elas não estavam presentes. A não comunhão dessas personagens com o prodígio mostra que não estão no mesmo nível de consciência que as outras personagens, pois não participam das intrigas que compõem o discurso dos outros habitantes do vilarejo. Às Carmens pode-se atribuir essa condição, pelo fato de se apresentarem com uma consciência que pretende sair de seu estágio natural para que, talvez, possam evoluir. Elas parecem ter consciência de que os acontecimentos que se passam no vilarejo não irão levá-las a lugar algum. Daí a falta de interesse delas pelos assuntos corriqueiros que envolvem os vilamaninhenses.

Expectativas são criadas pelos "prodígios", com relação à chegada dos soldados, por exemplo, e também quando se remete ao retorno da cobra voadora, mas estas expectativas não levam a nada. O que deve ser levado em consideração é um agir que se efetiva por meio de ambas as consciências (entre soldados e camponeses) e não um agir isolado da consciência, como acontece na Vilamaninhos. Este tipo de consciência isolada se transforma no que Hegel vai chamar de consciência infeliz, pois esta não tem condições de efetivar sua liberdade.

A consciência infeliz apresenta-se, em Hegel (2000: 140), como "a consciência-de-si como essência duplicada", como natureza dividida. Neste momento, a consciência revive na intimidade dela mesma a divisão sofrida e desigual que caracterizou a relação Senhor e Escravo, passando a consciência a identificar-se ora com um, ora com outro, sem poder alcançar o repouso na unidade. Inicialmente a consciência infeliz é apenas a unidade imediata das duas consciências-desi, mas estas consciências não são similares e sim opostas, contraditórias. Uma delas é mostrada como essência (consciência simples e imutável) ao passo que a outra se apresenta mutável de várias formas. Uma luta se trava entre essas consciências e daí partem na ascensão rumo ao mutável, mas tal ascensão é essa mesma consciência (uma vez que se trata de uma única consciência, consciência infeliz, que está cindida em duas).

A infelicidade não é propriamente um sintoma cultural, mas trata-se de um dilaceramento interno à própria consciência, dividida, duplicada entre um 'em-si' e um 'para-si'; entre sua singularidade e sua universalidade; entre o mundo do ser e da vida, de um lado, e o mundo da consciência, de outro; entre a substância e o sujeito. Em outras palavras, "a consciência infeliz é uma subjetividade em busca de sua unidade" (HYPPOLITE, 1991: 176). Esta unidade, na filosofia hegeliana, não é apenas uma tênue esperança, é uma certeza, pois se observa que por mais cindida que esteja à consciência sempre estará rumo à superação para atingir a reconciliação 
no final do processo, num "conceito do espírito que se tornou [um ser] vivo e entrou na [esfera da] existência" (HEGEL, 2000: 140).

Desse modo, a consciência infeliz, na concepção hegeliana, tem uma conotação positiva, pois ao passar por este momento crítico que a infelicidade proporciona, o indivíduo, na realidade, está buscando sua unidade para posteriormente reconciliar-se consigo mesmo no absoluto. Esta consciência, mesmo contraditória "em si” e "para si”, sempre está a caminho de vir-a-ser espírito. Sendo assim, o processo alienatório em Hegel não se efetiva.

Em se tratando de Vilamaninhos, pode-se notar que os habitantes do vilarejo permanecem no imutável, primeiro estágio da consciência infeliz. Nesta primeira modalidade, tratada por Hegel como "pura consciência", a consciência infeliz não se relaciona com o seu objeto como pensante. Ela apenas caminha na direção do pensar, mas não se concretiza como conceito. Verifica-se, na narrativa de Lídia Jorge, que os camponeses tentam decodificar o que os soldados anunciam, mas não conseguem captar a essência do discurso dos combatentes, apenas sentem e ao sentirem acabam caindo de volta em si mesmos, permanecendo naquele estado de enclausuramento. Nota-se que os vilamaninhenses estão cindidos de sua essência imediata e, neste sentido, a alienação se opera, pois colocam a sociedade e a cultura como elementos exteriores a eles. Eles vivem como se estivessem à margem da sociedade e de tudo que advém dela.

A consciência infeliz no romance de Lídia Jorge ocasiona no povo do vilarejo uma falta de perspectiva. Após a partida dos soldados o vilarejo ficou em total decadência,

As lagartixas postavam-se esgalgadas como se fossem donas de todos os muros. [...] Atrás das casas as oliveiras estavam cinzentas como se fossem mariolão do mato. Mas sem flores. [...] E as cavalariças. Sabia-se. Tão cheias de palha como se fossem só para galinhas. Uma espera (JORGE, 1982: 159).

Esta situação deplorável em que o vilarejo se encontra é conseqüência da estagnação que tomou conta da vila. Pelo que se pode notar, a partida dos soldados sem uma explicação precisa, no que se refere ao desaparecimento da serpente voadora, contribui, ainda mais, para a manutenção dessa situação. Nota-se que há, no discurso dos vilamaninhenses, um tom de decepção, pois talvez acreditassem que os soldados fossem os únicos capazes de fazê-los 
recuperar a consciência de si e, quem sabe, se valendo das palavras de Hegel (2000: 142), proporcionassem ao povo do vilarejo o encontro consigo mesmo no imutável.

Depreende-se que os soldados podem representar, na narrativa, uma espécie de divindade superior, que talvez remeta a um Deus (Imutável e Universal), pois os habitantes da vila vêem estes soldados como seres quase sobrenaturais, "seres saídos do céu, e vindos de outras esferas" (JORGE, 1982: 152). Mas a chegada dos soldados indica que não há condições de integração entre eles e o povo da vila, pelo menos de imediato, pois os soldados saem do vilarejo surpresos com a realidade social que descobrem em Vilamaninhos, tanto que um deles advertiu "registramos que nesta terra ainda se gosta de milagres" (Ibidem: 157). Logo após a partida dos soldados, paira sobre a cidade um silêncio, "como se o silêncio do povoado fosse um luto" (Ibidem: 159), e agora “O futuro é o presente a andar lentamente para trás” (Ibidem).

Como já se afirmou no início deste capítulo, é possível que o drama de consciências focalizado em $O$ Dia dos Prodígios esteja, de algum modo, relacionado com o longo período ditatorial em que a população portuguesa sofreu grandes prejuízos de toda ordem. Ao que parece, os vilamaninhenses ainda se comportam como se vivessem no contexto do regime salazarista. Afinal, como disse Fernandes (1962: 177), foram "34 anos de infâmia, de crueldade, de despotismo, de enriquecimento para uns poucos e miséria para os outros todos, 34 anos de sofrimentos, de vergonha, de ausência de liberdade". Neste período, os indivíduos eram educados para não contestar, pois Salazar implanta em Portugal um regime que "prega a ignorância do homem, a sua incultura, a sua miséria, para melhor poder governá-lo" (Ibidem: 179).

Nesse sentido, parece estar presente na narrativa, desde o início, a idéia de que a educação será o caminho para a realização do projeto revolucionário. Só pela educação será possível aos portugueses apostarem "nos valores exactos".

Para Hegel o conceito de educação esta relacionado ao homem e o homem é o que ele faz de si mesmo. Obviamente não há o controle ou a consciência absoluta de tudo o que o homem possa ser e fazer, pois as conseqüências de um ato humano não podem ser determinadas. Mas, assim mesmo, o homem é sua própria atividade, a formação empreendida e recebida, em outras palavras, a sua educação. Isso não significa que o homem é determinado totalmente pela natureza, pois ele se constrói e ao construir-se realiza o espírito. Desse modo, o homem participa da vida do espírito para atingir a liberdade. A liberdade, para Hegel, é atingida por um processo que exige o "desensimesmamento do sujeito", ou seja, o indivíduo sai de si para encontrar-se e 
reconhecer-se no outro e isso possibilita o encontro consigo mesmo e, consequentemente, a sua ascensão para atingir a liberdade.

Para que se processe a formação educativa do individuo, é imprescindível que ele, de acordo com Hegel, interaja com o meio, pois a exterioridade é o que possibilita a educação. Quando o indivíduo se abre à exterioridade, acaba inserindo-se no espaço da coletividade e neste espaço afirma a sua história, sua condição de povo, pois a história nunca é atividade isolada e exclusiva de indivíduos. Desse modo, cada homem educa-se dentro de seu povo, pelo que faz pensando em si, mas que, na realidade, é o pensar de um povo, do seu povo. A participação do indivíduo na vida de seu povo determina o envolvimento com a totalidade dos indivíduos expressa na atuação do indivíduo particular. De tal forma, o comportamento distintivo do indivíduo marcado pela inserção e consonância com o espírito de seu povo denota seu crescente nascimento do natural ao espiritual. Assim, a educação proporciona o segundo nascimento do indivíduo, por torná-lo autônomo e senhor de si no convívio com seu povo. A autonomia é uma conquista do indivíduo, pois este precisa aderir à proposta de seu povo e renunciar a particularidades e exclusivismos. E esta adesão e renúncia não se processam no âmbito da natureza reduzida, no em si de si mesmo, ou seja, na clausura de uma existência determinada. Portanto, a educação diz respeito à existência de indivíduos e de como estes vêm a ser individualidade coletivizada e coletividade individualizada.

Mas os contratempos são inevitáveis, pois o desenvolvimento do espírito não é harmônico nem retilíneo, ou seja, não exclui o conflito e não avança somente pelos sucessos. O auge dos contratempos que o espírito encontra na sua trajetória encarna-se na alienação do espírito. Esta ocorre no início, no momento em que o espírito sai de si, pois é ai que ele pode olhar para si, perceber-se e, mais do que isso, pode ocorrer, como postulou Hegel, o aprendizado do espírito sobre si mesmo. Por esse motivo, o início é o mais abstrato, o mais inconsistente e, exatamente neste momento a realidade precisa ser entendida, segundo Hegel, como um resultado. Neste sentido, o processo de alienação aqui tem uma conotação "natural" do espírito que tende ao outro de si, à sua saída.

No que se refere a Vilamaninhos, observa-se que os habitantes do vilarejo encontram-se no estágio primeiro da consciência, ou seja, a alienação ali, assim como em Hegel, tem uma conotação "natural" do espírito. Mas isto ocorre de uma maneira diferente, pois os aldeões não 
tendem ao outro, como acontece na teoria hegeliana, e, pelo que parece, também não se projetam neste outro para que ocorra o aprendizado sobre eles mesmos.

A maneira pela qual os camponeses foram educados, seguindo os preceitos de uma educação descontextualizada (educação esta que não seguiu nenhum outro modelo de educação que garantisse a formação de homens guiados pela razão e pelo espírito) e regidos por um ditador que tinha como principal objetivo o aprisionamento da consciência de um povo guiado por ele, também contribuiu para que ficassem estagnados naquele "estágio natural" de consciência e, conseqüentemente, para que continuassem confinados no vilarejo e entregues ao marasmo.

A educação da população, durante o governo de Oliveira Salazar, não se caracterizou por algo construído pelo homem na sua relação com o outro, como seria a educação que Hegel defende, mas mostra-se como algo que é sutilmente imposto pelo ditador, e que deve ser seguido sem contestações.

Igualmente opressora e discriminadora foi a instituição, durante o Salazarismo, de dois tipos de educação: uma destinada só a rapazes, MP (Mocidade Portuguesa), e outra direcionada exclusivamente às moças, MPF (Mocidade Portuguesa Feminina). Estas organizações tinham como objetivo preparar as moças e rapazes para a vida, cada um a sua maneira: os rapazes transformavam-se em cidadãos aptos à defesa da pátria, e as moças convertiam-se em excelentes esposas.

A MP almejava ser uma organização de toda a juventude, escolar e não escolar. O desejo dos ditadores era que todos os jovens de qualquer parcela do território português fizessem parte desta organização, pois esta era o espelho do Exército e das almas da juventude de Portugal e compreendia a sua preparação educativa nas modalidades seguintes: formação pré-militar; atividade cívica e serviço social. Na realidade, de acordo com Arriaga (1976: 104), a MP pretendia preparar soldados e,

impregná-los dos ideais nacionalistas de um regime ditatorial que não olhava a meios para atingir os fins. E como não seria fácil convencê-los pelo voluntariado, havia que laçar mão de todos os mecanismos repressivos que os levassem a ingressar nas fileiras da organização salazarista. Toda uma cobertura legislativa estabelecia penalidades às infrações e, sobretudo insinuava que as resistências seriam detectadas e que as fugas teriam imediata contrapartida ao nível do aproveitamento escolar. 
A MPF destinava-se a trabalhar para a formação completa da jovem portuguesa, visando à sua missão futura de esposa e de mãe. Além disso, o Regulamento da MPF instituía que a educação social devia cultivar nos filhos o gosto da vida doméstica e o de servir o Bem Comum, ainda que com sacrifício. Na organização, promovia-se uma educação dita humanista, traduzida em formação de caráter, que pretendia o desenvolvimento da capacidade física, cultura do espírito e devoção ao serviço social. Nesta educação formal, também,

ensina-se a viver o amor de Deus, da Pátria e da Família através de uma ativa e vigilante valorização pessoal, que permita mais tarde à mulher cumprir em plenitude a sua missão, integrando-se conscientemente nas realidades do tempo em que é chamada a viver (ARRIAGA, 1976: 115).

Nota-se, pelos lemas que integram a MPF (Formação a uma mentalidade dita exclusiva da mulher portuguesa; Formação moral, religiosa e nacionalista) e a MP (Formação da juventude para exercer uma atividade cívica para o fortalecimento de sua dedicação à Pátria; Formação da educação pré-militar, destinada à preparação para a defesa nacional), que estas organizações se constituem em verdadeiros modelos de alienação, pois tanto as moças, quanto os rapazes eram educados para obedecer às ordens dessas organizações sem direito a nenhuma contestação. A obediência era necessária, segundo os comandantes das organizações, para que se formassem verdadeiros "cidadãos" portugueses e para que estes pudessem servir à Pátria com dignidade. Esta servidão acabava por converter-se em escravidão e isso fazia com que o povo português ficasse cada vez mais submerso em sua ignorância.

Com o advento destas organizações, o governo de Salazar mostra-se como a expressão da desigualdade, pois o autoritarismo daqueles que estão no poder sobre aqueles que constituem as camadas populares está intrinsecamente presente nas relações interpessoais. Por conta disso, o povo era cruelmente oprimido, humilhado e obrigava-se a ser submisso, pois aqueles que se rebelavam contra a ditadura eram esmagados pelo ditador. A opressão era tão fortemente imposta que até mesmo nos mais humildes e distantes vilarejos os padres em suas paróquias "ensinavam" que era pecado pronunciar a palavra "liberdade".

Esta forma de "educar" adotada por Salazar não parece ser a mais adequada, pois só contribui para uma alienação profunda do indivíduo e, conseqüentemente, para o não reconhecimento de si mesmo. Tendo em vista, que o homem se constitui na sua formação 
educativa é possível notar que o indivíduo que presenciou a ditadura salazarista não participa da vida do espírito. Em outras palavras, sendo o espírito o resultado de um processo que se expressa na liberdade, é possível verificar que o indivíduo que se insere no regime de Salazar não goze de sua liberdade. Talvez, ele nem possua esta liberdade, pois ninguém que foi influenciado por uma ditadura, que defende a formação de uma mentalidade que propicia a construção de uma consciência alienada, consegue atingir a liberdade de forma absoluta.

Salazar, não somente no que se refere à educação, mas em seu governo como um todo, inspirou-se na ditadura de Mussolini (aquele que governou com poderes ditatoriais a Itália, entre 1922 a 1943, autodenominando-se Duce, que significa em italiano "o condutor") e declarou isso em uma entrevista fornecida a António Ferro em 1932: "A nossa ditadura aproxima-se, evidentemente, da ditadura fascista no reforço da autoridade, na guerra declarada a certos princípios da democracia, no seu caráter acentuadamente nacionalista, nas suas preocupações de ordem social" (TORGAL, 2001: 392). Isso mostra que a sua educação foi inspirada no autoritarismo que tinha como principal objetivo formar espíritos cujas consciências se desenvolvessem na infelicidade.

Ao passo que Hegel recebeu em sua educação muita influência do mundo grego, pois, para ele, o homem derivado do mundo grego é aquele que se embrenha pela eticidade, pela razão, pelo espírito despojado de suas contingências. O conhecimento dos clássicos contribuem para que o indivíduo deixe seu "estágio natural" e se depare com as riquezas do espírito. Mas, em se tratando de Vilamaninhos, os habitantes que vivem ali permanecem em seu "estágio natural", quando o espírito ainda se encontra em seu estágio primeiro.

$\mathrm{Na}$ Vilamaninhos, pelo que se pode observar, o indivíduo não se apresenta como fruto de sua época e as atitudes daqueles habitantes não se processam a partir de sua realidade, pois verifica-se que há, por parte das personagens, um retorno constante ao passado no qual eles, talvez, esperam encontrar o paraíso perdido. De acordo com Hegel, o espírito não deve prenderse ao passado, pois assim nunca deixará o seu estágio natural. Mas os camponeses de Vilamaninhos continuam vivendo no vilarejo em estado de confinamento e entregues ao marasmo.

Assim, seria preciso que os habitantes do vilarejo conseguissem situar-se em seu tempo e espaço e pudessem estabelecer como meta a criação de uma eticidade que os confirmasse como cidadãos condutores de si mesmos. Só assim eles poderiam se preparar, não simplesmente para 
uma vida, mas, para uma vida qualificada, movidos por objetivos que transcendem o aqui e o agora, inserindo-se no contexto do espírito, no resultado das produções humanas. 


\section{CAPÍTULO III}

\section{TRAÇOS DA LINGUAGEM CAMPONESA}

A constatação de que a linguagem se realiza por meio de um processo mental de manifestação do pensamento e de natureza essencialmente consciente, significativa e orientada para o contato interpessoal, torna evidente que o modo de pensar e falar de determinadas comunidades estão indissociavelmente ligados. Desde a Antigüidade, a estreita relação e dependência entre pensamento e linguagem tornaram-se lugar comum na filosofia e, desde então, tendo em vista essa mútua dependência entre o refletir e o dizer, pode-se considerar a língua como o espírito de um povo.

A linguagem, meio de expressão de uma sociedade, se constitui como representação do mundo e do pensamento; é ainda instrumento de comunicação, forma de ação ou interação entre falantes. Desse modo, o mundo real constrói-se, inconscientemente, sobre os hábitos de linguagem de um determinado grupo social. As experiências vividas em sociedade desenvolvemse pela influência que a linguagem exerce sobre os indivíduos. Evidentemente, as influências externas também contribuem para a formação deles, mas cabe principalmente à linguagem desenvolver esse papel.

Em síntese, considera-se a linguagem como instrumento para que o homem estabeleça vínculo no tempo e determine os tipos de relações que deseja manter. Enquanto língua, é uma 
instituição atual e um produto do passado, pois nenhuma sociedade jamais a conheceu de outro modo que não fosse como produto herdado de gerações anteriores.

Em O Dia dos Prodígios, a linguagem utilizada pelos vilamaninhenses nas trocas conversacionais é a popular, aquela que se processa no cotidiano das sociedades e que está presente nas falas da população da aldeia. Trata-se de uma linguagem própria de uma comunidade rural imaginária, em que convivem indivíduos sofridos, em condições totais de abandono por parte das instituições públicas, à margem dos avanços sociais dos grandes centros urbanos. Eles vivem praticamente isolados, apesar do avanço das comunicações e da ocorrência de uma revolução, no caso a dos Cravos de 1974. Esse isolamento decorre da desinformação e do despreparo dos aldeões, e isso também contribui para o não entendimento do mundo moderno, como ilustra o seguinte fragmento: "Era o novo século que estava a começar. Diziam. Muito atrasado nas nossas bandas. Uma era de coisas rápidas, toda feita de rodas e alavancas..." (JORGE, 1982: 52).

Como se vê, o povo de Vilamaninhos não se relaciona com o restante do mundo, e sua vida permanece restrita apenas ao que acontece naquele local, entre aquelas pessoas. Nada se sabe sobre o mundo além de Vilamaninhos. Situações que, em sociedades civilizadas, seriam pouco relevantes, em Vilamaninhos tornam-se muito importantes.

Nesse universo, o privado confunde-se com o público, devido ao fato de os acontecimentos estarem restritos à vida de cada membro da pequena sociedade da aldeia. Há um interesse muito grande pela vida de todos, o que não quer dizer que esse interesse seja para beneficiar alguém. A invasão da privacidade alheia é uma constante na Vilamaninhos e isso se dá por mera curiosidade, apenas com o pretexto de preservação dos bons costumes e de auxílio ao próximo.

Nota-se que, para estabelecer a comunicação, os aldeões se valem de uma forma de língua que tem seu próprio sistema léxico, sintático e fonético, e é usado num ambiente mais restrito que a própria língua. Trata-se de um dialeto que é muito peculiar ao povo daquele vilarejo e que está inserido em uma língua maior. Para especificar ainda mais, observa-se que há a presença muito forte do idioleto, sistema lingüístico que se constitui como forma local de comunicação, de um único indivíduo ou grupo social, que reflete as características sociais de um povo, os estímulos a que foi submetido, a sua biografia. A presença do idioleto, neste caso, se constitui por meio do embaralhamento dos diversos níveis de fala que compõem o discurso das personagens. A 
presença desse discurso da oralidade acaba suavizando as hierarquias de falas e, ao mesmo tempo, conduz toda a narrativa para o espaço mais simples das coisas do dia-a-dia.

Em outros momentos, há um ondear de vozes, que afirmam um discurso próprio. Isto sugere que o narrador às vezes sujeita-se aos demandos de uma voz superior à dele, a voz da comunidade do vilarejo. Há, porém, uma supremacia de voz que fala sobre a voz que conta.

Eu. Jesuína Palha. Eu

andava a dar fogo ao forno

quando ouvi estes três des-

graçados a pedirem acuda.

Mas não deixi que pedis-

sem duas vezes. Pus os to-

jos de lado, salti por cima

da parede, pegui uma cana

comprida que ali tinha à

mão, e fui-me para onde

estes três vai não vai tem-

tavam mata-la. Sem com-

seguirem os probrezinhos.

Ah meus amigos. Ah ca-

rago. Já a família desta

Toda a gente vinha cor-

terra estava chegando ao

rendo a ver a cobra. Che-

largo. Ali, Eles que digam

gui eu nessa altura. E vi-

Estavam todo suadinhos

nha tão cega, que nem me

de tanta pedrada sobra a

apercebi do que via.

magana.

(JORGE, 1982: 22).

Já à primeira vista se observa que, neste fragmento, o texto está organizado em forma de colunas e não é gratuitamente que isto ocorre. Esta disposição possibilita que algumas personagens se expressem concomitantemente. Tem-se aqui o relato dos circundantes, disposto à direita, simultâneo ao relato de Jesuína Palha disposto à esquerda. É possível notar, já no prólogo, que a autora pretende preparar o leitor para uma nova forma de expor o texto, quando deixa claro que as personagens devem falar cada uma a sua vez; quando menciona o desentendimento que, 
provavelmente, é representado, na narrativa, pelo embaralhamento de falas. Ainda seria interessante apontar que esta introdução, pela forma como se apresenta, remete a um prólogo teatral, pois se trata de um diálogo inicial, entre personagens e autora, que se mostra como um elemento elucidativo do tema que vai se desenrolar na trama.

Quando se mergulha no interior da narrativa, é possível notar que, em Vilamaninhos, as condições de comunicação são precárias, tanto no que se refere aos meios de comunicação, uma vez que o único veículo de comunicação que tinham era o rádio de Pássaro Volante, quanto no que se refere ao processo que envolve a troca informacional que permite a interação entre pessoas.

Analisando o segundo aspecto e fazendo uma relação com a comunidade de Vilamaninhos, pode-se notar que, na realidade, a comunicação não se processa naquele vilarejo. Quando há uma tentativa de diálogo, percebe-se que o desentendimento entre os habitantes se evidencia ainda mais. De acordo com Bakhtin (2004: 14), isto ocorre pelo fato de a "fala estar indissoluvelmente ligada às condições de comunicação, que, por sua vez, estão sempre ligadas às estruturas sociais".

Mas a ausência de sintonia presente nessa tentativa de comunicação, essa falta de articulação, explícita na fala das personagens, pode ser reflexo da estrutura arcaica do lugar.

Ao escolher representar em sua obra uma sociedade rural, não somente pela linguagem utilizada, mas também pelo modo como se comportam os habitantes do vilarejo, Lídia Jorge constrói uma ação de resistência às tendências centralizadas, fazendo uma crítica à marginalização dos que vivem fora dos grandes centros. Ao expor os hábitos e costumes daquele povo, a escritora faz uma descrição do discurso utilizado por eles, evidenciando o dialeto regional, seus jargões e as palavras que, muitas vezes, são pronunciadas de maneira diferente, tendo como referência os aspectos gramaticais da norma-padrão culta dos centros urbanos desenvolvidos.

Há, na narrativa, uma mescla de narração literária com oralidade camponesa. Quando a autora deixa aflorar esse tipo de fala, expressa pelas personagens, nota-se que se cria um debate sutil com as formas escritas da narração literária tradicional para produzir um efeito rural. A exemplo disso, tem-se, no discurso da personagem Jesuína Palha, o uso da linguagem coloquial e rural: "Mas, não deixi que pedissem duas vezes. Pus os tojos de lado, salti por cima da parede, pegui uma cana comprida que ali tinha à mão" (JORGE, 1982: 22). 
Esta marca da oralidade, tão presente no texto de Lídia Jorge, também pode ser percebida por meio das preocupações e pressentimentos denunciados pelas personagens, pois esses são traços que podem pontuar a expressividade da língua: "E Jesuína Palha disse. Este tempo traz-me pressentimentos ruins. E Manuel Gertrudes disse. A mim lembra-me os frios que passi em Flandres, de borco sobre a terra,..." (JORGE, 1982: 68); "Eu tenho um grande pressentimento. Que uma nova maravilha vai acontecer sobre o redondo do mundo. Uma gente nova vai povoar a terra" (Ibidem: 86).

Neste discurso se aglutinam, alegoricamente, a falta de perspectiva, de identidade e, ainda, a falta de uma linguagem coesa e coerente, que era expressa, a todo o momento, por frases de efeito, sem sentido:

Manuel Gertrudes disse. Se Macário estivesse acordado, as quadras que não cantaria. E Matilde disse. À cobra/ E Manuel Gertrudes disse. Sobre que haverá de ser. E João Martins disse. Se ele visse Carminha a passar, ou pelo menos a sua voz, já as quadras seriam outras. E José Maria, o cantoneiro, disse. Antes as de amor (Ibidem: 37).

Observa-se que há uma fragmentação quando a autora apresenta a fala das personagens como anotações soltas, como se fossem imagens isoladas. Isso transforma o diálogo das personagens em monólogos que, aparentemente, não levam a parte alguma. Desse modo, a narrativa de Lídia Jorge caracteriza-se como romance fragmentário, pois, ao se dividir em blocos, acaba promovendo "cortes" na realidade. Essa fragmentação procura acentuar, em O Dia dos Prodígios, o princípio de um mundo pobre de sentido, pois os indivíduos que habitam na vila não são capazes de visualizar o todo, por não perceberem nada além de seu pequeno mundo.

Este ambiente arcaico, marcado, entre outras coisas, pela linguagem e pelo comportamento dos aldeões, é indicativo do existir miserável daquele povo, da falta de perspectiva, o que justifica a espera e o adiamento de seu próprio destino. Essa condição está diretamente ligada à opressão ditatorial e ao peso da tradição, pois ambos instigam a supervalorização do passado, fato presente na cultura do povo português, e induzem à não aceitação do progresso.

Stuart Hall (2001: 14-15), citando Anthony Giddens, afirma que: 
nas sociedades tradicionais, o passado é venerado e os símbolos são valorizados porque contêm e perpetuam a experiência de gerações. A tradição é um meio de lidar com o tempo e o espaço, inserindo qualquer atividade ou experiência particular na continuidade do passado, presente e futuro, os quais, por sua vez, são estruturados por práticas sociais recorrentes.

Importante ressaltar que esta veneração do passado não é uma característica própria do povo português, é algo que surgiu dos povos da Antigüidade, próprio, de certa forma, do espírito céltico, o espírito que aguarda. Essa espera causa, na sociedade portuguesa, uma espécie de desânimo em imaginar o que está por vir, para além do imediato. Desse modo, de acordo com Gomes (1993), o agir passa a ser algo instintivo e não programado, pois os lusitanos acreditam que, ao programar, o homem coloca o ser à frente do existir, e isso não é o que se pretende. Eles se colocam sempre um passo atrás do futuro e preferem esperar pelos acontecimentos para verem os resultados.

Nota-se, ainda, no esforço em manter e trazer à tona aquilo que está ultrapassado, o desejo de que a voz da tradição prevaleça sobre as transformações da modernidade. O povo do vilarejo supervaloriza os acontecimentos de um tempo que ficou para trás, tentando buscar ali um refúgio para sua sobrevivência. Esse recordar oferece aos aldeões a oportunidade de se reportarem a um tempo sem crise. Mas o recuo constante a um passado remoto pode resultar na estagnação do presente, ocasionando um afastamento cada vez maior em relação à realidade. O passado é tão enaltecido que o presente se torna obscuro para os camponeses, a ponto de não serem capazes de avaliar as conseqüências do movimento revolucionário de 74 . Devido a essa força do passado, o presente se torna um tempo vazio, povoado de idealidades sem propósito, como, aliás, a experiência da Revolução demonstra de modo flagrante.

O culto doentio ao passado tem, também, como conseqüência a descaracterização de um povo, pois aceitam passivamente as condições precárias de sobrevivência em que estão inseridos, refugiando-se em universos paralelos de alienação, que termina por descaracterizá-los enquanto seres humanos.

Parece que essa descaracterização, no romance de Lídia Jorge, inclina as personagens a uma perda da identidade por viverem confinadas naquele vilarejo, sem contato com o que está exterior à vila e sem perspectiva de progresso. Observa-se que lhes foi impingido um modo de ser 
e agir que os caracteriza como um povo que perdeu o hábito de refletir, desconhecendo, conseqüentemente, a essência de sua identidade.

Uma das marcas do linguajar utilizado pelos camponeses é o uso de comparações. Quando descrevem algum fato substituem, com freqüência, os adjetivos, estabelecendo um paralelo com características de animais, suas fisionomias e seus comportamentos. São comuns também as alusões a situações cotidianas compartilhadas pelos vilamaninhenses, como recurso empregado com o propósito de descrever ou especificar algo:

Então Manuel Gertrudes disse. Ah Macário. Ah punhão. Como é possível que eu venha aqui para te falar do que acaba de suceder, e te encontre deitadinho como um animal motes. E depois já de cócoras disse. Dorso curvado. Nem um capachinho debaixo da cabeça, nem um paninho a cobrir-se das moscas. Aqui tombado como não sei o quê. Vinha para te dizer o que acaba de acontecer a todos os habitantes. Como um aviso. E vai daí, vejo-te aqui espernegado no chão, sem te mexeres como se estivesses morto pelo flato. Se não afegasses quando te ponho a mão a boca e nas ventas, assim rodeado de bichos, havia de pensar que nem mais mexerias no bandolim (JORGE, 1982: 15).

O desconhecimento vocabular dos camponeses faz com que eles se sirvam de imagens para representar o real. Eles possuem conhecimentos plenos acerca da natureza, do seu habitat, por isso os elementos desse meio são empregados para expressar sua concepção de mundo. Sob o ponto de vista dos aldeões, o uso que fazem da língua é perfeitamente adequado, porém, sob a ótica daqueles que vivem fora do vilarejo, essa utilização da língua é simplesmente retrógrada e arcaica. Isso ocorre pelo fato de os camponeses viverem em uma espécie de sociedade medieval, marcados por um efeito paralisante, caracterizando a falta de mobilidade social.

Tendo em vista que a oralidade é a forma de comunicação empregada no romance de Lídia Jorge, interessante seria fazer uma explanação acerca deste tema. De acordo com Marcuschi (1986) a área da oralidade, mais formalmente referida como a Análise da Conversação, se liga ao campo lingüístico e está voltada ao estudo da fala, das conversas, das trocas de informações entre indivíduos por meio de signos verbais orais, ou seja, pela palavra dita ou por sua representação. Na Análise da Conversação constata-se que há três elementos responsáveis pela organização do texto falado: aquele que se interessa pela unidade em que os turnos conversacionais se constituem, buscando pelos indícios de seus participantes e seus perfis; 
aquele que se interessa pela situação de conversação, isto é, o ambiente em que a cena comunicativa ocorre e suas implicações; aquele que se interessa pelas manifestações dos envolvidos no ato conversacional e os implícitos revelados pelas atitudes dos autores, ou seja, dos sujeitos que participam da conversa.

As expressões oralidade e conversação são empregadas como sinônimos, denominando a área do conhecimento que se preocupa com o estudo da fala e do comportamento dos falantes em um ato comunicativo. O falante, considerado o próprio sujeito do ato comunicativo, possibilita que se construa dele uma imagem. Ao se comunicar, o falante oferece indícios de sua forma de pensar; do modo de ser e de agir; de sua visão de mundo, captados não só por meio daquilo que é dito, mas também pela forma como se expressa, tanto por suas escolhas lingüísticas, tanto pelo seu comportamento. Desse modo, a fala revela o falante e expõe o seu ser.

Nem sempre revelada como manifestação lingüística voluntária e desejada, a fala não é decorrente unicamente dos interesses explicitados com racionalidade, ou seja, pode resultar mais da emoção que da razão. Em outras palavras, a fala não é sempre arbitrária (que não segue regras ou normas), embora sua formulação esteja condicionada ao sujeito que a enuncia. A atitude espontânea é um aspecto característico da fala, pois suas circunstâncias são consideradas imprevisíveis. Os eventos de uma conversação são incontroláveis. Isso ocorre pelo imediatismo presente na fala, pois a ação e a reação dos envolvidos no ato conversacional ocorrem imediatamente. Têm-se, então, indivíduos partícipes de uma conversa que precisam manter e garantir o ritmo das trocas conversacionais. Esse dinamismo de conversação pressupõe uma agilidade e essa aceleração, consequentemente, diminui a possibilidade de reflexão e de seleção das falas a serem ditas.

Existem muitos fatores que são importantes para o estudo da oralidade ou da conversação: o contexto, a circunstância, os interlocutores (enunciador e enunciatário) e a relação que os envolve, os papéis sociais desempenhados. Esses fatores mostram que a fala se realiza no momento presente e real, mas sabe-se que o agora decorre de um momento anterior e constrói o porvir em uma rede complexa de envolvimentos.

Este é um aspecto que está presente em O Dia dos Prodígios, pois a autora procura identificar os traços de oralidade, expressivamente presentes no texto, para que possa analisar, por meio da fala das personagens e por meio da escrita, que a língua não é somente um recurso utilizado para caracterizar as personagens, mas também serve para revelar os problemas 
intrínsecos à existência humana (problemas estes que se referem às condições retrógradas que a Vilamaninhos está situada, marcada pelo distanciamento físico e cronológico, em relação aos grandes centros e ao estilo de vida contemporâneo à época do romance).

Sabe-se que, em O Dia dos Prodígios, a oralidade é fator fundamental na constituição da sociedade de Vilamaninhos, pois, pelo que se pode notar na narrativa, quase todas as personagens são analfabetas, exceto Carminha Parda e sua mãe Carminha Rosa. A linguagem literária serve para representar o discurso de um povo iletrado e distante do desenvolvimento sociocultural dos grandes centros.

Com isso, nota-se que os vilamaninhenses não possuem o domínio do código escrito, que favoreceria ao indivíduo o desenvolvimento em sua capacidade de inteligência, gerando conhecimento a ser aplicado na busca de soluções para os grandes problemas da humanidade. Ao aprender a língua escrita, o aprendiz faz uso de recursos mentais que propiciam a organização do pensamento. Isso é necessário para que se possa ter clareza mental. Ao mesmo tempo que exige recursos mentais, o aprendizado da escrita, desenvolve no indivíduo a possibilidade de ação crítica diante de seu meio social.

Por outro lado, o fato de uma sociedade estar exclusivamente ligada à oralidade não significa que o desenvolvimento humano se torne inviável e nem que o crescimento social fique impedido, pois, como advertiu Rocco (2001: 279-280) "nem toda a evolução do conhecimento humano se explica exclusivamente pelo surgimento e domínio cada vez maior e mais sofisticado de uma organização escrita". Contudo, o fato dos habitantes do vilarejo terem a oralidade como única forma de interação verbal, torna a interdependência entre os membros desta comunidade ainda maior. Devido a isso, os jogos persuasivos encontram grande campo de ação, pela falta de provas documentais que só podem ser obtidas por meio da escrita.

As capacidades de leitura e escrita propiciam ao indivíduo ampliar sua visão sobre tudo o que envolve a vida, pois ambas o colocam em contato com o mundo, fazendo com que ele se defronte com o novo, o diferente. A mudança ocorre de modo constante e é inerente a ele. Mas, ao se deparar com o inusitado, o indivíduo conhece e ao conhecer, o homem se transforma.

Nota-se, na comunidade de Vilamaninhos, que há uma impossibilidade de leitura e de escrita que escraviza os indivíduos daquele vilarejo àquilo que lhes é contado, tornando-os reféns de uma verdade que é divulgada pela tradição oral. As histórias registradas na mente de cada indivíduo, os fatos do passado e do grupo social como um todo, sempre recebem alguma 
contaminação pela subjetividade que é própria do homem. Por conta disso, as verdades de uma sociedade são repassadas sob o ponto de vista daquele que conta a história. E isso, provavelmente, é um dificultador para o indivíduo, pois o desenvolvimento de uma sociedade está relacionado à sua capacidade de entender o mundo e as diferentes maneiras de ser e existir de seus povos. A escrita exerce a função de transpor as barreiras geográficas. Quando isso não ocorre, em decorrência da não relação entre indivíduo e mundo em que está inserido, há a estagnação e o distanciamento social.

A estagnação é uma característica muito marcante na sociedade de Vilamaninhos, pois os vilamaninhenses se encontram completamente alienados do mundo em que vivem. Isto ocorre pelo desconhecimento que se instala no vilarejo em relação aos fatos históricos e políticos presentes em toda sociedade portuguesa, exceto naquele microcosmo denominado Vilamaninhos. Isto se processa por não haver uma interação entre os habitantes do vilarejo e o outro que pode estar fora do vilarejo. Ao que parece, só existe, como postulou Bakhtin (2004) um “eu-paramim”, aquele que só se constitui na relação consigo mesmo e não na relação com o outro. Desse modo, de acordo com Bakhtin (Ibidem) a relação dialógica não se processa no vilarejo. Mas, observa-se, na obra de Lídia Jorge, que há algumas situações de diálogos que se realizam internamente na narrativa. E estas falas podem expor mais do que os conteúdos verbalizados; expõe a ideologia de cada um.

Ao considerar que as falas produzidas por um sujeito são autônomas, a partir do momento em que são apresentadas e sujeitam-se a múltiplas interpretações, de acordo com os grupos de interação e seus conceitos, observa-se que a ideologia é um aspecto significativo que permeia o estudo da oralidade em $O$ Dia dos Prodígios. Isso se processa pelo fato da própria ação do indivíduo ser resultado de conceitos ideológicos nele embutidos durante sua existência. Sob essa perspectiva, como advertiu Santanna (2003), nota-se que as influências que constituem um indivíduo em seu pensar e em seu agir são manifestadas na interação que se estabelece entre homem e sociedade. Sendo assim, a cada indivíduo não se confere uma idéia particular, pois o interesse específico de cada ser humano representa, de fato, o interesse coletivo do grupo social em que está inserido.

Por meio da linguagem oral, o indivíduo, ao se expressar, faz uma exposição de suas crenças e valores. Esta amostra é, concomitantemente, manifestação e elemento constituinte da ideologia de um ser social (a ideologia não se efetiva de modo consciente, mas involuntariamente 
no indivíduo, como fator resultante do seu existir em sociedade). Em cada manifestação, verbal ou não verbal, estão presentes fatores da história de cada indivíduo, pois de acordo com Santanna (Ibidem: 25) nem sempre as ideologias apresentam-se através de uma linguagem verbal, mas também e principalmente por meio dos signos não-verbais.

Com isso, nota-se que a forma de linguagem que se utiliza no vilarejo para estabelecer a comunicação, predominantemente oral, exprime as convicções daquele povo, aquilo que pertence à história deles e que tem um valor significativo:

Chega-te aqui Esperancinha, senta-se nessa cadeira e tira o lenço da cabeça para ouvires o que ainda me lembro sobre a gente dos meus passados. Oh Esperancinha. O avô do avô, que comigo andou ao colo, nasceu das ervinhas. Encontraram-no dento dum balaio como se fosse uma mão cheia de figos para dar a porcos... (JORGE, 1982: 29).

É possível notar, por meio do discurso de José Jorge, que suas convicções são expressas por meio da fala, dos diálogos estabelecidos entre ele e sua esposa Esperancinha. Dessa forma é possível conhecer o indivíduo e ao conhecer o indivíduo conhece-se também a comunidade que ele pertence.

Considerando que em todo processo de interação social está implícita a ação persuasiva, observa-se que, no grupo social de Vilamaninhos, há um envolvimento entre as personagens, sujeitos falantes, em seus atos conversacionais. Isto pode ser observado por meio da personagem Jesuína Palha, pois impõe, a todo tempo aos habitantes da vila, o seu discurso, pelo fato de conhecê-los bem e saber como impressioná-los. Este é um aspecto importante do processo conversacional, pois o agir de modo convincente e o aceitar o proposto pelo outro, como é o caso dos vilamaninhenses em relação ao discurso de Jesuína Palha, exigem dos integrantes desse processo o desempenho de suas habilidades interacionais.

Dentro de uma sociedade, os indivíduos estão sempre investidos de papéis sociais. Ao identificar as ordenações do poder em um grupo social, ou seja, as hierarquias, os indivíduos identificam uma espécie de padrão a ser seguido com o intuito de alcançar um objetivo. $\mathrm{Na}$ Vilamaninhos é diferente, pois, pelo que parece, não há um padrão a ser seguido. Existe uma hierarquia que se constitui pelos níveis de consciência que cada personagem apresenta (as Carmens com relação à sociedade de Vilamaninhos; Branca Volante com relação ao marido, por 
exemplo), mas, ao que parece, não é algo planejado, as circunstâncias levaram essas personagens a desenvolverem um nível de consciência que caminha para uma evolução e não para a estagnação, como ocorre com a maioria que ali habita.

Pode ser que essas personagens evoluam, uma vez que já estão um passo à frente em relação aos outros. Mas o confinamento e a desesperança ainda perduram. Isto pode ser notado por meio da linguagem que utilizam, remetendo ao que faziam antes e que agora não fazem mais, pelo fato de estarem estagnados e parados no tempo,

Manuel Gertrudes disse. Antes o arreeiro trazia outro peixe. E o arreeiro disse. Antes toda a gente só falava da frescura dele [...] E Macário disse. Agora pouco se interessam pelo meu bandolim. Parece que andam a ouvir outra música. [...] Matilde disse. Antes vinha muitas vezes, mas Macário dizia coisas. E Macário disse. Antes eu ficava a dormir nos meus dias minguados, mas agora o meu sono é de pedra. Pássaro também disse. Antes eu não tinha esta afeição às bestas... (JORGE, 1982: 43).

Desse modo, a linguagem utilizada pelo povo do vilarejo é fator contribuinte para a alienação da aldeia. Este processo alienatório pode estar vinculado à consciência mítica das personagens, e esta, por sua vez, estabelece um vínculo com a consciência lingüística. Pelo que se pode notar, até mesmo as formações verbais de que se valem os aldeões para se comunicarem aparecem como entidades míticas, pois nestes discursos há a presença de mitos que permeiam toda a narrativa. Neste caso, a palavra se converte em uma espécie de potência em que radica todo o ser e todo acontecer. 


\section{CAPÍTULO IV}

\section{O CÍRCULO MÁGICO DE VILAMANINHOS}

A maneira pela qual a narrativa de Lídia Jorge é estruturada, evidenciando sob qual ótica a autora concebe o mundo, transmite ao leitor a impressão, no momento em que estabelece contato com o texto, de que está diante de um quebra-cabeça. Isso se dá pelo fato de que o discurso entrecortado das personagens sugere um mundo fissurado, com fragmentos que só se completam com a colaboração de outros fragmentos.

É possível notar que, na ficção, geralmente o raio de intenção se dirige à camada imaginária. Estão embutidos, por assim dizer, nas personagens, situações ou estados que induzem o leitor a viver, imaginariamente, os destinos e aventuras dos heróis. Este mundo imaginário é projetado pelo autor por meio da precisão da palavra, do ritmo e do estilo, dos aspectos esquemáticos especialmente selecionados, sobretudo no que se refere ao comportamento e à vida íntima das personagens.

Além disso, uma vez que a criação das personagens se apresenta como fruto do imaginário do romancista, as ações dessas mesmas personagens podem estar relacionadas com as experiências e vivências do autor. Acerca do episódio da cobra voadora, por exemplo, relata Lídia Jorge em uma entrevista a Gomes (1993: 151): 
Quando miúda, eu era muito imaginosa. Havia muita cobra naquele sítio, valhanos Deus, e eu vivia em pânico, com medo delas. E a idéia de que elas voavam e estavam por toda parte, ao mesmo tempo, apavorava-me e deliciava-me, porque sentia que era uma espécie de temor abismal, magnífico. Percebia também que havia muitas pessoas que faziam desenhos e bordavam o dragão, mas que não diziam dragão, diziam "cobra com asas, a cobra falada".

A história da cobra (que será analisada posteriormente) pode ser considerada como um transporte antropológico, genético, duma realidade vivida que, a priori, remete a um simbolismo vivido "sem o artifício literário" (Ibidem: 151), pois, diz a autora, "transportei tudo isso para o livro, mas de uma forma inocente, quer dizer, de uma forma sem mérito" (Ibidem: 152).

Isto posto, ainda é possível verificar que as experiências cotidianas do autor não somente contribuem para a construção da personagem, no que se refere às características físicas (no caso de Vilamaninhos as personagens vestem-se como "pessoas" que habitam na roça, um vestir próprio daqueles que vivem no Algarve, região onde nasceu a autora), mas também, e principalmente, contribuem para o desenvolvimento das suas atitudes e do comportamento das personagens, pelo costume de matarem cobras e por imaginarem que essas eram capazes de voar, como ocorre na Vilamaninhos.

O que é possível dizer acerca da personagem é que a sua natureza depende em parte da concepção que preside o romance e das intenções do romancista. Desse modo, originada ou não da observação, baseada mais - ou menos - na realidade, a "vida" da personagem depende da forma como se constitui a obra, da sua situação diante dos demais elementos que a compõem: outras personagens, ambiente, duração temporal, idéias. Seguindo esses moldes, Candido (2005: 75) postula que a caracterização das personagens vai “depender de uma escolha e distribuição conveniente de traços limitados e expressivos, que se entrosem na composição geral e sugiram a totalidade dum modo-de-ser, duma existência".

Em O Dia dos Prodígios a autora apresenta uma gama variada de personagens. Algumas desempenham papel central na trama, outras não passam de referência em meio a um diálogo ou são simplesmente tema de alguma conversa. Cria-se, ao longo da narrativa, um contexto social povoado de parentes e conhecidos, que garante uma aproximação, decorrente da circunstância de estarem geograficamente próximos uns dos outros e, ao mesmo tempo, um distanciamento em relação aos que vivem fora do vilarejo (mas também entre eles mesmos, muitas vezes). 
Esse isolamento em relação ao mundo exterior compõe o desenho imaginário da aldeia de Vilamaninhos como um círculo mágico, sugerindo, ali, uma ausência de historicidade, uma atemporalidade e um alheamento em relação ao mundo da cultura. É o que se pode depreender da descrição abaixo:

A saber. Vilamaninhos tem seis braços. Dois são feitos de casas ao longo da estrada que a atravessa, fita de alcatrão que se esburaca como roupa puída [...] uma nódoa de pedra a emergir do pez, depois uma, duas britas nítidas, apenas aglomeradas. [...] Vejam a porcaria da estrada. Os outros dois braços são o resto da antiga [...] E as outras duas pontas são o eixo do primitivo caminho. Feito de lajedos e pequenos degraus de pedra, socalcozitos de desnível do tamanho de um nada, onde os pés escapam e as ferraduras das bestas disferem faísca (JORGE, 1982: 71).

Trata-se, como se pode notar, de um espaço decadente, onde se encontram "casas em escombros [...] já da cor da terra. Como se uma nuvem de ocre e terracota líquida tivesse vindo das partes do mar abrir as pernas sobre a rua do empedrado" (Ibidem: 15). Um espaço caótico, um verdadeiro retrato da destruição (pela maneira como são descritas as casas e as ruas, como ambientes antigos, sujos e cobertos de monturo).

Tal condição de confinamento se expande, inclusive, ao comportamento das personagens, à forma como percebem o mundo e como analisam o que está ao seu redor; escapam, até certo ponto, José Maria e o Sargento Marinho, que, por habitarem fora do vilarejo, estão fora do espectro de personagens inseridas no "círculo mágico".

Idealmente, o percurso de vida de cada indivíduo é marcado pela busca de superação de si mesmo, através da interação com o outro, o que resulta, como já foi visto no capítulo anterior, no desenvolvimento não só desse indivíduo, mas também do seu povo. No entanto, esta superação não se processa entre os que vivem no vilarejo, pois estão fechados não somente em relação ao mundo, mas igualmente em relação a si mesmos. Pelo que se pode notar, trata-se de um estado de consciência que Hegel (2000: 140) chama de "consciência infeliz" e que causa no indivíduo um desligamento em relação a si mesmo.

O microcosmo de Vilamaninhos é o espaço de José Jorge Júnior e Esperança Tereza, José Pássaro e Branca Volante, que integram o grupo daqueles que vivem em matrimônio, transmitindo a vaga idéia de construção familiar, sem, no entanto, que, no seu interior, os 
contatos se realizem, pois, cada um, individualmente, vive num mundo que é exclusivamente seu. Entre os não casados, mas também pertencendo a este mundo fragmentado e atomizado, Manuel Gertrudes, ex-combatente que foi "soldado na primeira guerra deste século" (JORGE, 1982: 18); Jesuína Palha, aquela que se apresenta como porta-voz da comunidade de Vilamaninhos; Manuel Macário, o cantador lunático que se destaca como músico por excelência; Carminha Rosa e Carminha Parda (mãe e filha, respectivamente), que carregam em si um estigma, a primeira por ter-se envolvido com o padre da cidade e a segunda por ser fruto deste relacionamento.

A forma como se apresentam os camponeses, pelos costumes que prevalecem na comunidade e pela linguagem precária que utilizam, marcada pela oralidade, são alguns dos fortes indícios da relação entre a sociedade de Vilamaninhos e a sociedade medieval portuguesa. Por exemplo, o traje da personagem, por exemplo, evoca o vestuário simples da mulher do povo: "As camponesas vestiam-se com tecidos lisos, grosseiros, "usavam aventais e punham na cabeça coifas, capuzes e sombreiros" (MARQUES, 1971: 56), mas não deixavam de usar os adornos de ouro, prata e pedraria, que davam um esplendor e um brilho todo especial às roupagens.

Das personagens femininas, uma que representa com grande propriedade a mulher do povo - pela maneira como se expressa em sua linguagem regional e pela maneira como se veste, tal qual a figurante de uma grande ópera popular - é Jesuína Palha. Como as camponesas da Idade Média, ela se apresenta sempre de avental e com seu

lenço preto postado sobre a cabeça, apenas de pontas enlaçadas e não atadas, no alto, um pano ali. E tão imóvel quanto as pendurezas de oiro. Quietas e amarelas, resplandecem as feições do rosto com o brilho (JORGE, 1982: 137).

Jesuína Palha é identificada como uma espécie de líder da comunidade; incorpora os valores morais da sociedade de Vilamaninhos e, por isso, é considerada, por todos do vilarejo, uma mulher forte e valente (a única capaz de enfrentar a serpente voadora). Ocupa uma posição de poder diante dos habitantes da vila, pois, pela sua maneira de ser, impondo e humilhando, zela pela ordem e pelos bons costumes do lugar. As atitudes que assume, de uma mulher destemida, que tudo enfrenta, geralmente eram atribuídas a uma atitude masculina, quando "cospe no chão" (Ibidem: 144).

Jesuína, por esse comportamento valente, viril, líder e forte, desempenha um papel semelhante ao de um patriarca. De fato, na comunidade como um todo, os homens eram fracos e 
idosos, por isso incapacitados para governar os aldeões. Mas, por trás de toda essa autoridade, observa-se que Jesuína só consegue exercer essa função de líder quando se vale de um discurso que não é dela, fazendo a reprodução de um discurso masculino. Jesuína, inconscientemente, se conforma com isso quando ela incorpora as atitudes e a linguagem de um homem. Talvez seja essa a forma que Jesuína encontrou de libertação, mas esse discurso de que se vale não deixa de ser um discurso falso, que esconde, nas entrelinhas uma mulher que é tão limitada quanto os outros habitantes da vila.

Branca e Pássaro Volante também integram essa representação do universo patriarcal que marcou a cultura medieval portuguesa. Branca, por exemplo, é vítima desse sistema, pois se conforma com as regras que lhe são fixadas pelo marido, desenvolvendo primorosamente os papéis de esposa e mãe. Pássaro Volante impunha a sua autoridade e não permitia que ela afastasse os seus pensamentos dos afazeres do lar. Por isso, Pássaro ordena que Branca exerça a função de bordar só nas horas vagas, e ela obedecia

porque se alguma coisa faltasse fazer, e as escamas do dragão crescessem. Ah dedinhos, Branca estaria a esquecer-se dos seus deveres, e forçoso seria fazê-la lembrar. Cinco dedos estampados na pele. Não era para doer. Era mais a marca e lembrança (JORGE, 1982: 36).

Além de ser submetida ao poder masculino e desrespeitada em seus direitos de ser humano e livre, Branca ainda era associada a uma "mula", pois ambas, mula e mulher, são insolentes, loucas e também, perversamente, misteriosas e cínicas.

Como se não bastasse, o ato sexual entre Pássaro e Branca também é descrito como se ela fosse realmente uma mula:

Pássaro cavalga. Branca é um dorso macio de aragem pelada. Pássaro cavalga como se a montada tivesse partido à desfilada pelos caminhos, e ele cego por ver a terra tremer. E então o estremecimento sobre a montada da cama, veloz e horizontal, como se Pássaro se quisesse sacudir de si próprio, despejar o seu interior ai sobre (Ibidem: 48).

Pelo que se pode notar, Pássaro usa sua esposa para "se libertar das forças inúteis do seu corpo" (Ibidem: 128). Ele não só a considera como um objeto, mas também tem o intuito de 
privá-la de sua própria sexualidade. Branca, por sua vez, mostra-se como um anjo, pois além de servir ao marido e aos filhos com total dedicação, parece não ter sexualidade.

Branca não era submetida somente aos abusos que seu marido lhe infligia, mas também era subtraída de seu próprio corpo, de sua própria voz: "E eu mais do que submissa, acobardada. Caladinha" (JORGE, 1982: 88).

Para que Branca continuasse submissa e mantivesse a sua condição servil, Pássaro lhe impõe o bordado, para que ela pudesse se entreter nas horas vagas. Desse modo, "Branca Volante passaria as tardes com o espírito além das parreiras" (Ibidem: 35), sem ter tempo de afastar os seus pensamentos dos afazeres do lar. Mesmo assim, Pássaro temia o que se passava no espírito, pois era certo que isto ele "nunca poderia medir nem calcular" (Ibidem).

Sim, pois embora aparentemente dotada de pouca inteligência, em outras situações, parecia ter algum dom sobrenatural. De fato este dom existia, e, por meio de suas visões, Branca era capaz de prever o futuro das pessoas.

O dom que Branca possuía não era recente, pois, desde que tinha dezessete anos, “já se supunha com um alcance que ia mais além do presente até agarrar o futuro, com uma vidência feita de sobressaltos e chamada por palavras" (Ibidem: 60). Embora Pássaro dissesse a sua mulher que esta virtude era uma falsa fantasia, Branca identifica "quem vai chegando às portas da vizinhança mesmo sem os cães ladrarem. E se ladram eu ouço o regougar da garganta ainda antes de se ouvir o ladrido" (Ibidem: 64). Pelo que se observa, Branca é capaz de prever os acontecimentos da vida. Com isso, ela mergulha em uma dimensão temporal em que, "pouco a pouco deixou de haver presente" (Ibidem: 166), fazendo-a sentir "num ponto movediço de viscosidade" (Ibidem). Isto mostra que o próprio gesto de tecer e fiar pode significar, para Branca, entremear ou entrelaçar a realidade e a irrealidade.

Pássaro passou muito tempo sem acreditar no que Branca dizia, chamando-a de enteada do diabo e acusando-a de estar disposta a enlouquecê-lo. Certo dia, ela provou que era capaz de saber tanto de coisas do passado, falando do paradeiro de um canivete que Pássaro havia perdido quando tinha dez anos, "Vai junto do poial dos cântaros, levanta o terceiro ladrilho a contar da direita e lá o encontrarás" (Ibidem: 167), e também prevendo coisas futuras: "aqui à nossa porta, gente dos quatro ventos de Portugal virá fazer bicha de várias voltas. E ainda que tu não marques um preço, as esmolas vão ser tantas que terás para comer durante toda a vida” (Ibidem: 68). 
Outro membro da comunidade, José Jorge Júnior, 87 anos, assume em muitos momentos o papel de guardião da memória, cultuando o passado:

Alguma vez ouvira ela falar do alfabeto e das orações? Tinha esquecido tudo o que deveria estar guardado na casa da memória. Mas eu. Oh eu. José Jorge Júnior continuava a escrever. Com o indicador. Grandes letras invisíveis pelas paredes da casa. E reconhecendo de cor algumas parábolas do evangelho, recitava-as como se lesse, o missal aberto sobre um joelho, abanando a cabeça de lado a lado, gesto da antiga leitura (JORGE, 1982: 28).

Seu relato mistura também histórias da Bíblia:

No princípio do mundo. Quando os animais ferozes falavam, e deus se escondia a fazer negaças atrás das moitas, e se transformava na fúria dos elementos e no sangue dos animais. Tudo isso para estupidificar os incrédulos (Ibidem: 29);

e de seus antepassados:

E assim José Jorge cresceu, ajuntou-se e gerou a Manuel Jorge. E Manuel Jorge gerou a José Jorge. E José Jorge a Manuel Jorge que foi meu avô, e meu avô, Esperancinha, gerou a José Jorge que foi meu pai, que me gerou a mim, e me botou o seu nome, igual, mas pôs Júnior também, que significa menino, para não se confundirem as heranças (Ibidem: 31 ).

Esposa de José Jorge, Esperança Tereza - Esperancinha , maneira pela qual era chamada pelos habitantes de Vilamaninhos - é outra figura feminina voltada apenas para os afazeres domésticos, preocupando-se, principalmente, com os filhos. Isto pode ser observado por meio de uma tentativa (inútil) de diálogo que procura estabelecer com o marido: "os dois aqui de palestra sem se ouvirem. Falando, falando" (Ibidem: 33). Enquanto Esperança fala sobre os treze filhos que teve, relembrando os detalhes da infância de cada uma das crianças, José permanece em sua cadeira, numa posição de superioridade, falando sobre seus antepassados e em quão bravos eles foram.

Esta ação constante de reviver o passado, notada por meio de Esperança Tereza e seu marido, pode ser conseqüência da condição arcaica e isolada em que estavam na aldeia. 
Quanto à moral medieval, ela evidencia-se no tratamento discriminador dado às duas Carminhas, as quais portam em si a marca da culpa. Carminha Rosa e Carminha Parda são vítimas de um ostracismo e isolamento decorrentes da não aceitação dessas mulheres na sociedade, em conseqüência do envolvimento amoroso de Carminha Rosa com o padre da cidade:

O Padre Pardo dizia, quando me viu, que me adorava como à santinha Goreti. Mas depois, em vez de eu rezar de joelhos no confessionário, passou ele a rezar a meus pés na sacristia. Deixou de comer e dormir e começou a enganar-se no latim da missa (JORGE, 1982: 58).

O que mais havia seduzido Carminha Rosa era certa aura de santidade que o padre colocara nesta união secreta, chamando-a de "Santa Goreti, rainha da pureza e escrava do pecado alheio" (Ibidem: 96). Esta união rendeu um fruto, Carminha Parda, mas o padre, não assumindo suas responsabilidades como pai, "abalou de madrugada escarranchado sobre uma mula, levando entre as pernas um baú de paramentos e demais coisas santas" (Ibidem: 20) e desapareceu do vilarejo.

Carminha Rosa cometeu um duplo erro, como se não bastasse dar à luz a uma criança sem estar casada, ainda esta criança era filha de um padre. Desse modo, ao praticar este ato, a camponesa não considerou os valores impostos pela sociedade patriarcal, sociedade em que estava inserida, (que defende a idéia da mulher casar, dever obediência ao marido, ter filhos e dedicar a sua vida a cuidar do lar). Por conta disso, Carminha Rosa e sua filha sofrem por serem incriminadas perante toda a sociedade.

Jesuína Palha incumbe-se de culpar mãe e filha por tudo de ruim que acontece no vilarejo. Ainda assim, elas permanecem ali, vivendo humildemente e marcadas pelo estigma. Mas, como disse Carminha Rosa (Ibidem: 58), "a nossa pobreza é a dívida dos ultrajes feitos a deus. E agora o meu medo é outro. É que uma coisa visível ou invisível ainda possa vir a destruir este santo matrimônio. Da minha filha com a sua pessoa".

O que Carminha Rosa temia se concretizou. Carminha Parda, a filha, nasceu e cresceu isolada, pois toda a sociedade a condena por ser filha de um padre. Esta condição termina por marginalizá-la, a ponto de a comunidade chegar a supor que, extraordinariamente, em sua carne ficasse aparente a marca do pecado: 
o teu pai é incógnito, mas que nesta povoação ninguém ignora quem te gerou. Falam que no baptistério. Aí mesmo, sob as santas imagens e diante da cruz da via sacra. [...] Quando nasceste todos quiseram espreitar a tripa do umbigo e a rosinha das coxas, exactamente porque esperavam ser a mãe natureza pródiga de vinganças. Ou deus não seria justo (JORGE, 1982: 19).

Por carregarem este estigma (que se refere à paternidade de Carminha Parda), mãe e filha se entregam à purgação pela limpeza. Elas ficam a todo o tempo limpando a casa, e Carminha (a filha) parece pretender limpar de si a mancha daquele passado que ainda a faz sofrer e a coloca à margem da sociedade. A primeira cena de $O$ Dia dos Prodígios descreve Carminha Parda no afã de limpar, minuciosamente, a janela da casa que dava para a rua, pois era por meio desta janela que Carminha se comunicava com "o lado de lá do vidro, o rumor de gente falando" (Ibidem: 16). Veja-se o fragmento:

Carminha parecia fazer adeus, mas apenas lavava janelas. Um pano branco na mão. O braço adejando de encontro ao vidro. Alguidarzinho ajoujado de espuma cremosa. Um alguidar maior de pura água macia. Novelo de saias entre pernas. Cadeira de tabua ajaezada de nódoas, flores vermelhas. Os pés aí juntos no fundo côncavo. As pernas de leve penugem rasinha. Então Carminha empertigava-se de encontro à mancha renitente entre a unha e o vidro. Minúscula, fruto de mosca palhetando asas em tempo vazio, compondo um ovo de esterco redondo (Ibidem: 15).

Carminha Parda é uma moça meiga, pura:

Vê-se no espelho de vidro, Branca e lisa, sem resíduo de fogagem nem impingem. Sobrancelha rala, longe dos olhos escuros, e o escuro dos olhos sobre o azulado do branco, vidrado e transparente como verdadeiro vidro. Cabelo escorrido e pesado como uma cauda de cavalo. Preto, belo escorrido e pesado como uma cauda de cavalo. Preto, azulado e brilhante, reflexo de uma asa de corvo (Ibidem: 16).

É tímida e recatada, e isto pode ser observado pela maneira como a autora descreve a sexualidade desta personagem, relacionada ao mistério de um casulo: 
Apetece-lhe estender-se. Mostrar-se e sacudir o pólen da sua meninice. Abrir a blusa, desapertar os atilhos que lhe seguram os seios. Adejar as ancas e dizer aqui aqui. Mas isso dentro do seu casulo de pedra, telha, tijolo e uma janela de vidro (JORGE, 1982: 17).

Observa-se que há, nela, o contraste entre a sombra (casa escura, como se fosse uma névoa) e o brilho (a limpeza do vidro, transparência). Carminha anseia pela pureza e a liberdade, mas "Saindo para a rua a sombra do seu pai incógnito paralisa-a, gela-lhe o arquejar [...] Uma condenação" (Ibidem).

Pelo que se pode notar, há indícios de que ambas estejam condenadas a viver confinadas em suas casas, pois preferem o isolamento a terem que conviver com a discriminação de toda a comunidade de Vilamaninhos e, principalmente, com as ofensas e acusações de Jesuína Palha, fazendo-lhes perguntas que comprometem a moral e o bom comportamento das duas, "A quantos tu já deste a pinquinha? E a quantos tu hás-de a dar sem que nenhum te leve?” (Ibidem: 144).

Se o universo de Vilamaninhos apresenta, por um lado, seus veículos da opressão, há, por outro lado, a presença da elevação espiritual e estética da Idade Média. Quem a incorpora é Manuel Macário, um homem simples que, com o seu cantar trovadoresco e seu bandolim, gostava de divertir os camponeses com sua música, proporcionando a eles momentos de distração.

As pessoas do povo se divertiam, na Idade Média, em saraus onde se trovava e cantava. Os saraus eram conduzidos por trovadores; "eram em regra nobres que compunham o poema" (MARQUES, 1971: 196), e por jograis, artista de origem popular (vilão, ou seja, não pertencia à nobreza) que "cantavam e tocavam" (Ibidem). Mas, aproximadamente, no século XIV surgiram em Portugal os galiardos e estes "estavam a meio caminho entre os jograis e os trovadores, compondo eles próprios, recitando e cantando" (Ibidem, 197). Macário pode ser considerado um galiardo, pois, além de ser um artista popular, compõe as suas próprias melodias e poemas, canta e toca seu instrumento e o faz com naturalidade. Nos poemas compostos por Macário, os versos que ele canta apresentam um esquema rítmico, bem próximo do encontrado nos cancioneiros medievais:

Há sempre um ovo chocando.

Uma tristeza na gente [...]

Como se gente pensando, pusesse um ovo no quente. [...] 
Ah gente que só pensando.

Põem os ovos no quente (JORGE, 1982: 56).

E Macário diz, cantando de uma só vez:

Oh cobrinha do monturo.

Já descem aos cagadoiros.

Tem a vidinha no duto

quem porqui acha tesoiros.

Acha tesoiros e tesoiros (Ibidem: 112).

Ao documentar, cantando, o que se passa em Vilamaninhos, Macário mostra que há, em suas composições, traços da poesia lírica, pela maneira como expõe o seu discurso sempre ligado a um acompanhamento musical, no caso o seu bandolim.

$\mathrm{Na}$ Idade Média peninsular, a poesia lírica manifestou-se principalmente sob as formas de cantiga de amigo (em que o sujeito poético é uma donzela que exprime os seus sentimentos amorosos pelo amado, amigo); e de cantiga de amor, na qual o poeta exprime o seu amor por uma dama. A lírica não era composta apenas para acompanhar o canto, mas, sobretudo, ela se caracterizava pela atitude de expressão pessoal que o sujeito poético nela assumia. Era uma forma que o poeta tinha encontrado para se expressar, mas a pessoa a quem se referia não era nomeada. Macário também se vale da poesia para expor os seus pensamentos acerca da sociedade de Vilamaninhos e, também, para expressar os seus sentimentos amorosos em relação a Carminha Parda, mas, diferentemente dos cancioneiros medievais, não oculta a identidade de sua amada.

Macário não é o único representante da lírica trovadoresca que aparece no texto. Há outra figura definida apenas como o cantador que "apareceu, vindo das bandas da ponta extrema, nascente de Vilamaninhos" (Ibidem: 94) sendo descrito pelo narrador da seguinte maneira:

Trazia a boca muito aberta de cantar, e os olhos fechados como se fosse cego, tendo o dom de se desviar dos valados e das esquinas, apenas pelo faro, Balançava o bandolim de peito a peito e a mão tremia, fechada em punho sobre a boca da caixa. Como se lhe vibrasse uma verdadeira língua. Vinha sem abrigo nem chapéu, e as botas por atar. Vinha cantando. Apenas as palavras eram tão prolongadas que perdiam o corpo, e alguns sons tão represos na garganta que pareciam sussurros. Cantando (Ibidem). 
Não só o isolamento das personagens evoca a imagem do círculo. Também certas ações que algumas delas praticam, como o bordar, o lavar, o cantar, sugerem um mergulho numa espécie de tempo sem data ou sem hora, uma espécie de tempo interno, sem a linearidade do tempo cronológico.

Até o sono que se apodera de Manuel Macário está associado a essa circularidade: "Manuel Macário acordou de insolação lunar, e tendo tido conhecimento detalhado de tudo o que se passara nem matou a fome de catorze dias, três horas e trinta minutos" (JORGE, 1982: 38). É o que ocorre com a personagem em questão. Enquanto dorme é como se desaparecesse, morresse. Mas, após um tempo, reaparece e nesta aparição se comporta como se tivesse passado por um período de transformação.

Pode-se notar que a causa da insolação é atribuída à Lua, que, segundo Chevalier e Gheerbrant (2005: 561), simboliza os ritmos biológicos, pois é um

astro que cresce, decresce e desaparece, cuja vida depende da lei universal do vir-a-ser, do nascimento e da morte... a lua conhece uma história patética, semelhante à do homem... mas sua morte nunca é definitiva...

Do mesmo modo que ocorre com a Lua, Macário acorda com suas forças renovadas e, como se nada tivesse acontecido,

Afinou o bandolim com o ouvido sobre a madeira e o dedo zerpando as cordas, palheta dá-lhe que dá-lhe até achar oportuno. E não guardou o riso para o dia seguinte. Achava ele que vindo de outras esferas. Ah sem dúvida. Podia sorrir do que acontecia aos mortais que comiam e defecavam os trinta dias do mês (JORGE, 1982: 38).

A marcação do tempo acompanha as estações do ano, num movimento cíclico, implicando, também, um constante retorno. De acordo com Scholes (1977: 155) este movimento lembra o ritual da fertilidade das sociedades primitivas, em que

o tempo é encarado antes que tudo como uma maneira de dividir o ano individual em lugar de um acúmulo de anos sucessivos. O ano é dividido pelos equinócios e solstícios que marcam a evolução anual do sol através dos céus e 
servem como indicadores de variações sazonais na chuva, temperatura e outros fenômenos naturais associados ao ciclo da vida vegetativa.

De fato, a ação, em $O$ Dia dos Prodígios, ocorre no verão (na Europa, esta estação corresponde aos meses de junho, julho e agosto), quando Jesuína se empenha em matar a cobra. O outono é anunciado quando o narrador diz: "Finalmente alguém sentiu que setembro estava a chegar. [...] Sente-se um sopro de outono" (JORGE, 1982: 48). A primavera foi anunciada quando Maria Rebola, a dona do bar, abriu a porta da igreja "E deus fez vir o sol para aquecer o piolho da gente. As terras, vizinhos que se danem. Cresça o restolho. E isto é pela primavera" (Ibidem: 114).

Trata-se do tempo natural, em que o mundo é regido pelas forças da natureza. Os fenômenos naturais exercem, então, uma influência sobre as personagens:

O sargento. Teria sido anunciado pelas chuvas. E as chuvas anunciadas pelas moscas e pelo soldado. Mas as moscas, o soldado, a chuva, o vento e o sargento, o bem e o mal. Segundo a Palha. Tudo foi anunciado pela cobra (Ibidem: 124).

Esse caráter cíclico do tempo acompanha a ambientação mítica e é tratado por Massaud Moisés (1985) por tempo metafísico ou mítico, estando ligado a um tempo ontológico no qual o importante é refletir sobre o ser. Trata-se, ainda de acordo com Moisés (Ibidem: 109), do "tempo de todos, não de um indivíduo, tempo da Humanidade, quando era só corpo fundido às coisas do Mundo, tempo reversível em circularidade perene, tempo primordial, [...] tempo sacro, tempo eterno, sem começo nem fim”.

A ação, nessa narrativa mítica, maneira pela qual pode ser caracterizada a obra de Lídia Jorge, passa-se, desse modo, um passado remoto. E este é o que dá um sentido geral à vida dos que habitam em Vilamaninhos, pois, de certa forma, estão alheios ao mundo, perdidos num ponto do passado, afastando-se, cada vez mais, do presente histórico.

Já Nunes afirma (1995: 66) que não há um tempo mítico, pois “o mito, história sagrada do cosmos, do homem, das coisas e da cultura, abole a sucessão temporal". Por outras palavras, a ausência desta sucessão temporal sugere um tempo único, e, no que se refere à obra de Lídia Jorge, independentemente do que ocorre com os habitantes do vilarejo e das ações que eles narram, o que se conta será sempre produzido neste tempo único. A esse respeito, o modo de narrar também contribui para evocar a circularidade. 
Em qualquer obra narrativa, o narrador é figura importante, inclusive para a caracterização das personagens. Por isso, vale a pena verificar como esta instância narrativa, que vai conduzindo o leitor por um mundo que parece estar se criando à sua frente, se desenvolve na narrativa em questão. O narrador pode apresentar-se como um elemento não envolvido na história, portanto, uma verdadeira câmera, ou como uma personagem envolvida direta ou indiretamente com os acontecimentos narrados.

A narração em primeira ou terceira pessoa, a descrição minuciosa ou sintética dos traços, os discursos direto, indireto ou indireto livre, os diálogos e os monólogos são técnicas escolhidas e combinadas pelo escritor a fim de possibilitar a existência de suas criaturas fictícias, as personagens.

Em O Dia dos Prodígios o narrador em terceira pessoa situa-se como uma espécie de câmera cinematográfica privilegiada, que vai construindo, por meio de pistas fornecidas pela narração, pelas descrições e pelo diálogo, o perfil das personagens que transitam pela intriga e simbolizam o mundo que ele quer retratar. A câmera, como advertiu Brait (1993: 57), "finge registros e constrói as personagens". Este narrador controla o desenvolvimento da estória, penetrando-a, numa relação dialógica que convoca outra voz e com ela começa a dialogar:

Então é que Macário diz as palavras e toca num bandolim de oito cordas. [...] Também o cantoneiro de quadril quadrado e ombro largo e espadaúdo, veste de cinzento de cotim, e pousa ao lado o chapéu de lata e os óculos de rede. [...] Um assobio enche e chupa a bochecha. Sobe, atravessa o ar e cai como um jato no silêncio da igreja amarelecida da tarde. Mas não se ouve um fluido som sequer. Os cães fugidos do largo, como que espantados duma ameaça, agora ausente. Manuel Gertrudes. Esse também espera. [...] Coisas cavadas por torrentes. E os dedos? Os dedos duros como raízes, mas movem-se (JORGE, 1982: 139).

O romance narrado em terceira pessoa, como diz Ricoeur (1995: 148), é o que mais se estende na inspeção do interior das mentes, pois conta "os pensamentos, os sentimentos e as palavras de um outro fictício”. Em outras palavras, há um deslizar do exterior para o interior que envolve profundamente o narrador na situação narrada o que implica uma passagem do discurso indireto para o discurso indireto livre. Este tipo de discurso permite uma mescla entre a voz do narrador (em terceira pessoa) e da personagem (em primeira pessoa), expondo os pensamentos da personagem sem que o narrador perca seu poder de mediador. Com isso, surgem, em meio à 
narrativa, diálogos indiretos da personagem como se esses diálogos complementassem o discurso do narrador. Isto pode ser observado no trecho a seguir em que se mesclam a fala de Pássaro Volante, do narrador em terceira pessoa e do cantoneiro:

Bravo eu. Senhor de feiras. Pernaiças afeitas às montadas. E Branca meia hora depois veria o ladrilho levantado. Haveria de carrer as migalhas e juntaria os triângulos, casando-os pelas pontas. Depois Pássaro sairia para a rua, alontando as passadas, enquanto fosse fresco da manhã, e o cantoneiro. Em cima do camião, Branca. Em cima dele, você montaria o seu negócio. Senhora dona. Sim, não vai ser um negócio, mas uma caridade. Sim, é isso. José Maria, cantoneiro. De terra em terra. Eu havia de parar onde alguém fizesse o sinal de querer consultar a sua virtude (JORGE, 1982: 169).

O envolvimento, que se intensifica por meio da visão microscópica do narrador e da voz do presente expressa pela personagem, pode causar a sensação de um distanciamento progressivo do foco inicial:

Carminha deixou-se estar. Para além das casas, a estrada. Para além da estrada, o mato. Para além do mato os figueirais, e as outras terras, e as outras ainda. Para além de todas as terras, o mar. Para além do mar o sul, e no caminho do sul mais extremo, o bojo da terra, e para além do bojo da terra. No fundo dos escuros, das noites e dos dias. Muito para além de tudo isso (Ibidem: 96).

Em outros momentos, pode causar uma sensação de aproximação:

No centro da casa fica a mulher bordando. No centro da mulher bordando. Plantada no colo. Fica a colcha de linho cru, adamascado. No centro da colcha uma figura de escamas bordadas (Ibidem: 35).

Este "movimento" de distanciamento e aproximação que a narrativa sugere, alude à absorção, pelo romance, das técnicas cinematográficas da "montagem, cortes bruscos, simultaneidade" (LEITE, 1993: 74), pois são vários os ângulos a partir dos quais o romance é narrado. O narrador, ao se valer destas técnicas, simula um registro contínuo que ora focaliza a personagem, bem de perto, em momentos precisos, no caso Branca Volante tecendo seu bordado, 
ora afasta-se progressivamente da personagem, evidenciando uma espécie de ampliação acelerada do ângulo de visão.

Pelo que se pode notar, o ângulo de visão do narrador em relação à personagem permite observar o que se passa dentro do mundo psíquico deste "ser de papel", o que remete a uma técnica narrativa que se apresenta como monólogo interior. Trata-se, nas palavras de Leite (Ibidem: 67) "do aprofundamento nos processos mentais das personagens, mas feito de maneira indireta, por uma espécie de narrador onisciente que, ao mesmo tempo, os expõe e os analisa". Esta sondagem interna acaba desencadeando um verdadeiro fluxo ininterrupto de pensamentos, "fluxo de consciência" (Ibidem: 68).

Por meio desta expressão direta dos estados mentais, o autor retrata fielmente os pensamentos e a imaginação das personagens, mas de maneira desarticulada. Esta desarticulação apresenta-se na narrativa por meio das falas e ações, realidades e desejos, anseios e reminiscências que se misturam na narrativa num jorro descontínuo, numa sintaxe caótica, em que a sequência lógica se perde e o pensamento das personagens simplesmente flui diretamente do inconsciente. Trata-se, ainda segundo Leite (Ibidem), de um "desenrolar ininterrupto do pensamento", que resulta na expressão de uma associação livre de idéias.

Nota-se o fluxo de consciência em O Dia dos Prodígios no trecho a seguir, em que o narrador expõe a sua voz em terceira pessoa, mas há uma atitude confessional no discurso que remete à primeira pessoa, falando consigo mesma ou acerca de si mesma:

Para Carminha, antes um forasteiro. Fazendo erguer a pardalada, um forasteiro que chegasse e se pusesse de conversar. E ela de lhe dar trela com um baque no coração descompassado de encontro à grade das costelas. A cavalo num cavalo ou num motor. Carminha ouvi falar de ti (JORGE, 1982: 19).

Quando o fluxo de consciência emerge na narrativa, tem-se a impressão de que o autor deixou a personagem entregue a si mesma, às suas divagações. Neste caso, esta associação livre de idéias, de feitio incoerente, que pode ser apresentada pela personagem no fluxo de consciência, também é mostrada na obra de Lídia Jorge por meio de um dos discursos de Carminha Parda: "E eu sempre esquiva. Agora vou ficar com tudo isto para oferecer a ninguém. Uma inutilidade insignificante. Um desperdício do corpo. Oh deus" (Ibidem: 99). Seria o que o narrador chama de "pensamentos destes por outras palavras interiores" (Ibidem: 20). 
O fluxo de consciência, evidenciando a atividade mental das personagens, revela, na obra de Lídia Jorge, por meio das personagens Esperancinha Tereza e José Jorge Junior, uma intensidade dos sentimentos de ambos, a ponto de ficarem sempre de palestra sem se ouvirem. Ele vive das histórias de seus antepassados, enquanto ela vive da lembrança dos filhos: " $\mathrm{E}$ eu doze vezes di à luz, José. Tu te alembras?” (JORGE, 1982: 30). São os próprios pensamentos e as lembranças, de ambos, que se manifestam. Isto causa, neste caso, um distanciamento do momento presente, pois são pensamentos que vão ao encontro de um tempo distante, reproduzido somente na memória dessas personagens.

Este modo de narrar convoca também o leitor e o considera partícipe da narrativa. No esquema tradicional da prosa, tal como no Realismo do século XIX, por exemplo, exigia-se um distanciamento em relação aos fatos narrados e, muitas vezes, as relações que se estabelecem entre autor e leitor não requerem uma participação ativa deste leitor, para que se estabeleça a interpretação, pois ele, geralmente, exerce a função de mero observador dos fatos.

No entanto, na prosa contemporânea, ao menos em muitos casos, é importante que o leitor se torne um co-partícipe, uma espécie de co-autor, pois, para além da interpretação dos fatos, a sua imaginação também se ativa e organiza os dados que lhe são fornecidos. Em $O$ Dia dos Prodígios, essa mesma característica de convocação aparece quando as personagens são chamadas a participar de uma conversa que lembra as reuniões ao redor das fogueiras em tempos imemoriais. É o que ocorre, por exemplo, no discurso do tio José Jorge: "Chega-te aqui Esperancinha, senta-se nessa cadeira [...] para ouvires o que ainda me lembro sobre a gente dos meus passados" (Ibidem: 29).

Nota-se ainda que o narrador instaura, pela maneira como constrói a narrativa, um vozeiro que se estabelece concomitantemente entre as personagens. Isto pode ser observado logo no início do texto, numa breve introdução feita pelo narrador: "E falemos todos ao mesmo tempo [...] Para que ficasse bem claro o desentendimento" (Ibidem: 13). Este narrar implica, necessariamente, como postulou Gomes (1993: 73) um "distanciamento do narrador" e a voz desse narrador fragmenta-se em "vozes também responsáveis pela articulação da narrativa". Tem-se, porém, a impressão de que a história surge diretamente das impressões e da mente das personagens. 
Em outros momentos, há, paralelamente ao discurso do narrador, um ondear de vozes que afirma um discurso próprio. Este vozeiro aparece em forma de comentários breves e estes comentários apresentam-se a margem do discurso principal:

Manuel Gertrudes disse. Se Macário estivesse acordado, as quadras que não cantaria. E Matilde disse. A cobra? E Manuel Gertrudes disse. Sobre que haverá de ser. E João Martins disse. Se ele visse Carminha a passar, ou pelo menos a sua voz, já as quadras seriam outras. E José Maria, o cantoneiro, disse. Antes as de amor. Só essas me enchem os ouvidos (JORGE, 1982: 37).

Em síntese, há uma sutil subversão do comportamento tradicional do narrador, pois como observou Gomes (1993: 114) o narrador "recusa o seu estatuto de divindade e assume a sua humanidade". Coloca-se, portanto, no mesmo plano que as personagens e não passa de uma voz entre vozes, pois o que importa é o tom da fala e não o grau de sua onisciência.

Pelo que se nota, como afirma Leite (1993: 72), "substitui-se o narrador por uma voz diretamente envolvida no que narra, narrando por apresentação direta e atual, presente e sensível, pela própria desarticulação da linguagem, o movimento miúdo das suas emoções e o fluxo dos seus pensamentos". Com isso, anula-se a distância entre o narrado e a narração, o que pode resultar na supremacia da voz que fala sobre a voz que conta.

O estudo do ponto de vista em O Dia dos Prodígios permite observar, seguindo as idéias de Pouillon (1974: 100), que "a condição primordial é participar da intriga, mergulhando em um mundo que o narrador não nos descreve, mas no qual nos lança". Tem-se a impressão de que o narrador não tem como objetivo principal transmitir ao leitor um conhecimento, mas sim fazê-lo “desfrutar", com as personagens, de tudo que se passa na narrativa.

No caso desta obra, em que a ação ocorre num tempo e num espaço remotos, este conhecimento que o narrador possui, de acordo com Benjamim (1993: 201), é retirado de sua própria experiência e incorpora as coisas narradas à experiência de seus ouvintes, pois muitas personagens confessam este gosto pelo falar e ouvir, "Vinha eu para te dizer o que acaba de acontecer a todos os habitantes" (JORGE, 1982: 18); "Os relatos dos circundantes eram simultâneos, entrecortados de afegações e de ais" (Idem: 29).

Ainda de acordo com Walter Benjamin (1993: 210) é possível notar que a relação do ouvinte com o narrador visa a "conservar o que foi narrado", pois "a memória é a mais épica de 
todas as faculdades". Sendo assim, cabe ao narrador de histórias a função de reavivar a memória coletiva, e sabe-se que, quando uma história é repetida, ela se presentifica no tempo.

Nota-se, assim, a relação que se estabelece entre o foco narrativo e a temporalidade que se constitui na obra, pois o narrador, por meio da fala das personagens e por meio de sua própria fala, se constitui como o porta-voz do tempo.

Outro fator importante a concorrer para a sugestão da circularidade temporal advém da associação, na narrativa, entre o discurso da prosa e o da poesia, esta última resultando, fundamentalmente, de um "ver" radicado na intuição. Este tipo de apreensão do real e sua conseqüente expressão em imagens são peculiares às sociedades primitivas e revelam o estado primitivo, mítico daquelas comunidades.

Esta forma de visão intuitiva, que resulta numa apreensão analógica do real, é, como já se disse, própria das sociedades arcaicas, às quais parece identificar-se a aldeia de Vilamaninhos. Tal forma de apreensão do real e de integração/interação com eles se dão por meio de leituras míticas e comportamentos ritualísticos em relação a esse mesmo real, como se pode ver no episódio da serpente voadora, que será objeto do próximo capítulo. 


\section{CAPÍTULO V}

\section{OS GESTOS RITUALÍSTICOS EM O DIA DOS PRODÍGIOS}

Pelo comportamento das personagens em $O$ Dia dos Prodígios (no que se refere ao discurso que utilizam, às ações que praticam, à sua concepção de mundo) é possível depreender que se inserem em um estado de consciência muito inferior (em relação às pessoas que vivem fora do vilarejo), arcaico. Como se viu, vivem em um espaço e um tempo marcados pela estagnação, o que acarreta uma dificuldade de evolução, de saída desse estágio primitivo para iniciar um processo de evolução.

Esse estado rudimentar da consciência está refletido, inclusive, na linguagem utilizada pelos vilamaninhenses e na falta de clareza na comunicação com o outro, especialmente com quem está distante do seu universo social. A resposta de Maria Rebola (sobrinha de José Jorge Junior) aos soldados que falavam sobre liberdade ilustra esse fosso entre os dois mundos: "Cuidado, não falem à gente por parábolas. Que há dezoito anos que não temos cura, mas conhecemo-las todas de cor e não nos deram nada" (JORGE, 1982: 160).

Mas entre os próprios habitantes ocorre uma dificuldade de interação semelhante, como ilustra a relação entre Esperança Teresa e o marido, que, embora falem um com o outro, não 
conversam. Ao que parece, só existe, como afirma Bakhtin (2004), um “eu-para-mim”, aquele que só se constitui na relação consigo mesmo e não na relação com o outro.

Outro aspecto revelador desse nível de consciência é a linguagem que utilizam, marcada pela oralidade e, além disso, num estágio de evolução que remete ao medieval: "Di-lhe bem umas trinta canadas sobre a espinha e a cabeça. Di ou não di? [...] Toda a gente se tinha já alevantado da cama" (JORGE, 1982: 23).

As atitudes e o discurso de certas personagens, como José Jorge e Jesuína Palha, por exemplo, indiciam a presença, no imaginário da população da aldeia, imagens arquetípicas que ora remetem às origens, ora remetem ao anúncio dos fins, construindo uma noção esmagadora de que entre princípio e fim não parece haver, ou ter havido, nada. A própria construção temporal, mostrando a ausência de uma seqüência cadenciada, com constantes avanços e recuos, também remete o leitor a um tempo em que passado, presente e futuro parecem fazer parte da mesma tela. Neste cenário, os acontecimentos são lavrados indistintamente, como se nada estivesse sujeito a evolução: o leitor parece estar in illo tempore, no tempo do mito.

Importante esclarecer que a conceituação do mito não tem aqui a conotação usual de fábula, lenda, invenção, ficção, mas a acepção que lhe atribuíam e ainda atribuem as sociedades arcaicas (denominadas civilizações primitivas) em que o mito é o relato de um acontecimento ocorrido no tempo primordial, mediante a intervenção de entes sobrenaturais. Por outras palavras, mito refere-se ao relato de uma história verdadeira, ocorrida nos tempos dos princípios, por exemplo, os mitos gregos Édipo, Orfeu e Penélope (que aparecem em O Dia dos Prodígios, que chegaram até a comunidade pela tradição oral).

Apresentado como uma representação coletiva, o mito relata uma explicação do mundo e da realidade humana por meio da palavra revelada, o dito. Desse modo, o mito pode exprimir-se no nível da linguagem, pois, antes de fixar-se como narrativa, este pode representar uma palavra, uma imagem, um gesto, que circunscreve o acontecimento no coração do homem. De acordo com o ponto de vista de Max Muller, citado por Cassirer (1972), o mito constitui-se como algo condicionado e mediado pela linguagem: na realidade, é o resultado de uma deficiência lingüística originária, de uma debilidade inerente à linguagem.

O mito é, portanto, uma característica essencial da linguagem, e nesta reconhece-se a forma externa do pensamento. Isso quer dizer que linguagem e pensamento estão intimamente relacionados, pois, em todas as esferas possíveis da atividade espiritual, a linguagem exerce total 
poder sobre o pensamento. De fato, a linguagem, ou seja, a palavra, é o que realmente desvenda ao homem aquele mundo que está mais próximo dele. Somente ela tem o poder de fazer o homem seguir sua vida em comunidade e, por meio dessa convivência social, ele assume de forma determinada o seu próprio eu, sua subjetividade. Mas é necessário que o indivíduo se aproprie do inconsciente coletivo, fazendo uma relação com o consciente, seguindo os modelos primitivos, beneficiando-se de todas as forças e energias que jorram das origens, para que possa desenvolver o seu pensamento mítico.

Quanto aos símbolos religiosos que integram o imaginário das personagens e alimentam a vida cotidiana e as vivências pessoais do povo do vilarejo, de acordo com Guimarães (s/d: p.7), essa ocorrência se deve ao sentido religioso que se presentifica em determinados mitos que narram as façanhas dos heróis civilizadores. O culto a estes heróis oferece certa analogia com o culto dos santos, no Cristianismo. Desse modo, aquilo que era conhecido como religião, dogmas e ritos, foi desdobrado, posteriormente, em mitos.

A tendência ao religioso adquiriu significativa importância nos trabalhos de Carl Gustav Jung. Para ele, esta atitude do espírito humano está fundada na "experiência do numinoso", que se define como o influxo de uma consciência invisível que produz uma alteração especial na consciência. Essa transformação ocorrida na consciência resulta na "consideração e observação cuidadosas de certos fatores dinâmicos concebidos como 'potências': espíritos, demônios, deuses, leis, idéias, ideais..." (JUNG, 1995: 10).

O estágio de desenvolvimento da consciência das personagens também pode ajudar na compreensão da existência da magia e do sobrenatural, que explicam certos acontecimentos ou que constituem a aura que envolve o real. Essa magia, que envolve, em grau maior ou menor, toda a população de Vilamaninhos, transparece no episódio da cobra voadora, tão central na intriga quanto o episódio da Revolução dos Cravos, que ocorre simultaneamente. Trata-se de uma serpente comum que, ao ser morta com um pedaço de cana pela personagem Jesuína Palha, alça vôo e desaparece no ar.

Este episódio constitui o foco da trama O Dia dos Prodígios, e a serpente prodigiosa (capaz até de voar), produto da imaginação do povo do vilarejo, reveste-se de sobrenatural. De fato, a cobra é responsável por introduzir o "mistério no quadro da vida real" (TODOROV, 2004: 32), pois, antes do aparecimento dessa serpente, nada de interessante acontecia e a população da vila "ia ficando um ovo emurchecido. Que fede, gorado, e não gera” (JORGE, 1982: 21). 
A serpente surge no vilarejo como um "fantasma palpável”, mas escorrega por entre os dedos de Jesuína Palha, como se deslizasse através do tempo. Esse súbito desaparecimento causa um certo pavor no povo do vilarejo, "A gente agora vai andando, e vê a bicha. Pranta-se o pé e acha-se a bicha. Toca-se a cara e sente-se a bicha. E eu? Não vou comer durante três dias com esta visão" (JORGE, 1982: 27). Esse temor é compreensível, desde que se leve em consideração a descrição que Chevalier e Gheerbrant (2005: 815) fazem da cobra: "Grande Serpente Invisível, causal e atemporal, senhora do princípio vital e de todas as forças da natureza”. Esse é, sem dúvida, um acontecimento extraordinário que muda completamente a vida daquele pequeno e muito peculiar grupo de pessoas.

O episódio da cobra causa, também, nos habitantes da vila uma sensação de que estão em perigo, como se anunciasse a eventual irrupção, a qualquer instante, de algo ameaçador. É essa expectativa que faz criar um ambiente ficcional com as características do fantástico:

Carminha Rosa acordou várias vezes durante a noite. Era um leve bater de postigo. Depois uma telha tinindo na outra. Um conhecimento imperfeito, mas autêntico, de que alguma coisa andava às apalpadelas pela casa. Sem ser gente. Nem vento, nem chuva (JORGE, 1982: 95).

A descrição e execução da cobra por Jesuína Palha, como já se disse, faz referência a uma espécie de ritual. Isso se nota pela expressão dos vilamaninhenses no momento em que Jesuína executa a serpente, completamente atônitos e sem mover sequer um músculo. Enquanto Jesuína, mostrando-se valente, deixa aflorar toda a sua força batendo com um pedaço de cana sobre a serpente, "Ninguém dava um ai nem um jasus. E aqui estes vizinhos sentiam ânsias e punham a mão na boca do bucho" (Ibidem: 23). Os vilamaninhenses estavam estatelados diante daquele acontecimento, verdadeiramente hipnotizados diante da atitude daquela mulher dotada de coragem, a única no vilarejo capaz de enfrentar o réptil. Essa hipnose, causada pelo estado de perplexidade em que os moradores se encontravam, remete, com bastante intensidade, à realização de um ritual.

Os gestos e as atitudes de Jesuína Palha fazem notar que a personagem parece desprenderse, por alguns instantes, do mundo real, aquele que Scholes (1977: 93) chamou de "mundo verdadeiro e histórico", para tornar-se participante de um evento mítico, pois este "tinha lugar fora do tempo cronológico comum" (Ibidem). Isso ocorre pelo fato de os habitantes do vilarejo 
estarem situados em um tempo mítico, ou seja, aquele não relacionado a história. Mas, ainda seguindo as idéias de Scholes (Idem), os conceitos de história e realidade estavam intimamente ligados e, por isso, o intuito não era destruir o mundo empírico, mas sim estabelecer uma sincronia entre realidade mítica e empírica

Jesuína Palha, orgulhosa de seu feito e certa de que tinha executado a cobra, resolve levantar o animal acima de sua cabeça para mostrar aos vilamaninhenses a "bicha de lado e de ventre" (JORGE, 1982: 25). De repente "a cobra fez duas roscas à volta da cana, saiu dela, e voando por cima dos nossos chapéus e dos nossos lenços, desapareceu no ar. Voou no ar" (Ibidem) transformando-se num dragão voador com "asas de escamas, espelhadas e furta-cores" (Ibidem). Aquele animal, até então uma simples cobra, adquiria as características de um 'dragão alado', que passa, então, a povoar os sonhos coletivos.

A imagem da serpente, considerada um arquétipo fundamental ligada às fontes da imaginação e da vida, funde-se agora no dragão: "saíram-lhe duas asas dos flanquinhos, como uma fantasia de circo. Só que aquilo era tudo vardade o que a gente víamos. Com os nossos próprios olhos" (Ibidem: 25). Cria-se uma atmosfera de suspense em torno desse episódio da cobra, e esta atmosfera, como afirma Todorov (2004), era o que havia de mais importante, pois o critério definitivo de autenticidade do fantástico não era a estrutura da intriga, mas a criação de uma impressão específica em função da intensidade emocional que esse elemento fantástico provoca.

Este episódio traz vários índices que permitem caracterizá-lo como fantástico. A narrativa de modalidade fantástica oferece ao leitor a possibilidade de pôr em causa o universo descrito, desafiando as regras clássicas da verossimilhança em que se alicerça a construção da narrativa "tradicional". Parece constituir-se como um desafio aos limites impostos para a leitura do real, procurando ligar-se a um mundo cuja existência está para além dos limites do possível. Surge ao olhar do leitor como uma narrativa que rompe, permanentemente, com os limites do universo considerado como possível.

De acordo com a crítica, o fantástico constitui um acontecimento que é produto da imaginação e não pode ser explicado pelas leis comuns que regem a natureza. Trata-se de uma ilusão dos sentidos. Por isso, no interior dos textos fantásticos há presença de elementos inverossímeis, imaginários, distantes da realidade dos homens. Sendo assim, como postulou 
Todorov (2004), o fantástico é a hesitação experimentada por um ser que só conhece as leis naturais, em face de um acontecimento aparentemente sobrenatural.

Na literatura fantástica, esta hesitação, ainda de acordo com Todorov, é a oscilação entre o real e o ficcional. Em $O$ Dia dos Prodígios observa-se que emerge, na narrativa, a dúvida quanto à veracidade do que está acontecendo; o que cerca os habitantes do vilarejo é mesmo a realidade (e então a cobra realmente voou) ou tudo não passou, simplesmente, de uma ilusão que toma a forma de um sonho?

Desse modo, na literatura fantástica, fica sempre preservada a possibilidade exterior e formal de uma explicação simples para os fenômenos, mas, ao mesmo tempo, essa explicação é completamente privada de probabilidade interna. Nesse caso, tem-se, na obra em questão, um comprometimento não com o visível, com o aparente, e nem com o documental dos fatos, mas com aquilo que constitui mesmo a essência dos fatos: o imaginário de todo um povo.

Algumas personagens acreditam, veementemente, que a cobra teria voado; já outras, como José Jorge Júnior, dizem que "um bicho réptil voar de vísceras de fora, só deveria ter acontecido nos tempos bíblicos, muito e muito antigos. No princípio do mundo" (JORGE, 1982: 29). Esperança Tereza, esposa de Jorge, pensava da mesma forma e preferia "Mil vezes antes mergulhar nas cogitações da sua vida passada. Sempre à mão da lembrança. Longa e dulcificada" (Ibidem) do que dar importância à cobra. Essa ambigüidade se mantém até o fim da narrativa, realidade ou sonho? De acordo com Todorov (2004: 58) é característico do fantástico ocupar o tempo dessa incerteza. Sendo assim, o próprio fato de o evento permanecer sem explicação, nãoracionalizado, sugere a existência do sobrenatural.

A simbologia da cobra como uma manifestação mágica pode também remeter ao conto maravilhoso. Na criação literária, de acordo com Chiampi (1980: 49), o conto maravilhoso permite a "intervenção de seres sobrenaturais, divinos ou lendários (deuses, deusas, anjos, demônios, gênios, fadas) na ação narrativa ou dramática. É identificado, muitas vezes, com o efeito que provocam tais intervenções no ouvinte ou leitor (admiração, surpresa, espanto, arrebatamento)". É possível acrescentar, com base no ponto de vista de Coelho (1991: 14) que o maravilhoso se constitui como uma narrativa "sem presença de fadas; via de regra se desenvolve no cotidiano mágico (animais falantes, objetos mágicos, gênios, duendes etc.)”. O pau utilizado por Jesuína Palha para matar a cobra poderia ser considerado um desses objetos mágicos, pois talvez ele pudesse ter transformado a cobra num dragão alado. 
Observa-se que o momento da transformação da cobra em um dragão alado pode remeter a uma experiência desse tipo, pois se trata de um acontecimento inusitado, que desperta, nos habitantes daquele vilarejo, reverência e uma mescla de temor e respeito por algo que se mostra superior a eles (divindades e forças sobrenaturais) e ao seu entendimento. Portanto, a atitude descrita por Jesuína Palha, "Quando vi a víbora cegui os olhos. Alavanti a saia, brandi a cana, uma, duas, três, sete e vinte vezes sobre a cabeça da bicha" (JORGE, 1982: 22), pode ser compreendida a partir da perspectiva junguiana acerca do numinoso, cuja presença provoca reações que fogem do controle, fazendo irromper no indivíduo forças coletivas que independem de sua vontade.

Pelo episódio da cobra-dragão, é possível observar que há, na aldeia de Vilamaninhos, representando uma parcela do povo português, um desejo de esperar por algo que seja, concomitantemente, repelente e magnífico, para salvá-los e tirá-los daquele estado de estagnação em que estavam. No entanto, não sabem quando isso ocorrerá, mas, mesmo assim, aguardam, como o gosto da pura espera inútil. Esta espera permeia toda a narrativa e está atrelada à mentalidade e ao comportamento da maioria das personagens. que anseiam pelo retorno desse ser mítico (a cobra), sabe-se lá de onde, ou, pelo menos, sonhavam com alguma explicação para esse fenômeno.

Esta espera pode remeter ao Sebastianismo, movimento messiânico centrado na figura do rei D. Sebastião, de Portugal, desaparecido na Batalha de Alcácer-Quibir, ocorrida a 4 de agosto de 1578 , e por cujo retorno a população anseia, no sentido de dar continuidade ao período de prosperidade do Renascimento.

A espera do salvador, de acordo com Megiani (2003: 20) "é um mito conhecido em praticamente todas as culturas e mitologias, sejam elas primitivas ou civilizadas”. Sendo assim, é possível notar este componente não somente no imaginário do povo português, mas também no imaginário de toda a humanidade. A história de um povo que espera pela chegada do seu salvador, seja ele um herói, seja um líder espiritual, é um dos fenômenos sociais mais antigos e constantes na história da humanidade, pois pode ser encontrado entre as populações mais distantes. O mito retorna na essência, assumindo, entretanto, as cores e nuanças da cultura em que ele se manifesta.

O Sebastianismo talvez seja uma manifestação muito mais complexa do que a simples espera pela chegada de um salvador para Portugal. Desse modo, como pensa Megiani (Ibidem: 
32), pode ser tomado como um grande bloco de tradições culturais trazidas por diferentes povos e etnias e isto ultrapassa as fronteiras de Portugal e da própria Península Ibérica. Desses povos, três forças culturais conseguiram estabelecer-se: cristã, judaica e muçulmana. As três trouxeram para o Ocidente uma forte manifestação da experiência messiânica, bem como uma literatura voltada para o anúncio da chegada do fim dos tempos, também conhecida pela denominação de escatologia.

No que se refere ao povo de Vilamaninhos, observa-se que o messianismo aparece como um dado recorrente no imaginário do povo do vilarejo, pois, como já foi dito, se caracterizam por um pensar e sentir míticos, que mantêm suas raízes em tempos remotos e muito distantes dos acontecimentos que marcaram Portugal na década de 70 .

Este pensamento mítico-religioso presente na obra também pode transparecer, na obra, pela expectativa do escatológico, ou, em outras palavras, do fim dos tempos. Desse modo, o tempo da espera, em $O$ Dia dos Prodígios, também pode ligar-se ao fim dos tempos, que é anunciado por uma tríade que apresenta sinais apocalípticos. O primeiro sinal remete ao grande mistério do desaparecimento da cobra morta, que criou asas de escama e voou, desaparecendo como por encanto; o segundo está relacionado ao espanto de Pássaro ao ver a mula sorrir por mais de três vezes: “com as bestas, um homem dá aveia e elas comem, mas se lhe der só palha acabam por comê-la [...] voltando a dar cevada e aveia elas riem logo a um homem. De orelha estendida" (JORGE, 1982: 107); o terceiro manisfesta-se quando José Jorge Júnior sente-se perseguido por males indignos, que seriam as formigas, bichos pequenos, figuras quase imóveis, tão presentes e incômodas que trepavam no corpo e penetravam na boca.

Estes sinais de fins dos tempos, na obra de Lídia Jorge, podem ser um prenúncio de que o homem está sendo preparado, mediante privações, suplícios e sofrimentos, para o advento definitivo do Reino da Salvação. Isto pode ser visto no discurso de Branca:

Foi o sinal do céu mais evidente de que tudo o que possuis te pode escapulir das mãos imprevistamente. Através das bestas, teu primeiro bem. [...] As bestas não só enlouquecem como cada vez apresentam mais moléstias. Conhecidas e desconhecidas. Para além de que se reproduzem cada vez menos e por isso custam cada vez mais. Ah cego de ti sobre os sinais dos tempos e a linguagem das bestas (Ibidem: 106). 
Tal leitura, por parte da população, é reveladora do nível de consciência dos habitantes da aldeia, que, ao invés de agirem como construtores do próprio destino, só sabem esperar pelo salvador ou pelo fim dos tempos. Sendo assim:

...nada avança sobre Vilamaninhos. Nem o arreeiro, nem um pedinte de portas que possa trazer, inventar notícias. Sente-se o ar fechado. As palavras da telefonia de Pássaro têm um ruído de distância, música e discursos posteriores aos factos (JORGE, 1982: 139).

Nota-se que essa sociedade encontra-se num estágio de "consciência infeliz", que não avança e nem progride, ao contrário, congela-se.

O mito sebástico está enraizado na cultura portuguesa. Em O Dia dos Prodígios, a espera pela salvação chega a ser um traço da identidade cultural deste povo, pois é algo que está inserido no íntimo dos lusitanos, e essa identidade é extraída da própria história deles.

Por outro lado, a cobra pode representar, simbolicamente, um outro tipo de libertação, pois, ao voar (mesmo que este vôo seja fruto do imaginário daquele povo), consegue se deslocar para outro espaço fora da vila. E os camponeses, juntamente com a serpente, deveriam também deslocar-se para outro espaço.

Este deslocar-se não implica um deslocamento físico, sair do vilarejo, mas sim, nas palavras de Hegel (2000), libertar o espírito do estado de consciência arcaica em que se encontra. Alçar vôo livre e encontrar-se consigo mesmo no absoluto proporcionaria às personagens maior autonomia e que, conseqüentemente, poderia romper o estado de aprisionamento no qual se encontram. Mas não é o que ocorre, continuam inseridas em um universo que é muito restrito e particular, sem nenhuma perspectiva de mudança e progresso.

Ou ainda pode constituir um gesto simbólico (e ritualístico), que possibilita a evolução dos integrantes da comunidade por meio da vitória sobre as forças subterrâneas do mal, forças estas alegorizadas pela imagem tripartida da cobra/ serpente-alada/ dragão. Esta vitória garante a reconstrução de um universo novo sobre o caos. Ao atribuir à cobra essa condição de réptil voador, o grupo lhe confere um sentido mágico, pois se trata de um elemento sobrenatural que aparece integrado à realidade. Cria-se, pelos vilamaninhenses, uma nova postura diante do real, um modo diferente de encarar aquela realidade insossa e rodeada de pessoas apáticas. E esse modo estranho, complexo, muitas vezes esotérico, evoca, magicamente, o início de uma nova era, a fundação de um novo mundo, que substituiria o antigo ambiente de marasmo. Pensando-se em 
termos de "realismo mágico", parecem procurar "captar a banalidade da vida diária, removendo-a de seu contexto e fundindo-lhe uma aura mágica". (CHIAMPI, 1980: 22)

Como já se disse, o desconhecido provoca, geralmente, um certo temor. Por isso, "Pressentimos que a cobra não era só cobra e tivemos medo..." (JORGE, 1982: 24). O medo desse animal rastejante desperta nos camponeses o desejo obsessivo de destruí-lo, mas, pelo que parece, temem que esse réptil, pelas forças sobrenaturais que adquire, termine por dominá-los. À simbologia da cobra pode-se agregar um aspecto negativo quando Jesuína diz: "Este tempo me traz pressentimentos ruins" (Ibidem: 68). Por outro lado, nas palavras de Manuel Gertrudes, uma outra personagem da obra, a serpente assume seu aspecto positivo, "Eu tenho um grande pressentimento. Que uma nova maravilha vai acontecer sobre o redondo do mundo. Uma gente nova vai povoar a terra. Purificados" (Ibidem: 86).

Em contrapartida, Carminha Parda e Branca Volante são personagens que, inconscientemente, se encontram no caminho da superação deste estágio da "consciência infeliz".

Para Carminha, primeiramente, pelo fato de impor a sua vontade para a mãe, quando diz que não quer mais casar com o Sargento; posteriormente, quando decide que não vai mais esperar por um pretendente que venha de fora, pois encontra a solução para seu caso amoroso dentro de Vilamaninhos, casando-se com Macário.

Para Branca a opressão parece ser superada quando se liberta da sujeição do marido com sua privilegiada vidência e como ela mesma diz: "eu própria fiz mudança, porque nunca consegui dizer tantas palavras junto de ti. Ou seja da noite, ou da revolução, ou de mim mesma" (Ibidem: 148). Ao que parece, esta personagem liberta-se da tirania do marido, e ele, indiretamente, contribui para isso, pois, quando ordenou que ela bordasse, com o intuito de prender os pensamentos de Branca exclusivamente aos assuntos domésticos, na realidade, a liberava para seu espaço de liberdade interior.

O gesto de bordar (o criar com as próprias mãos) pode remeter ao gesto ancestral da própria criação do mundo, e a previsão do futuro (o criar com o próprio espírito) pode, em última instância, estar na base do próprio processo criador ficcional. Desse modo, pode-se dizer que há uma aliança entre o bordar e o prever o futuro, a qual caracteriza, nesta personagem, a libertação. Ao longo da narrativa, dos que habitavam na vila Branca era, talvez, a única que criava algo com suas próprias mãos, ou seja, a única que tinha plantado a semente da esperança e que tinha a visão de um futuro, mesmo que fosse o dos outros. 
Se este ato de Branca simboliza sua elevação espiritual, a evolução do seu nível de consciência, em Carminha Parda o ato que simboliza processo semelhante é o de limpar as janelas. Na obra, ambos se caracterizam por serem vagarosos e atentos e, como já se disse no capítulo anterior, propiciam um movimento de imersão no tempo ontológico, que conduz o indivíduo ao encontro de si mesmo. Além disso, envolvem, ainda, uma ligação com o ato de "ver" para além da realidade imediata, uma vez que, para Branca, o dragão que ela borda parece querer saltar do tecido e ganhar vida própria e, para Carminha, a limpeza liga-se à condição de ver para além do seu espaço de enclausuramento e libertar-se da condição em que vivia.

O drama de Carminha Parda, inclusive, está indiretamente associado ao mito de Édipo, de quem ela já ouvira falar:

Carminha tinha ouvido falar de um homem do princípio do mundo, desenterrando os olhos com os próprios dedos, [...] Coberto de sangue, a andar de porta em porta pedindo pão pelo amor de deus. E isso tudo não por culpas presentes, mas tão passadas que já nem eram suas. Um severo animal quase mudo, dizendo charadas a quem entrasse na cidade (JORGE, 1982: 38).

Édipo, Filho de Laio, rei de Tebas, e de Jocasta, por causa da prioridade em um desfiladeiro estreito, mata Laio, ignorando que este era seu pai. A caminho de Tebas encontra a Esfinge, um monstro, meio leão meio mulher, que devorava aqueles que não conseguiam responder aos seus enigmas. Ao decifrar o enigma desse monstro que devastava a região, Édipo o mata e, por conta disso, é aclamado rei. Como recompensa recebe Jocasta como esposa, viúva de Laio, sem saber que ela é sua própria mãe. Quando descobre esse feito, Édipo, arranca seus próprios olhos e Jocasta se mata.

O mito de Édipo, segundo algumas interpretações, “é o símbolo do homem que oscila entre o nervosismo e a banalização. Ele compensa sua inferioridade (a alma ferida) por meio da ativa busca de uma superioridade dominadora" (CHEVALIER; GHEERBRANT, 2005: 356). Desse modo, pode simbolizar na obra de Lídia Jorge o sentimento de inferioridade que a personagem Carminha, a filha, possui em relação aos outros habitantes do vilarejo, por ser filha de um pai incógnito. Por outro lado, também pode estar relacionado à culpa que lhe é imposta pelo vilarejo (e que, até certo ponto, ela assume, libertando-se finalmente, ao que aparece, no momento em que decide não se casar com o Sargento, após ter presenciado seu gesto de 
crueldade para com os cães). Neste caso, o que ocorre com Carminha é o inverso do que ocorre no mito: enquanto Édipo arranca seus olhos para não ver a verdade, a capacidade de visão (interior) da personagem Carminha surge quando ela, liberta de sua culpa, assume, por assim dizer, sua própria verdade: a de que não quer submeter-se à tirania do grupo (do mesmo modo que Branca recusa submeter-se à tirania do marido).

Outra personagem cuja ação se volta para a elevação espiritual é Macário, o poeta e músico, figura associada a Orfeu: Macário tem o seu bandolim, ao passo que Orfeu tem a lira ou cítara. Ambos utilizam seus instrumentos de cordas, símbolos da inspiração poética e musical, para despertar o amor de suas musas, Eurídice (a de Orfeu) e Carminha Parda (a de Macário).

Diz a lenda que Eurídice, ao caminhar pelas margens do rio, é atacada por Aristeu. Desesperada e tentando livrar-se do atacante, pisa sobre uma serpente escondida na vegetação e morre por ser picada. Assim como a musa do mito, Carminha Parda também tem algo a ver com a serpente. Orfeu, julgando que deveria procurá-la, mesmo entre os mortos, toma sua lira e desce ao inferno. Com seu canto, o herói valente inebriou os deuses e os monstros que guardavam a porta da morada dos mortos. Quando Orfeu tange seu instrumento, toda a natureza se extasia. Com Macário não é diferente, sua canção agrada tanto que ninguém quer abandonar o largo apesar da noite, como se fizesse uma experiência de júbilo mal rematado. Macário sente isso profundamente "começou a compor uma canção de amor muito triste para que os vilamaninhenses pudessem chorar publicamente por uma coisa, dizendo que era por outra" (JORGE, 1982: 158).

Comovidos com a paixão de Orfeu e encantados com sua música, Hades e Perséfone entregam-lhe Eurídice, mas lhe impuseram a condição de só olhar para a sua amada quando ambos já tivessem deixado o inferno. Orfeu concordou e começou a caminhar de volta ao mundo dos vivos, seguido, a certa distância, pela amada. Exatamente nessa passagem há um diálogo evidente entre os textos, pois Lídia Jorge apresenta o caminho que Macário e Carminha percorreram para se encontrarem:

Macário surgiu de entre as penedias dum quintal. Por onde amadureciam erva [...] É possível que não venha e eu tenha de compor novas até a convencer. [...] Nesse momento Carminha apareceu caminhado às arrecuas, como se receasse que as próprias cigarras das amendoeiras a vissem passar. [...] Aqui não porque é muito perto de casa [...] E puseram-se a andar. [...] Mas Carminha olhou em 
redor, e ao ver a erva seca alta e fofa como um lençol de cama, disse. Aqui não, ainda é perto de mais de casa [...] Retornaram o caminho, [...] E já perto do rio, Macário. Macário caiu de joelhos às abas duma alfarrobeira submersa em folharasca. [...] Aqui. Disse. Aqui também não, por causa dos pedregulhos. E ele disse. Vamos. Então subiram (JORGE, 1982: 164).

Era um caminho, assim como na lenda, também cheio de obstáculos, mas Macário ia abrindo os ramos de uma figueira para que sua amada passasse "E ela curvou-se tanto quanto necessário para passar entre as abas sem aí deixar um fiapo de cabelo negro, penetrou na sombra, sentou-se sobre os torrões de terra e disse. Só se ouvem pássaros” (Ibidem: 165). Com muito esforço, Macário encontra-se com sua Eurídice portuguesa. Ao passo que Orfeu, cometendo um deslize ao achar que tinha superado todos os obstáculos, olha para trás e perde sua musa para sempre nos abismos infernais.

Este 'inferno' destacado no mito pode fazer referência, na obra de Lídia Jorge, à situação em que Carminha se encontra na narrativa, pois, pelo que se pode notar ao longo de todo o texto, Carminha é vitima de muitas decepções. Primeiro, por ser fruto de uma relação proibida e pecaminosa, depois, por ter sofrido com a morte de seu noivo, Manuel Amado e, finalmente, por ter-se comprometido com o Sargento Marinho, um homem de péssima índole. Significativamente, são duas figuras masculinas ligadas ao poder dominante: a Igreja e o Exército.

Manuel Macário é diferente do pretendente anterior; é um ser sensível, refugiado no paraíso de sua infância e voltado sobre si mesmo; está sempre em busca de valores superiores, que exigem desprendimento das vaidades humanas. Sendo assim, não é por acaso que Macário não se envolve nos conflitos diários do povo do vilarejo, afinal está em sintonia com a lua e com sua inspiração musical. Isto permite que ele faça parte de outra esfera, do sonho, do inconsciente e dos valores noturnos, e que possa simbolizar, aqui, o Poeta, prestando sua vassalagem a Carminha.

Branca e Carminha - duas personagens femininas que se emancipam em relação aos demais membros do seu grupo. Por meio dessas figuras femininas emblemáticas, observa-se que o romance talvez, possa sugerir que a mudança em relação à condição feminina de submissão e obediência seja capaz de revolucionar a sociedade lusitana. 
No que concerne à realidade portuguesa, surgem, para questionar a prática da submissão feminina, Maria Isabel Barreno, Maria Teresa Horta e Maria Velho da Costa - as Três Marias autoras de Novas Cartas Portuguesas, que ousaram transgredir, utilizando a dignidade da palavra escrita, denunciando a forma como era constituída a sociedade feminina durante o regime salazarista, criticando a educação e a formação das mulheres.

O objetivo das Três Marias ao publicarem as Novas Cartas Portuguesas era tirar as mulheres da obscuridade em que as haviam mergulhado os demandos da ditadura, mantendo-as reféns do medo e da repressão. Dessa maneira, essa obra foi um libelo contra a legislação, a moral e os costumes vigentes na sociedade portuguesa no período de Salazar.

Mas os chefes reagiram imediatamente: o livro foi apreendido, as autoras foram acusadas de divulgação de pornografia, sujeitas a uma campanha de difamação por parte das camadas bem pensantes e processadas judicialmente. Desse modo, a obra só conseguiu passar pela censura e ser publicada após o 25 de abril de 1974.

As Novas Cartas Portuguesas se inscrevem como um símbolo político da libertação feminina no século XX, no contexto histórico-político do apagar das luzes do período salazarista. Direcionada para a vida, esta obra se consuma também como uma proclamação de liberdade na arte da escrita feminina, pois é após a sua emergência que muitas vozes portuguesas femininas vêm-se fazendo ouvir nessa busca pelos labirintos da condição humana. Lídia Jorge está inserida neste contexto.

Toda essa transformação proporcionada pelas Três Marias ao escreverem a explosiva obra que marca historicamente a presença do erotismo na literatura feminina portuguesa, não é suficiente para alterar o comportamento alienado das mulheres. Isso ocorre pelo fato de que ainda vigoram os modelos profundamente arcaicos, que remontam aos primórdios do sistema patriarcal e que têm a ver com a organização das relações em que o homem comanda tudo e a mulher a tudo obedece. Não com a mesma intensidade, mas os processos de mutação em Portugal foram muito mitigados e, por esse motivo, esses paradigmas ainda se encontram atuantes.

Sendo assim, cria-se nas personagens, pelos motivos que já foram apontados, uma mentalidade que se acomoda diante dos fatos, como se observa por meio de Jesuína Palha e aqueles que seguem seus demandos; Esperança Tereza; José Jorge Junior, que vive enraizado no passado. Talvez Branca Volante e Carminha Parda, além de Macário, estejam em um nível de 
consciência mais evoluído em relação aos outros habitantes do vilarejo e simbolizem a esperança depositada na Mulher e no Poeta. 


\section{CONCLUSÃO}

A evolução sócio-econômica e cultural de Portugal processou-se de modo desigual na cidade e no campo. Ainda no período renascentista das grandes descobertas - período de maior prosperidade do país - a mentalidade medieval se manteve viva, e assim permaneceu ao longo do tempo nas comunidades agrárias do país. Essa situação talvez seja parcialmente responsável pela adesão do povo ao regime salazarista. De fato, as ditaduras ajustam-se sob medida aos grupos sociais conservadores, para os quais o progresso e o desenvolvimento seriam alcançados por meio da figura messiânica de um salvador.

As quase cinco décadas de administração salazarista provocaram danos talvez dificilmente reversíveis à cultura portuguesa: contribuiu para disseminar e enraizar preconceitos e estereótipos, utilizou as ferramentas da educação como veículos de manipulação da ideologia dominante, gerando, no meio português, a estagnação e o conformismo.

Assim, num país como Portugal, cujas origens remontam ao Catolicismo e ao Feudalismo medievais, e cuja sociedade evolui essencialmente pautada nesses valores da tradição, compreende-se que Lídia Jorge tenha construído Vilamaninhos e seus moradores como representação figurativa da estrutura e da mentalidade tradicionais do povo lusitano, particularmente nas regiões agrárias, como o Algarve, onde nasceu a autora.

O movimento da Revolução dos Cravos, deflagrado em Lisboa a 25 de abril de 1974, teve, como uma de suas principais orientações, concentrar esforços na área educacional, no 
sentido de prover as populações mais atrasadas do país com uma educação de maior qualidade, que efetivamente as libertasse das opressões do regime ditatorial.

A dinâmica de emancipação da consciência, que ocorre por meio da interação do eu com o outro e gera a transformação do sujeito em agente da sua própria história (e, por extensão, da de sua coletividade), tornou-se um dos temas caros a Hegel e ocupou o centro das suas preocupações, em função das condições precárias dos integrantes das populações mais carentes durante o regime absolutista.

Hegel viveu em um contexto em que eram necessárias, valorizadas e esperadas as ações sociais; tratava-se do contexto intermediário entre o século XVIII iluminista e o século XIX romântico, que valorizou a responsabilidade do indivíduo e do seu grupo e o efeito de suas ações nas mudanças históricas.

Os escritores da geração de 80, identificando-se com o pensamento daquela geração de pensadores, atuaram na mesma linha: procuraram fazer da ficção um espaço de revisão da História. No caso de O Dia dos Prodígios, a ambientação da ação no cenário de Vilamaninhos, aldeia que concentra em si os principais elementos representativos da mentalidade arcaica, com seus mitos, rituais e sua linguagem marcada pela oralidade, representa ficcionalmente, como se viu, o estado de consciência mítica em que vivem os aldeões portugueses, ilustrando o atraso dessas populações, mesmo numa época de grandes progressos como foi o século XX.

Ainda quanto ao estágio arcaico dessas populações, é interessante ressaltar o tratamento bifronte que Lídia dá ao mito: no caso das personagens mais ligadas à terra, como é o caso de Jesuína Palha, o mito desempenha o papel de atualizador de uma realidade ancestral; o episódio da luta entre Jesuína e a cobra voadora é uma variação do mito cosmogônico, que atualiza a ação da fundação do mundo.

Por outro lado, a relação entre as personagens Carminha, Branca e Macário e o mito são invertidas, ou seja, a relação se dá ao contrário do que se deu no tempo original, o que também aponta para a atitude revisionista, paródica, em relação ao mito, tal como é peculiar à literatura pós-moderna. Retomando o que já foi dito a esse respeito, os mitos de Penélope, Édipo e Orfeu estão ligados ao ato de ver: no caso de Penélope, tecer/ver envolve a espera de um acontecimento futuro, o retorno de Ulisses; no caso de Édipo não ver (cegar-se) envolve a recusa da própria culpa (na verdade, na sua trágica história, essa personagem foi, acima de tudo, um títere nas mãos do destino); quanto a Orfeu, foi punido por voltar-se para ver Eurídice. Em O Dia dos Prodígios, 
ver, como se viu, está associado ao agir consciente, ao tornar-se sujeito do próprio destino, à lucidez da consciência. Todas essas conotações são rebaixadoras do mito, porque o colocam no contexto prosaico e com sentido diverso do sentido original.

Nesse sentido, estas três personagens contêm, em seu bojo, o núcleo da esperança revolucionária: a mudança de atitude em relação ao outro e, por extensão, em relação ao espaço social. Na obra, esse anseio de mudança demanda uma ação efetiva do grupo, sem que existam líderes e liderados, mas que ambos - líderes e liderados - se encaminhem na direção de um objetivo comum: o da construção do novo mundo - o da Revolução.

Se Carminha Parda e Branca Volante são figuras femininas emblemáticas da emancipação da pessoa humana, a obra sugere que elas seguem as marcas deixadas pelas três Marias e pelas Novas Cartas Portuguesas, em que as mulheres passam a ser ouvidas no país, mesmo que isso não lhes tenha sido permitido. Neste caso, as mulheres de $O$ Dia dos Prodígios transgridem o parâmetro dos mitos, ou de personagens santas, como Santa Maria Goreti; nesse sentido, o que elas seguem é a luz da própria consciência, como fizeram as escritoras femininas, que, no período que antecedeu de alguns anos a Revolução dos Cravos, tiveram a ousadia de se fazerem ouvir apesar de tudo.

Isso parece indicar não a mera crítica à, nem a apologia das posturas femininas, mas sim um convite a que as mulheres, especialmente as portuguesas, não se sujeitem à dominação e possam vir a se tornar capazes de construir sua própria história e a de seu país. 


\section{OBRAS DE LÍDIA JORGE}

O Dia dos Prodígios. 3. ed. Lisboa: Publicações Europa-América, 1982.

O Cais das Merendas. 3. ed. Lisboa: Publicações Europa-América, s. d.

Notícia da Cidade Silvestre. 2. ed. Lisboa: Publicações Europa-América, 1984.

A Costa dos Murmúrios. Lisboa: Publicações Dom Quixote, 1988.

A Última Dona. Lisboa: Publicações Dom Quixote, 1992.

A Instrumentalista. Lisboa: Publicações Dom Quixote, 1992.

O Jardim sem Limites. Lisboa: Publicações Dom Quixote, 1995.

A Maçon. Lisboa: Sociedade Portuguesa de Autores / Publicações Dom Quixote,1997.

Marido e outros contos. Lisboa: Publicações Dom Quixote, 1997.

O Vale da Paixão. Lisboa: Publicações Dom Quixote, 1998.

O Vento Assobiando nas Gruas. Lisboa: Publicações Dom Quixote, 2003.

O Belo Adormecido. Lisboa: Publicações Dom Quixote, 2004. 


\section{OBRAS SOBRE A LÍDIA JORGE}

EMINESCU, Roxana. Novas Coordenadas do Romance Português. Lisboa: Instituto de Cultura e língua Portuguesa, 1983, pp. 58-59, 78, 115-119.

Português do Livro, 1984.

. Pequeno Roteiro de História da Literatura Portuguesa. Lisboa: Instituto

GOMES, Álvaro Cardoso. A Literatura Portuguesa em Perspectiva: simbolismo e modernismo. 4. ed. São Paulo: Atlas, 1994.

Contemporâneo. São Paulo: Editora da Universidade de São Paulo, 1993.

Lidia Jorge: in other words, por outras palavras. Portuguese Literatury \& Cultural Studies. University of Massachusetts Dartmouth, 1999.

MEDINA, Cremilda. Viagem a Literatura Portuguesa Contemporânea. Rio, Nórdica, 1983.

NUNES, Élida Jacomini. A Oralidade em O Dia dos Prodígios, de Lídia Jorge. Tese (Doutorado em Letras) - Departamento de Letras da Faculdade de Filosofia, Letras e Ciências Humanas da Universidade de São Paulo. São Paulo: USP, 2006.

ZILI, Therezinha. Ruínas da Memória: uma arqueologia da narrativa O Jardim sem limites. São Paulo: Hucitec, 2004. 


\section{REFERÊNCIAS BIBLIOGRÁFICAS}

ARRIAGA, Lopes. Mocidade Portuguesa: breve história de uma organização salazarista. Lisboa: Terra Livre, 1976.

BAKHTIN, Mikhail. A Cultura Popular na Idade Média e no Renascimento: o contexto de François Rebelais. Trad. Yara Frateschi Vieira. 5. ed. São Paulo: Editora Hucitec, 2002.

. Marxismo e Filosofia da Linguagem. Trad. Michel Lahud e Yara Frateschi

Vieira. 11. ed. São Paulo: Editora Hucitec, 2004.

BARROS, Diana Luz Pessoa de. Dialogismo, Polifonia e Enunciação. In: BARROS, Diana Luz Pessoa de; FIORIN, José Luiz. (Orgs.). Dialogismo, Polifonia, Intertextualidade: Em torno de Bakhtin. São Paulo: Editora da Universidade de São Paulo, 1999.

BENJAMIN, Walter. Magia e Técnica, Arte e Política. Obras Escolhidas, vol. I. Trad. Sérgio Paulo Rouanet. 6. ed. São Paulo: Editora Brasiliense, 1993.

BRAIT, Beth. A Personagem. 5. ed. São Paulo: Editora Ática, 1993.

CAMÕES, Luís de. Os Lusíadas. São Paulo: Círculo do Livro, s.d.

CANDIDO, Antônio. A Personagem no Romance. In:____ A Personagem de Ficção. vol. 1 11. ed. São Paulo: Perspectiva, 2005.

CASSIRER, Ernst. Linguagem e Mito. Trad. J. Guinsburg e Miriam Schnaiderman. São Paulo: Perspectiva, 1972.

CHEVAlIER, Jean; GHEERBRANT, Alain. Dicionário de Símbolos. 19. ed. Rio de Janeiro: José Olimpio, 2005.

CHIAMPI, Irlemar. O Realismo Maravilhoso. São Paulo: Perspectiva, 1980.

COELHO, Nelly Novais. O Conto de Fadas. 2. ed. São Paulo: Editora Àtica, 1991.

FÁVERO, Leonor Lopes. Paródia e Dialogismo. In: BARROS, Diana Luz Pessoa de; FIORIN, José Luiz (Orgs.) Dialogismo, Polifonia, Intertextualidade: Em torno de Bakhtin. São Paulo: Editora da Universidade de São Paulo, 1999.

FERNANDES, Helio. Retrato da Ditadura Salazarista. In: Salazar Visto do Brasil: antologia de textos de autores brasileiros e portugueses. São Paulo: Editora Felman-Rego, 1962.

GOMES, Álvaro Cardoso. A Literatura Portuguesa em Perspectiva: simbolismo e modernismo. 4. ed. São Paulo: Atlas, 1994. 
GUIMARÃES, Ruth (s/d) Dicionário da Mitologia Grega. São Paulo: Cultrix.

HALL, Stuart. A identidade cultural na Pós-Modernidade. 5. ed. Rio de Janeiro: DP\&A editora, 2001.

HEGEL, G. W. F. Fenomenologia do Espírito: Parte I. Trad. Paulo Meneses. 5. ed. Petrópolis: Vozes, 2000.

. Lecciones sobre la Filosofía de la Historia Universal. Trad. José Gaos. 2. ed. Madrid: Alianza Editorial, 1982.

. Phénomenologie del'Esprit: Presentation, Traductiorn et notes par Gwendoline Jarczyk et Pierre-Jean Labarrière. Paris: Éditions Gallimard, 1993.

HUTCHEON, Linda. Poética do pós-modernismo: história, teoria, ficção. Trad. Ricardo Cruz. Rio de Janeiro: Imago Ed., 1991.

HYPPOLITE, Jean. Gênesis y Estructura de la Fenomenologia del Espíritu de Hegel. Barcelona: Ediciones Península, 1991.

JUNG, Carl Gustav. Psicologia e Religião. Trad. Mateus Ramalho Rocha. Petrópolis: Vozes, 1995.

LEITE, Ligia Chiappini Moraes. O Foco Narrativo. São Paulo: Ática, 1993.

LOURENÇO, Eduardo. A Europa Desencantada: para uma mitologia européia. Lisboa: Visão, 1994.

MARCUSCHI, Luís Antônio. Análise da Conversação. São Paulo: Ática, 1986.

MARQUES, A. H. de Oliveira. A Sociedade Medieval Portuguesa: aspectos de vida quotidiana. Lisboa: Sá da Costa Editora, 1971.

MEGIANI, Ana Paula Torres. O Jovem Rei Encantado: expectativas do messianismo régio em Portugal, séculos XIII a XVI. São Paulo: Hucitec, 2003.

MOISÉS, Massaud. A Criação Literária: prosa. São Paulo: Cultrix, 1985.

NUNES, Benedito. O Tempo na Narrativa. 2. ed. São Paulo: Ática, 1995.

POUILLON, Jean. O Tempo na Romance. Trad. Heloysa de Lima Dantas. São Paulo: Cultrix, 1974.

RICOEUR, Paul. Tempo e Narrativa. Tomo II Campinas: Papirus, 1995. 
ROCCO, Maria Thereza Fraga. A oralidade na escrita de Platão. In URBANO, Hudinilson (Org.). et al. Dino Pretti e seus temas: oralidade, literatura, mídia e ensino. São Paulo: Cortez Editora, 2001, p. 279-285.

SANT'ANNA, Affonso Romano de. Paródia, Paráfrase \& Cia. São Paulo: Editora Ática, 2000.

SANTANNA, Jaime dos Reis. Literatura e Ideologia. São Paulo: Editora Novo Século Literário, 2003.

SANTOS, Jair Ferreira dos. O que é pós-moderno. 5. ed. São Paulo: Editora Brasiliense, 1988.

SCHOLES, Robert; KELlOG, R.. Trad. Gert Meyer. A Natureza da narrativa. São Paulo: McGraw-Hill do Brasil, 1977.

SECCO, Lincoln. A Revolução dos Cravos e a crise do império colonial português: economias, espaços e tomadas de consciência. São Paulo: Alameda, 2004.

TODOROV, Tzvetan. Introdução à Literatura Fantástica. São Paulo: Perspectiva, 2004.

TORGAL, Luís Reis. O Estado Novo, Salazarismo, Fascismo e Europa. In: TENGARRINHA, José. (Org.) História de Portugal. 2. ed. São Paulo: Edusc, 2001. 


\section{BIBLIOGRAFIA}

ALMEIDA, Maria Aparecida Fonseca de. Novas Cartas Portuguesas: o exercício da linguagem e o exercício da paixão. Dissertação de Mestrado - Departamento de Letras da Faculdade de Filosofia, Letras e Ciências Humanas da Universidade de São Paulo. São Paulo: USP, 1983.

AMORIN, Marília. O Pesquisador e seu outro: Bakhtin nas Ciências Humanas. São Paulo: Musa Editora, 2001.

BAKHTIN, Mikhail. Questões de Literatura e de Estética: a teoria do romance. Trad. Aurora Fornoni Bernardini. 2. ed. São Paulo: Hucitec, 1990. . Estética da Criação Verbal. São Paulo: Martins Fonte, 2003.

BARTHES, Roland. Mitologias. Trad. Rita Buorgermino e Pedro de Souza. 7. ed. São Paulo: Editora Bertrand Brasil- DIFEL, 1987. . O Prazer do Texto. Trad. J. Guinsburg. 4. ed. São Paulo: Perspectiva, 2006.

BEDASEE, Raimunda. Identidade e Alteridade na Literatura Feminina. In: IV Congresso Abralic. Anais - Literatura e Diferença. Sao Paulo, 31 de julho, 1, 2 e 3 de agosto, 1994.

BERMAN, Marshall. Tudo que é sólido desmancha no ar: a aventura da modernidade. Trad. Carlos Felipe Moisés, Ana Maria L. Ioriatti. São Paulo: Cia. das Letras, 1986.

BRAIT, Beth. (Org.) Bakhtin, Dialogismo e Construção do sentido. 2. ed. rev. Campinas: Editora da UNICAMP, 2005.

. Ironia em perspectiva polifônica. Campinas, SP: Editora da UNICAMP, 1996.

BRIDI, Marlise Vaz. Modernidade e Pós-modernidade na Ficção Portuguesa Contemporânea. Todas as Letras: revista de Língua e Literatura. Ano 7, n. 7, edição especial, São Paulo, 2005.

BRITO, Vera Maria de Miranda Leão de. A Personagem e o Tempo. Dissertação (Mestrado em Letras) - Departamento de Letras Clássicas e Vernáculas da Universidade de São Paulo. São Paulo: USP, 2006.

CAMÕES, Luís de. Os Lusíadas (episódios). Apresentação e Notas: Ivan Teixeira. São Paulo: Ateliê Editorial, 2001.

CLARK, Katerina e HOLQUIST, Michael. Mikhail Bakhtin. Trad. de J. Guinsburg. São Paulo: Perspectiva, 1998.

CODO, Wanderley. O que é alienação. 10. ed. São Paulo: Brasiliense, 1995. (Coleção Primeiros Passos; 141) 
COELHO, Nelly Novais. O Corpo-Da-Escrita no Romance Feminino Português. In: IV Congresso Abralic. Anais - Literatura e Diferença. Sao Paulo, 31 de julho, 1, 2 e 3 de agosto, 1994.

EAGLETON, Terry. As ilusões do pós-modernismo. Trad. Elisabeth Barbosa. Rio de Janeiro: Jorge Zahar Ed., 1998.

$\overline{\text { Afrontamento, } 1976 .}$

. Marxismo e Crítica Literária. Trad. Antônio Sousa Ribeiro. Porto: Edições

ELIADE, Mircea. Aspectos do Mito. Trad. Manuela Torres. Lisboa: Edições 70, 1963.

. Imagens e Simbolos: ensaios sobre o simbolismo mágico-religioso. Trad. Sônia Cristina Tamer. São Paulo: Martins Fontes, 1996.

. Mito e realidade. Trad. Pola Civelli. 6. ed. São Paulo: Perspectiva, 2004.

. O Mito do Eterno Retorno. Trad. Manuela Torres. Lisboa: Edições 70, 1969.

FELMAN, Yvonne. Diálogo com a Mulher Portuguesa. In: Salazar Visto do Brasil: antologia de textos de autores brasileiros e portugueses. São Paulo: Editora Felman-Rego, 19?.

FERREIRA, Isabel Alves. Mocidade Portuguesa Feminina. Revista de História das Idéias. Coimbra, vol. 16, 1994.

FIORIN, José Luiz. O Romance e a representação da heterogeneidade constitutiva. In: (Org.) Diálogos com Bakhtin. 3. ed. Curitiba: Editora UFPR.

FRYE, Northrop. Anatomia da Crítica. Trad. Péricles Eugênio da Silva Ramos. São Paulo: Cultrix, 1973.

GIDDENS, Anthony. Modernidade e Identidade. Trad. Plínio Dentzien. Rio de Janeiro: Jorge Zahar Editor, 2002.

GNERRE, Maurizio. Linguagem, Escrita e Poder. São Paulo: Martins Fontes, 1994.

HEGEL, G. W. F. Fenomenologia do Espírito: Parte II. Trad. Paulo Meneses. 4. ed. Petrópolis: Vozes, 1999.

HERMANN, Jaqueline. No Reino do Desejado: a construção do sebastianismo em Portugal século XVI e XVII. São Paulo: Cia das Letras, 1998.

HUTCHEON, Linda. Uma teoria da paródia. Trad. Teresa Louro Pérez. Rio de Janeiro: Edições $70,1985$.

UFMG, 2000.

. Teoria e Política da Ironia. Trad. Julio Jeha. Belo Horizonte: Editora 
JENNY, Laurent. [et al] Intertextualidades. "Poétique”: revista de teoria e análise literárias. Trad. Clara Crabbé Rocha. n. 27, Coimbra, Livraria Almedina, 1979.

JOLLES, André. Formas Simples: legenda, saga, mito, adivinha, ditado, caso, memorável, conto, chiste. São Paulo: Cultrix, 1976.

LIMA, Isabel Pires de. Traços Pós-Modernos na Ficção Portuguesa Actual. Semear - Revista das Cátedra Padre Antônio Vieira de Estudos Portugueses. Rio de Janeiro, n. 4, 2000, p. 9 - 28.

LOPES, Oscar. A Busca de Sentido: questões de literatura portuguesa. Lisboa: Editorial Caminho, 1994.

LOURENÇO, Eduardo. O Labirinto da Saudade: psicanálise mítica do destino português. 3. ed. Lisboa: Gradiva, 2004.

LUKÁCS, Georg. A teoria do romance. Trad. José Marcos Marini de Macedo. São Paulo: Duas Cidades; Ed. 34, 2000.

LYOTARD, J. F.. A condição pós-moderna. Rio de Janeiro: José Olympio, 2000.

MAINGUENEAU, Dominique. O contexto da obra literária: enunciação, escritor, sociedade. Trad. Marina Appenzeller. São Paulo: Martins Fontes, 2001.

MARTINS, Maria Antônia Dias. Literatura Portuguesa de Resistência: a mulher, a guerra e o intelectual como armas de luta contra o salazarismo. Dissertação (Mestrado em História) Departamento de História da Faculdade de Filosofia, Letras e Ciências Humanas da Universidade de São Paulo. São Paulo: USP, 2006.

MENDONÇA, Fernando. O Romance Português Contemporâneo. São Paulo: Faculdade de Filosofia, Ciências e Letras de Assis, 1966.

MESZÁROS, István. Educação contra a alienação. Jornal Brasil de Fato 25/05/2006. Entrevista concedida a João Alexandre Peschanski.

Zahar, 1981.

. Marx: a teoria da alienação. Tradução de Waltensir Dutra. Rio de Janeiro:

MIElietinsKi, E. M.. A Poética do Mito. Trad. Paulo Bezerra. Rio de Janeiro: ForenseUniversitária, 1987.

MOISÉS, Massaud. Dicionário de termos literários. São Paulo: Cultrix, 1988.

MONTEIRO Adolfo Victor Casais. O romance e seus problemas. Lisboa: Livraria Editora da Casa do Estudante do Brasil, 1950.

PAPPENHEIM, Fritz. Alienação do Homem Moderno. Trad. Luiza Sampaio. São Paulo: Editora Brasiliense, 1967. 
PINTASILGO, Maria de Lourdes. O livro esquecido. Visão - Ensaio. 5 de março de 1998, p. 98.

PORTELA, Eduardo. Sobre a Paródia. Revista Tempo Brasileiro. n. 62, Julho-Setembro, 1980.

PROPP, Vladimir I.. Morfologia do Conto Maravilhoso. Trad. Jasna Paravich Sarhan. 4. ed. Rio de Janeiro: Forense Universitária, 1984.

ROCHA, Clara. Ficção dos anos 80. In: História da Literatura Portuguesa: as correntes contemporâneas. Lisboa: Publicações Alfa, 2002.

ROSENFELD, Anatol. Literatura e Personagem. In: CANDIDO, Antônio [et al]. A Personagem de Ficção. 11. ed. São Paulo: Perspectiva, 2005. . Texto / Contexto. São Paulo: Perspectiva, 1969.

ROSENFIELD, Denis L. Hegel. Rio de Janeiro: Jorge Zahar Editor, 2002.

RUTHVEN, K. K. O Mito. Trad. Esther Eva Horivitz de BeerMann. São Paulo: Perspectiva, 1997.

SANTILLI, Maria Aparecida. Fronteiras da liberdade, na ficção das Literaturas de Língua Portuguesa. In:_. Paralelas e Tangentes entre Literaturas de Língua Portuguesa. Coleção Via Atlântica, São Paulo, n. 4, 2003.

SARAIVA, José Hermano. História Concisa de Portugal. 22. ed. Lisboa: Publicações EuropaAmérica, 2003.

SAUSSURE, Ferdinand. Curso de Lingüística Geral. São Paulo: Editora Cultrix, 1994.

SECCO, Lincoln. 25 de Abril de 1974: a Revolução dos Cravos. São Paulo: Companhia Editora Nacional, 2005.

Outubro, 2004.

. Trinta Anos da Revolução dos Cravos. Revista Adusp. n. 33, São Paulo,

SIMÕES, Maria de Lourdes Netto. A ficção que re-escreve a história da fase do recrudescimento da ditadura portuguesa. In: Limites. $3^{\circ}$ Congresso Abralic - Anais, vol. II. São Paulo, Edusp, 1995.

TAVARES, Maria José Ferro. História de Portugal Medievo: economia e sociedade. Lisboa: Universidade Aberta, 1992.

TODOROV, Tzvetan. As Estruturas Narrativas. Trad. Leyla Perrone-Moisés. São Paulo: Perspectiva, 2004.

VECHI, C. A. Sebastianismo: o fracassado mito de origem. Todas as Letras: revista de Língua e Literatura. Ano 5, n. 5, São Paulo, 2003. 
VICENTE, Ana. Do Autoritarismo e das Mulheres Nas Segunda e Terceira Repúblicas. In: Revista de História das Idéias 16. Do Estado Novo ao 25 de Abril. Instituto de História e Teoria das Idéias. Faculdade de Letras. Universidade de Coimbra, 1994. 